\title{
United States: 2003 Article IV Consultation-Staff Report; Staff Supplement; and Public Information Notice on the Executive Board Discussion
}

Under Article IV of the IMF's Articles of Agreement, the IMF holds bilateral discussions with members, usually every year. In the context of the Article IV consultation with the United States, the following documents have been released and are included in this package:

- the staff report for the 2003 Article IV consultation, prepared by a staff team of the IMF, following discussions that ended on June 11, 2003, with the officials of the United States on economic developments and policies. Based on information available at the time of these discussions, the staff report was completed on July 8, 2003. The views expressed in the staff report are those of the staff team and do not necessarily reflect the views of the Executive Board of the IMF.

- $\quad$ a staff supplement of July 29, 2003 updating information on recent developments.

- $\quad$ a Public Information Notice (PIN) summarizing the views of the Executive Board as expressed during its July 30, 2003 discussion of the staff report that concluded the Article IV consultation.

The document(s) listed below have been or will be separately released.

Selected Issues Paper

Report on the Observance of Standards and Codes-Fiscal Transparency Module

The policy of publication of staff reports and other documents allows for the deletion of market-sensitive information.

To assist the IMF in evaluating the publication policy, reader comments are invited and may be sent by e-mail to publicationpolicy@imf.org.

$$
\begin{gathered}
\text { Copies of this report are available to the public from } \\
\text { International Monetary Fund • Publication Services } \\
70019^{\text {th }} \text { Street, N.W. • Washington, D.C. 20431 } \\
\text { Telephone: (202) 623-7430 • Telefax: (202) 623-7201 } \\
\text { E-mail: publications@imf.org • Internet: http://www.imf.org }
\end{gathered}
$$

Price: $\$ 15.00$ a copy

\section{International Monetary Fund Washington, D.C.}




\title{
INTERNATIONAL MONETARY FUND
}

\author{
UNITED STATES OF AMERICA
}

\section{Staff Report for the 2003 Article IV Consultation}

\author{
Prepared by the Staff Representatives for the 2003 Consultation \\ with the United States of America
}

Approved by Anoop Singh and Leslie Lipschitz

July 8, 2003

- The 2003 Article IV discussions took place in Washington, D.C., during May and June. The staff team comprised C. Collyns (Head), C. Towe, M. Mühleisen, R. Cardarelli, C. Faulkner-MacDonagh, I. Ivaschenko, and A. Kose (all WHD); A. Hilaire (PDR); C. Schnure (ICM); and D. Simard (FAD). Ms. Jacklin and Ms. Lundsager, U.S. Executive Director and Alternate U.S. Executive Director, respectively, and Mr. Baukol (Advisor), also attended the meetings.

- The Managing Director, the First Deputy Managing Director, Mr. Rogoff (RES), and Mr. Singh (WHD) took part in the concluding discussions with Treasury Secretary Snow and Federal Reserve Chairman Greenspan. The mission met with officials from the U.S. Treasury, the Federal Reserve, the Department of Energy, the Office of the Comptroller of the Currency, the Council of Economic Advisers, the Office of Management and Budget, the Office of the U.S. Trade Representative, the Congressional Budget Office, the National Governors Association, the Office of Federal Housing Enterprise Oversight, and the Securities and Exchange Commission. The team also met with financial market participants and the Federal Reserve Bank of New York during March.

- The 2002 consultation was concluded in July 2002 (Appendix I). At the time, Executive Directors noted the remarkable resilience of the U.S. economy but stressed the downside risks to the outlook and the importance of policies to support an orderly correction of the large U.S. current account deficit. Accordingly, they encouraged the adoption of a fiscal framework that included the clear goal of balancing the budget excluding Social Security, as well as early steps to place the Social Security and Medicare systems on a sound financial footing. They supported the Federal Reserve's accommodative policy stance, but noted the room for further easing if conditions warranted. Finally, Executive Directors expressed concern regarding agricultural subsidies and safeguard duties on steel imports and urged U.S. leadership in promoting trade liberalization.

- The United States has accepted the obligations of Article VIII, and it maintains an exchange system free of restrictions on payments and transfers for current international transactions (Appendix I). Comprehensive economic data are available for the United States on a timely basis, the United States subscribes to the Fund's Special Data Dissemination Standard, and its metadata are posted on the Fund's Data Standards Bulletin Board (Appendix II).

- The U.S. authorities have participated in a staff review of fiscal transparency and related Report on the Observance of Standards and Codes. 
Contents

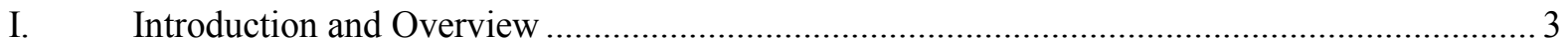

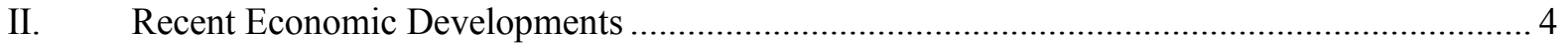

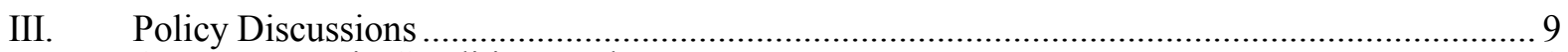

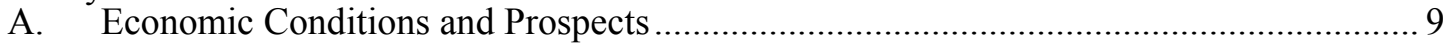

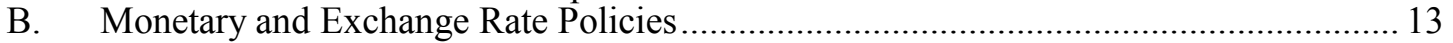

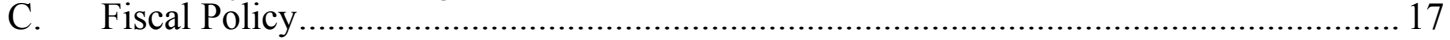

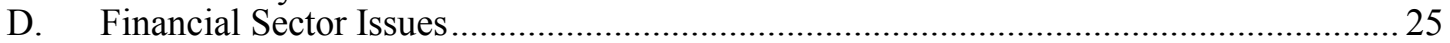

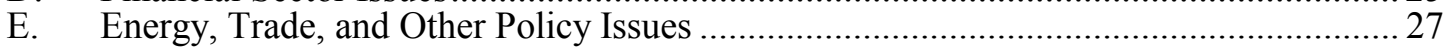

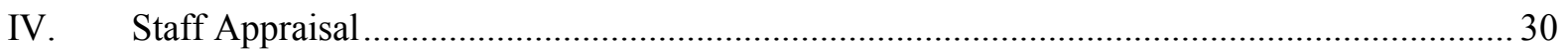

Boxes

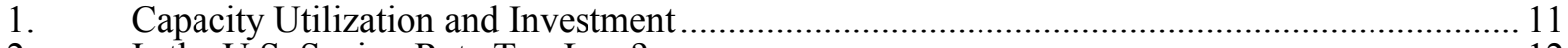

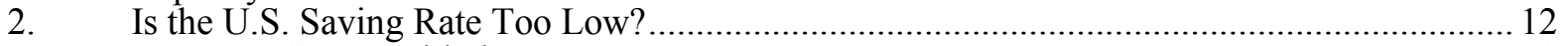

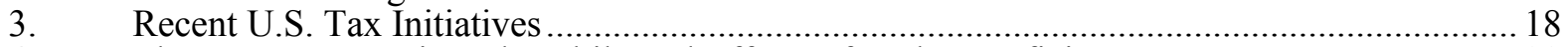

4. The Macroeconomic and Multilateral Effects of Budget Deficits............................................ 22

5. Fiscal Transparency in the United States ........................................................................ 23

6. U.S. Macroeconomic Developments and Trade Policies-Multilateral Implications ................ 29

Tables

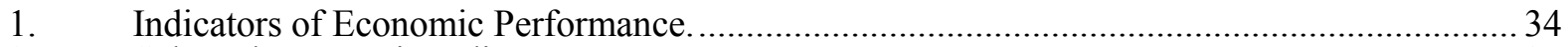

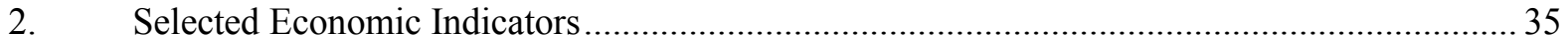

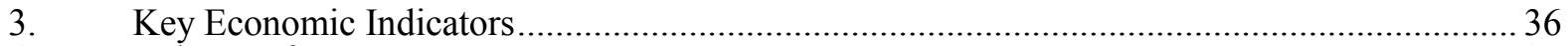

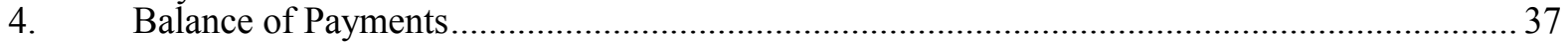

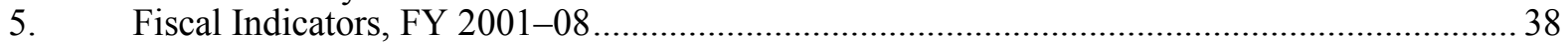

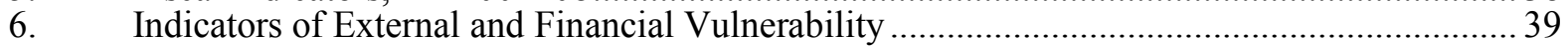

Figures

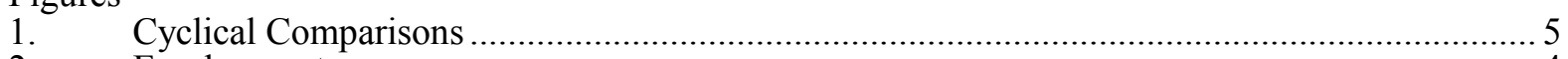

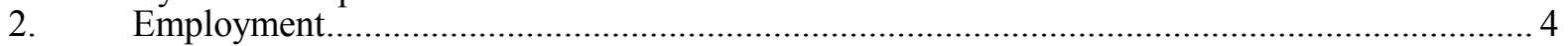

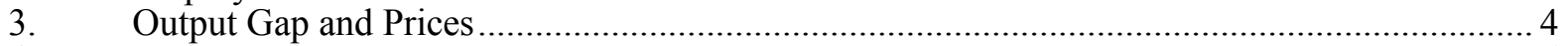

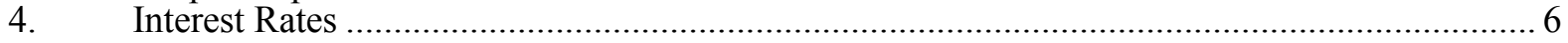

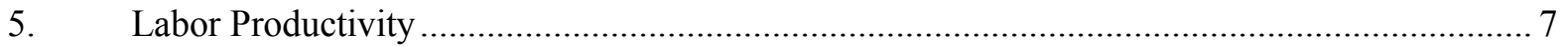

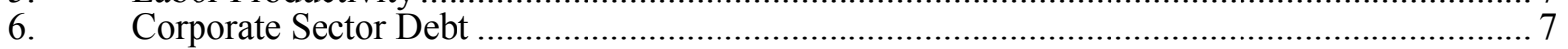

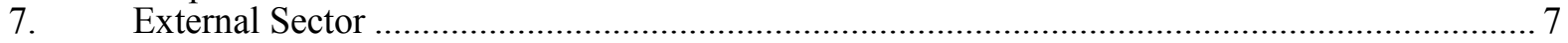

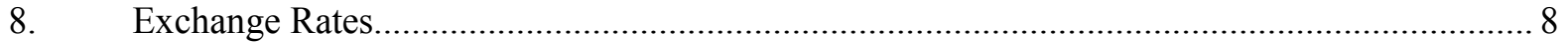

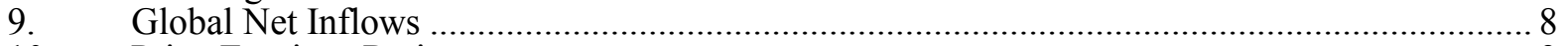

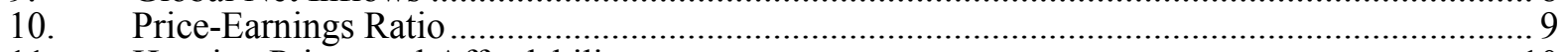

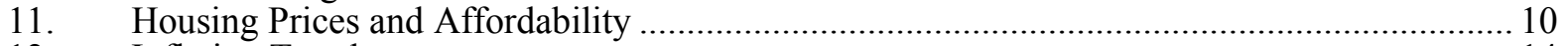

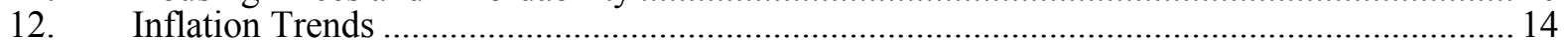

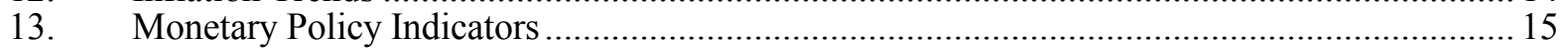

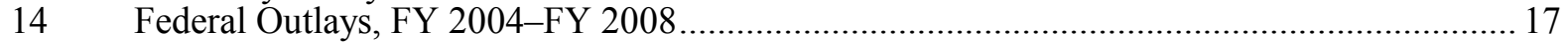

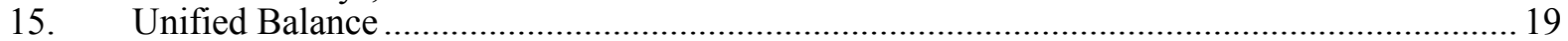

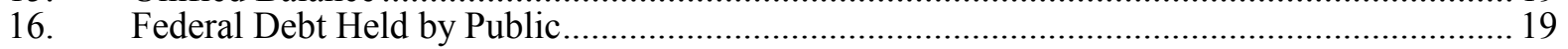

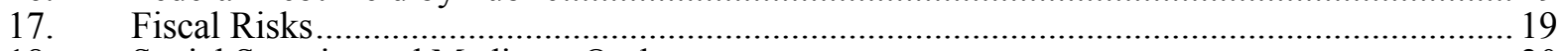

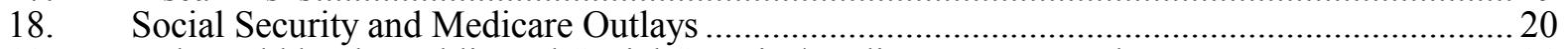

19. Debt Held by the Public and Social Security/Medicare Trust Funds ...................................... 21

20. Health Expenditures and Life Expectancy in OECD Countries.............................................. 25

Appendices

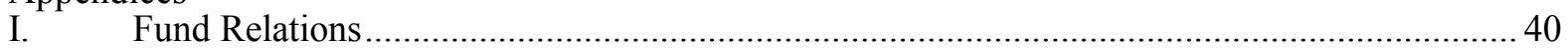

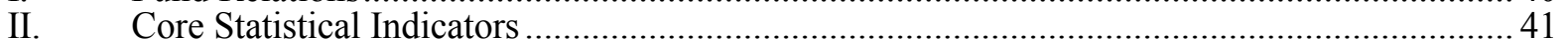

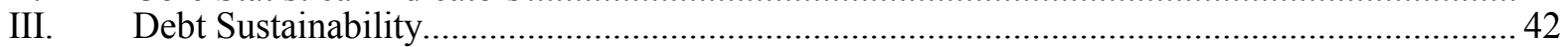




\section{INTRODUCTION AND OVERVIEW}

1. The 2003 consultation took place against the backdrop of heightened uncertainty about the strength of the recovery. After experiencing one of the largest stock market declines in the post-war period and then falling into recession in early 2001, the economy was buffeted by a series of further shocks, including the September $11^{\text {th }}$ attacks, major corporate failures, additional stock price declines, and the war in Iraq. Remarkably, productivity growth has remained robust; the rise in the unemployment rate has been relatively modest; and large corporate bankruptcies were absorbed without a systemic impact on financial intermediaries. Nevertheless, the recovery has been uneven and sluggish.

2. The weak economy and security concerns have overshadowed policy making and significantly undermined the fiscal position. Despite an aggressive easing of monetary policy, economic slack has increased and deflation has now become a concern. On the fiscal front, the policy focus has been on tax cuts, fiscal stimulus, and-since the September $11^{\text {th }}$ attacks - boosting security-related spending. As a result, the fiscal surpluses that were achieved over the course of the 1990s have given way to large deficits, complicating the task of dealing with impending demographic pressures.

3. Against this background, discussions centered on:

- Managing short-term risks. With the substantial deterioration in the fiscal outlook, and inflation low, monetary policy should bear the principal responsibility to respond if the recovery does not regain momentum.

- $\quad$ Re-establishing a sustainable fiscal framework. The additional stimulus introduced this year leaves the fiscal position even less well prepared to cope with impending demographic pressures. The priority remains to establish a credible framework for delivering a balanced budget, excluding Social Security, over the medium-term and to place retirement and health care systems on a sound financial footing.

- International perspectives. The U.S. economy has helped support global growth in recent years, but the eventual correction of imbalances related to large fiscal and current account deficits could impose costs on the rest of the world. On trade issues, strong U.S. leadership is needed toward forging deep and broad-based liberalization in the Doha Round.

4. U.S. officials remarked that U.S. policies had been broadly consistent with Fund advice over the years, which mainly reflected a shared philosophy about the importance of sound and market-oriented policies. Differences of view remained, however. While the authorities had broadly agreed last year with the staff on the need for medium-term fiscal consolidation, the weak economy and national security had been seen as more immediate priorities. The authorities did not share the staff's long-standing concern regarding the U.S. current account deficit, which they considered mainly a reflection of weak growth abroad and, therefore, not a U.S. policy matter. Although staff has expressed some specific concerns in recent years regarding U.S. trade actions, officials emphasized the overall U.S. commitment to multilateral trade liberalization. 


\section{RECENT ECONOMIC DEVELOPMENTS}

5. Following a relatively shallow downturn in 2001, the economy has staged an uneven recovery (Tables 1,2 , and 3 ). Despite a massive collapse of equity prices and business investment, the 2001 recession was mild and short-lived, with output dropping by only $1 / 2$ percent in the first three quarters. Thereafter, a series of shocks began to weigh on activity, including: the

September $11^{\text {th }}$ attacks; major accounting scandals and business failures; further declines in stock prices; and geopolitical uncertainty and higher oil prices during the run-up to the Iraq war. As a result, the recovery has been lackluster, and growth slowed again to an annualized rate of $1 \frac{1 / 4}{4}$ percent during 2002Q4-2003Q1 (Figure 1).

\begin{tabular}{|c|c|c|c|c|c|c|}
\hline \multicolumn{7}{|c|}{$\begin{array}{l}\text { United States: Selected Indicators of Economic Activity } \\
\text { (Percent change from previous period, unless otherwise indicated) }\end{array}$} \\
\hline & \multirow[t]{2}{*}{2002} & \multicolumn{4}{|c|}{2002} & \multirow{2}{*}{2003} \\
\hline & & Q1 & Q2 & Q2 & Q4 & \\
\hline Real GDP growth & 2.4 & 5.0 & 1.3 & 4.0 & 1.4 & 1.4 \\
\hline Final domestic demand & 2.4 & 3.0 & 1.3 & 3.3 & 2.6 & 1.4 \\
\hline Private consumption & 3.1 & 3.1 & 1.8 & 4.2 & 1.7 & 2.0 \\
\hline Business fixed investment & -5.7 & -5.8 & -2.4 & -0.8 & 2.3 & -4.4 \\
\hline Residential investment & 3.9 & 14.3 & 2.6 & 1.0 & 9.4 & 10.1 \\
\hline Inventories $1 /$ & 0.6 & 2.6 & 1.3 & 0.6 & 0.3 & -0.8 \\
\hline Net exports $1 /$ & -0.6 & -0.8 & -1.4 & 0.0 & -1.6 & 0.8 \\
\hline Unemployment rate (percent) & 5.8 & 5.6 & 5.8 & 5.8 & 5.9 & 5.8 \\
\hline Current account balance 2/ & -4.6 & -4.1 & -4.7 & -4.7 & -4.9 & -5.1 \\
\hline $\begin{array}{l}\text { Source: Haver Analytics. } \\
\text { 1/ Contribution to growth. } \\
\text { 2/ As a share of GDP. }\end{array}$ & & & & & & \\
\hline
\end{tabular}

\section{As a result of slow} growth, employment has stagnated, economic slack has continued to rise, and inflation has fallen to near postwar lows. Private nonfarm payrolls remained $23 / 4$ percent below their early 2001 peak in June 2003. The unemployment rate rose sharply from a 30 -year low of just under 4 percent in early 2000 , but remained in the $5 \frac{1 / 2}{-}$ 6 percent range during most of 2002 and early 2003. However, the unemployment rate jumped to $6 \frac{1}{4}$ percent in June.

(Figure 2). Although strong productivity growth in recent years has left measures of potential output subject to considerable uncertainty, most estimates suggest the output gap widened to around $2 \frac{1}{2}$ percent in early 2003 (Figure 3). With slack increasing, the core CPI inflation rate has trended downward to under $1 \frac{1}{2}$ percent, a level not seen since the mid-1960s.
Figure 2. United States: Employment

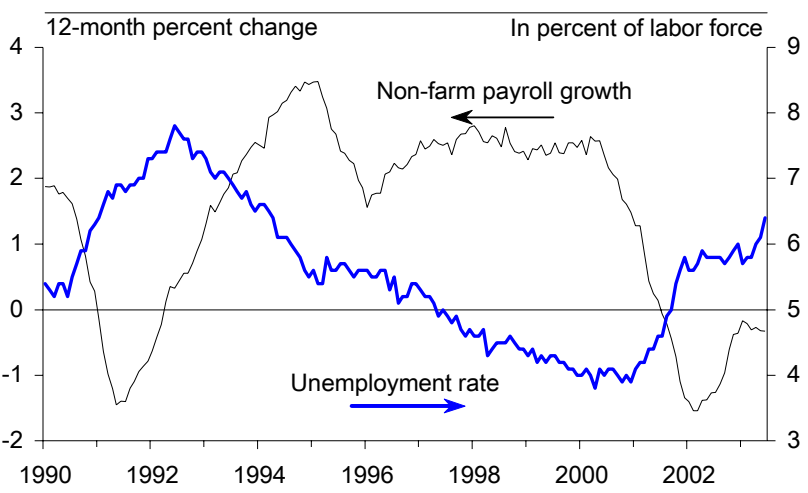

Figure 3. United States: Output Gap and Prices

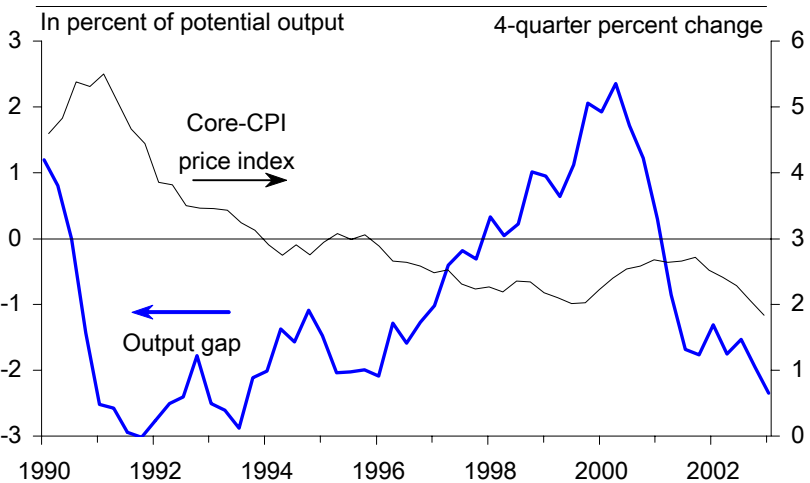


Figure 1. United States: Cyclical Comparisons 1/
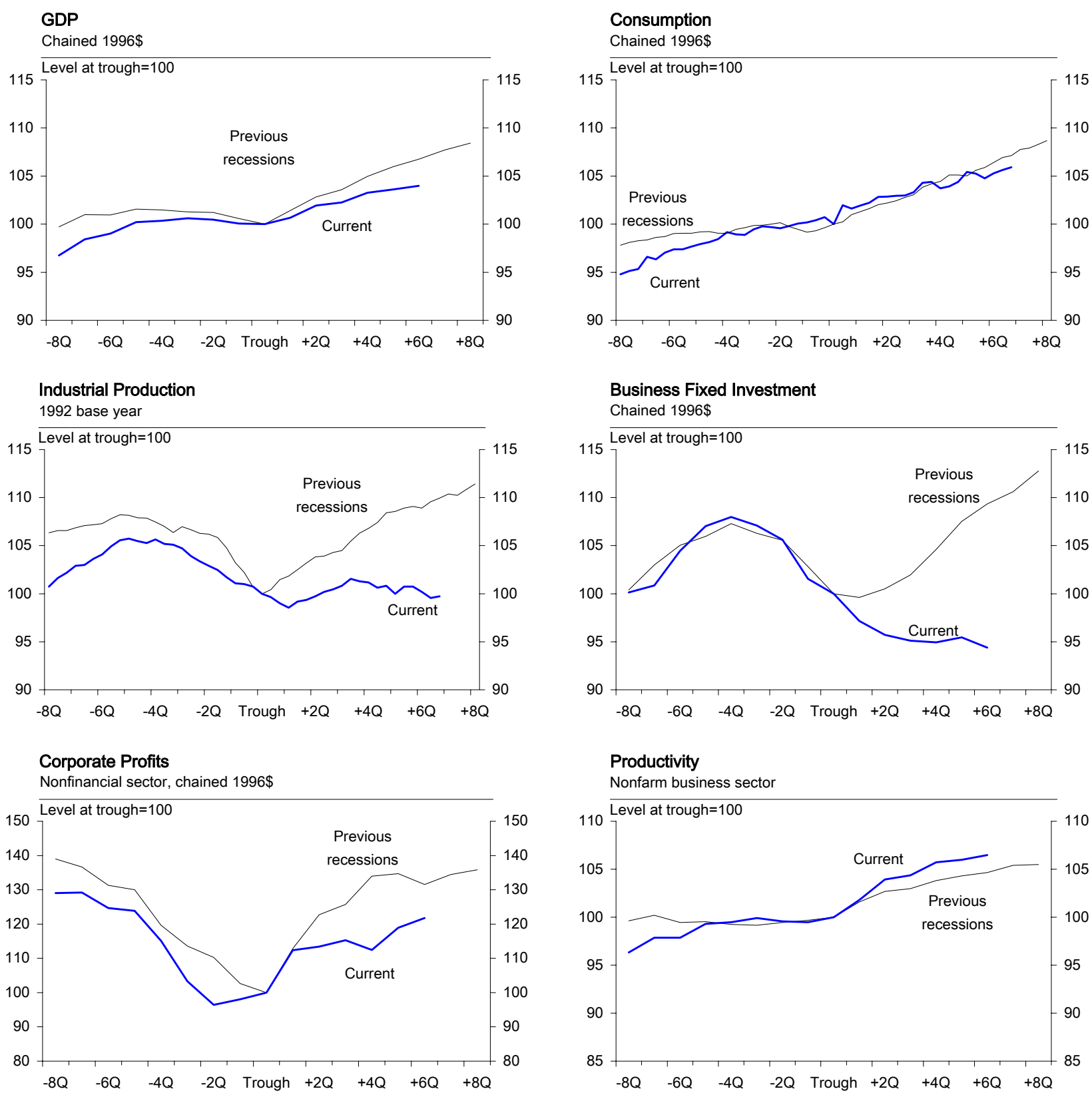

Stock Prices

S\&P 500, monthly average
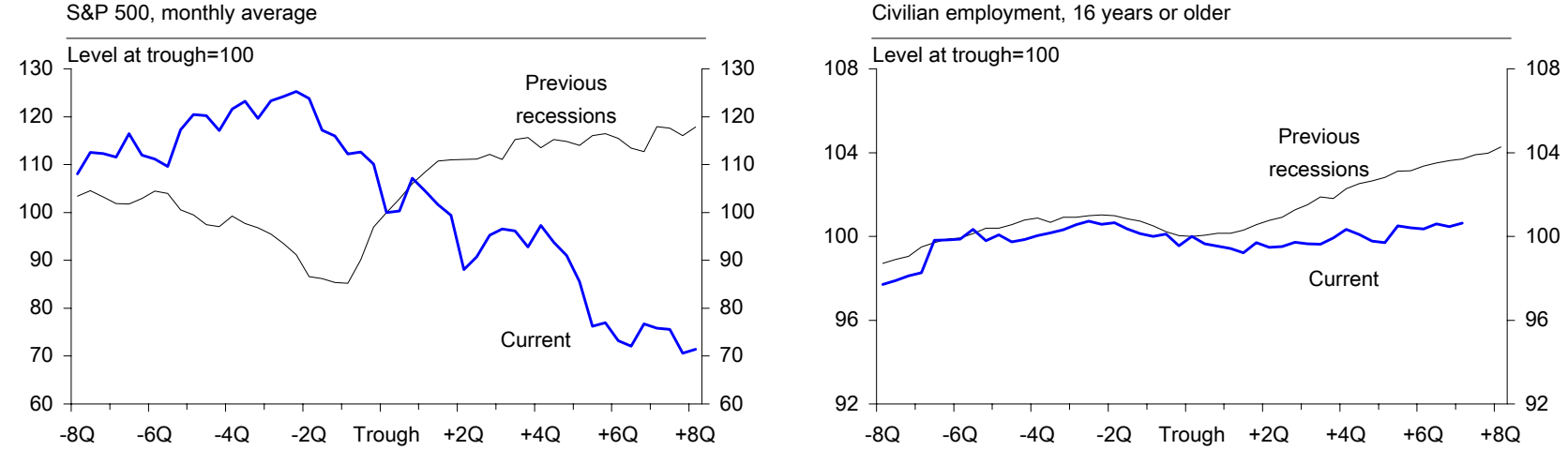

1/ Previous recessions defined as the average level during the December 1969, November 1973, January 1980, July 1980, July 1990, and March 2001 recessions, normalized to 100 at the trough, as defined by the National Bureau of Economic Research. The trough of the 2001 recession is assumed to be $2001 \mathrm{Q} 3$. 
7. The economy's recent loss of momentum occurred despite exceptional support from monetary and fiscal policies. Although the dollar's strength and the drop in stock prices have weighed on indicators of financial conditions, monetary easing has been unprecedented. The federal funds rate target was reduced by a cumulative 475 basis points during 2001, a further 50 basis points in November 2002, and an additional 25 basis points in June 2003. As a result, long-term bond yields have fallen close to post-war lows (Figure 4). On the fiscal front, substantial reductions in income tax rates were legislated in June 2001; March 2002 legislation increased investment incentives and extended unemployment benefits; defense and security-related spending was increased significantly in 2002 and 2003; and substantial additional tax cuts were legislated in May 2003. These measures contributed to a massive shift in the federal government's unified budget from a surplus of $2 \frac{1}{2}$ percent of GDP in FY 2000 (October-September) to a deficit likely to reach almost 4 percent of GDP in FY 2003, a 5 percentage point turnaround in structural terms.

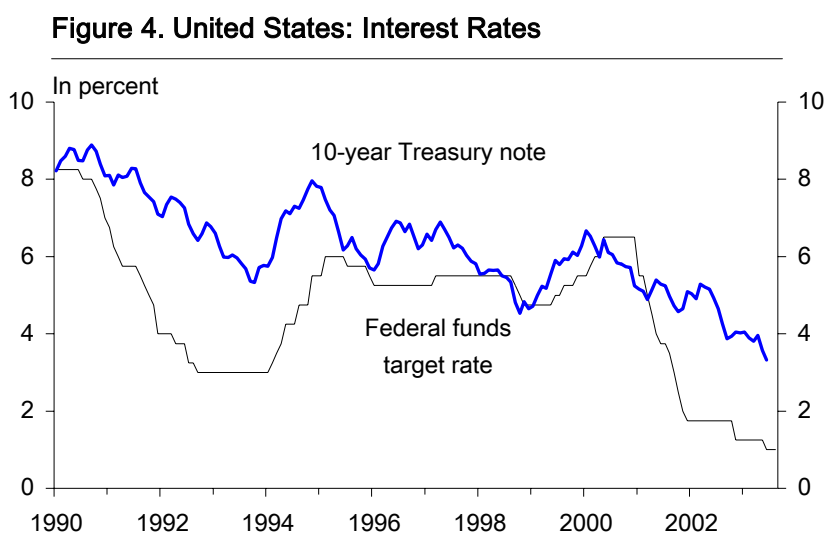

\section{Private consumption has remained remarkably resilient, owing to income gains,} low interest rates, and the housing market boom. During the two years ending May 2003, real disposable income rose by $7 \frac{1}{4}$ percent, over half of which reflected tax cuts and higher unemployment benefits. In addition, productivity gains facilitated strong growth of labor incomes, as hourly wage increases more than offset employment declines. Lower mortgage rates and higher home prices prompted record refinancing, which reduced interest payments and freed up home equity for consumption and debt repayment. ${ }^{1}$ Discounting by auto and other manufacturers also mitigated the effects of higher energy prices. As a result, households managed to maintain consumption, spur strong growth in residential investment, and still boost their saving rate from 2 percent in mid-1999 to around 31/2 percent in early 2003.

9. By contrast, the recovery in business fixed investment has been tentative. Purchases of equipment and software plummeted from historical highs relative to GDP during 2000-01, but began to recover in the last three quarters of 2002, supported by a rebound in profits and the replacement of IT equipment purchased ahead of Y2K. Through much of 2002, inventory restocking also provided a substantial boost to activity. However, confidence in the underlying strength of investment demand was dampened by a renewed drop in business equipment and software purchases in the first quarter of 2003, and a sharp increase in industrial vacancy rates continued to weigh on nonresidential structures investment.

\footnotetext{
${ }^{1}$ The Federal Reserve estimates that mortgage refinancing allowed homeowners to "cash out" approximately $\$ 200$ billion (2 percent of GDP), around one half of which was used to pay down other forms of debt.
} 
10. Weak investment has reflected the uncertain strength of corporate profits and balance sheets. Profits began to recover in early 2002, spurred by a $4 \frac{3}{4}$ percent surge in productivity - the fastest annual rate in over 50 years - and a concomitant 2 percent decline in unit labor costs (Figure 5). Cash flows also benefited from lower interest rates and investment incentives introduced in March 2002. However, the investment rebound has been considerably weaker than in past recoveries, and profit growth has been disappointing, partly owing to a sharp rise in pension and health care costs. Default rates on commercial bank lending have eased somewhat, but remain elevated, and corporate debt remains close to nearly 50 percent of GDP (Figure 6).

\section{Some sectors suffer} particularly severely from high debt loads, long-standing structural problems, and declining output prices. Cash flows in the auto, industrial machinery, and steel-using (fabricated metals) industries remain particularly weak, and significant losses have been registered in the transportation and communications sectors. In many of these industries, employee defined-benefit pension plans are also severely underfunded, and increased employer contributions have further dampened profit growth.

\section{Weak demand abroad and the} earlier strength of the U.S. dollar represented an additional drag on the recovery. Export volumes began to recover modestly in 2002 from their
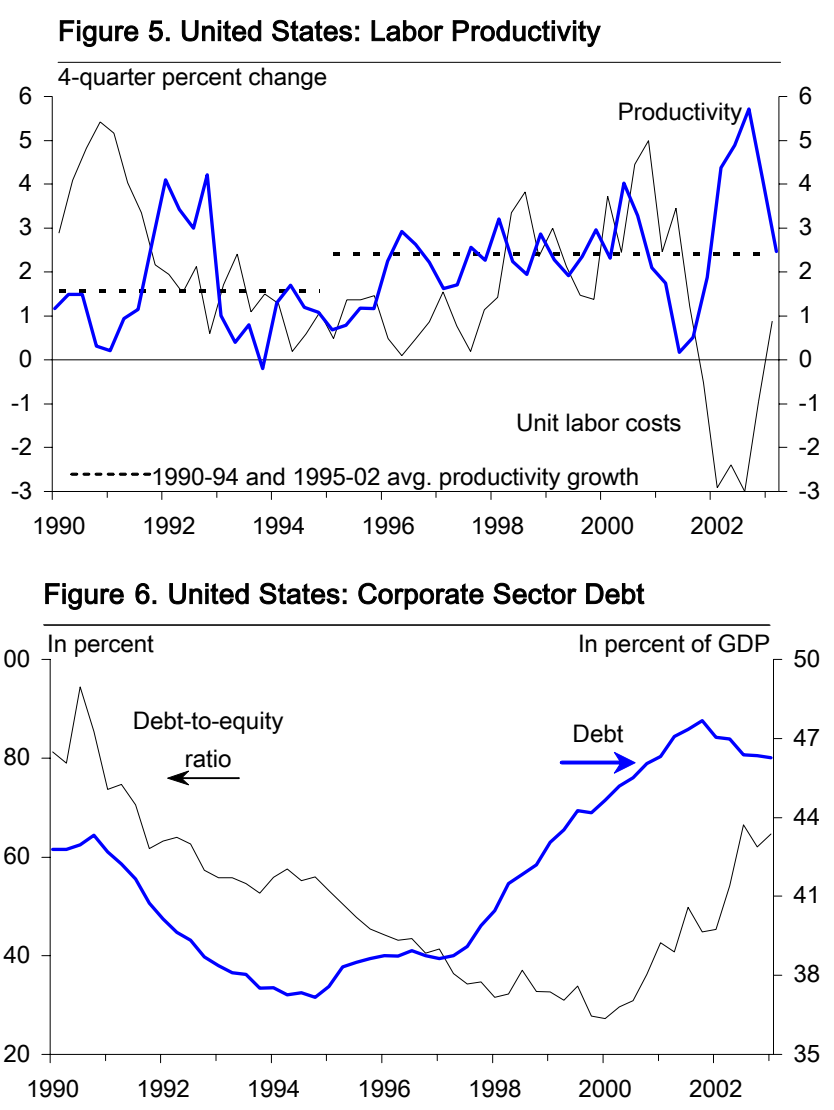

Figure 7. United States: External Sector

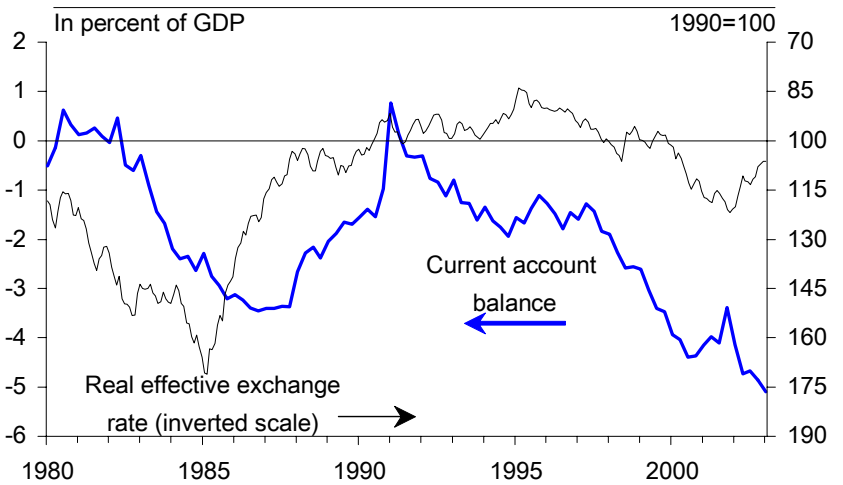
sharp decline in preceding years, but fell again toward the end of the year and in early 2003. Capital goods exports were particularly weak owing to sluggish investment abroad. By contrast, import volumes rebounded strongly in 2002, reflecting purchases of consumer goods and industrial supplies, before dipping in 2003Q1. With higher world oil prices, the current account deficit reached a record 5 $1 / 4$ percent of GDP in 2003Q1 (Figure 7 and Table 4). 


\section{Investor concerns regarding} the U.S. trade imbalance and interest rate differentials have weighed on the dollar since early 2002 (Figure 8).

After appreciating by 30 percent in real effective terms during 1999-2001, the dollar has weakened sharply against the euro and Japanese yen from February 2002 (Figure 8). In real effective terms, the decline was more moderate - around 10 percent to early June 2003 - since the dollar remained strong vis-à-vis Latin American and Asian currencies. As a result, staff estimates suggest that the dollar is still some 20 percent above levels consistent with medium-term fundamentals. $^{2}$

14. The dollar's decline has been associated with a drop in private capital inflows for purchases of corporate securities and direct investment. However, increased purchases of dollar reserves by foreign central banks and lower U.S. investments abroad helped finance the large current account deficit (Figure 9). The U.S. net foreign liability position reached 23 percent of GDP by end-2002, from under 5 percent of GDP in the early 1990 s.

15. The increased risk aversion that weighed on bond and equity markets in 2002 and early 2003 appears to have lifted (Figure 10). In 2002, stock prices fell sharply on news of the collapse of

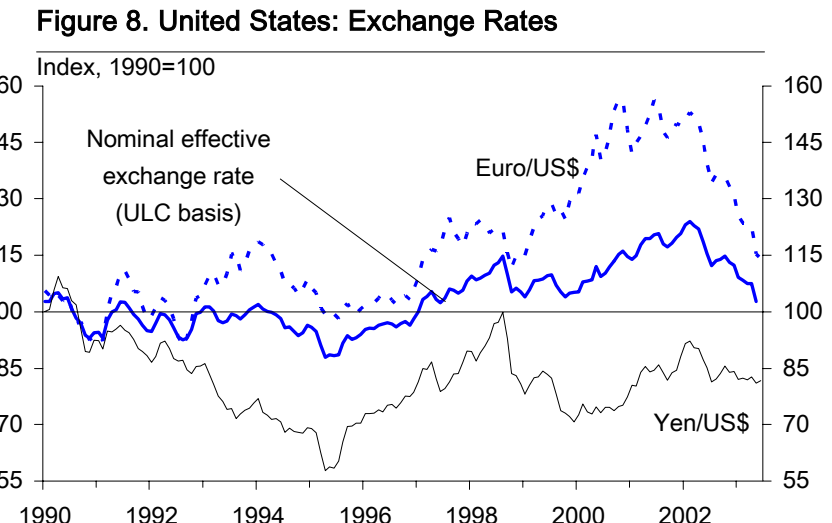

Figure 9. United States: Global Net Inflows

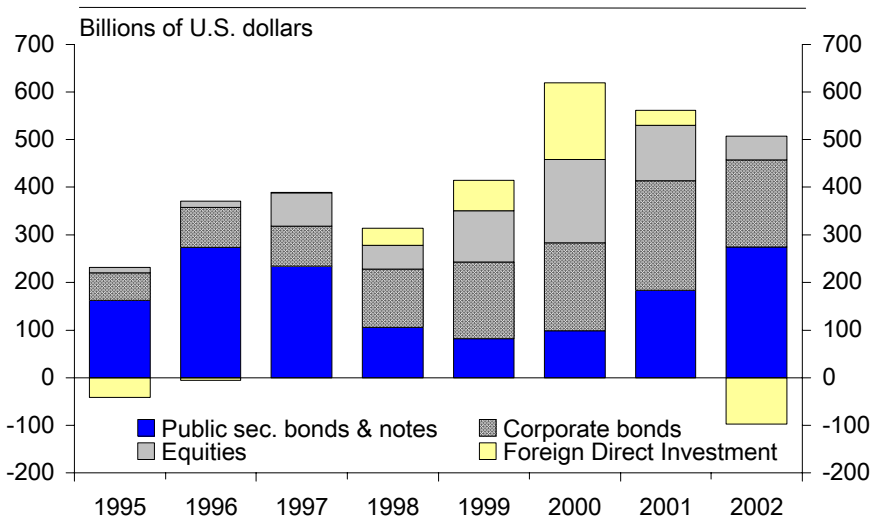

Figure 10. United States: Price-Earnings Ratio

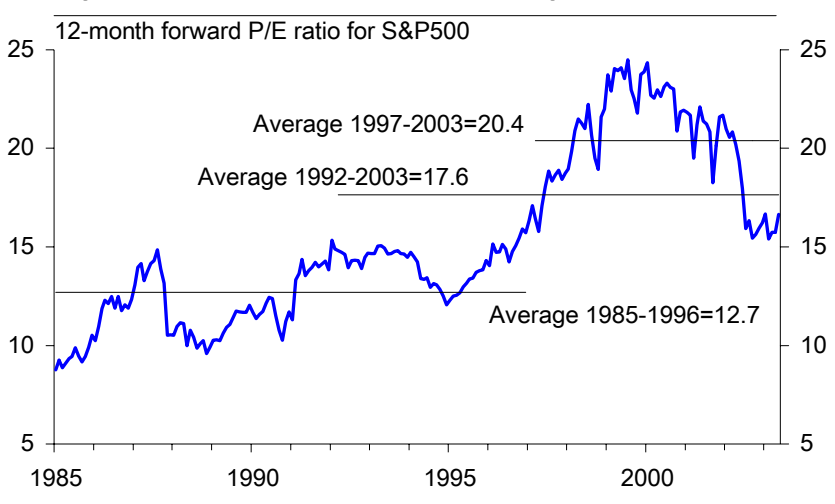

2 CGER assessments in early 2003 suggested that a real effective depreciation of the U.S. dollar of well over 20 percent would be required to reduce the U.S. current account deficit to 2 percent of GDP, a level consistent with the equilibrium saving-investment balance. Purchasing power parity-based estimates yielded similar levels of misalignment. However, the dollar's depreciation in recent months, and the significant decrease in public saving that is now projected, have narrowed the degree of overvaluation. 
Enron and WorldCom and a scaling back of profit forecasts, and corporate bond spreads widened. Market sentiment remained weak in the run-up to the Iraq war, but has since improved considerably. The S\&P 500 index rose by nearly 15 percent during April-May, and spreads have narrowed significantly since the beginning of 2003. With U.S. stock prices roughly 35 percent below their early 2000 peak, valuations now appear broadly in line with historical norms.

\section{Policy Discussions}

\section{A. Economic Conditions and Prospects}

16. The staff projects activity to gather momentum in the latter half of 2003, with GDP growth rising from around 21/4 percent in 2003 to $31 / 2$ percent in 2004. Consumer sentiment has improved with the quick end to the Iraq war, and household demand would also be supported by additional tax cuts, the rebound in stock prices, low interest rates, and the easing of oil prices. These same factors, as well as strong productivity growth, are also expected to allow profits and business fixed investment to gather momentum into 2004. The drag from net exports would wane into 2004, reflecting a gradual strengthening in partner countries and the lagged effects of the dollar's depreciation, and the current account deficit would start to narrow somewhat from around 5 percent of GDP in 2003. With economic slack remaining significant, CPI inflation is projected to fall to around 1 1/4 percent in 2004, before rebounding somewhat as the output gap closes.

\section{The mission agreed} that the longer-term growth potential of the U.S. economy remained strong. Federal Reserve officials considered that labor productivity gains since the downturn only partly reflected labor shedding and efforts by businesses to cut costs. The economy's performance of recent years provided ample evidence that

\begin{tabular}{|c|c|c|c|c|c|c|c|}
\hline \multicolumn{8}{|c|}{$\begin{array}{l}\text { Medium-Term Projections } \\
\text { (Percent change from previous period, unless otherwise indicated) }\end{array}$} \\
\hline & 2002 & 2003 & 2004 & 2005 & 2006 & 2007 & 2008 \\
\hline Real GDP growth & 2.4 & 2.2 & 3.6 & 3.9 & 3.8 & 3.6 & 3.2 \\
\hline Total domestic demand & 3.0 & 2.4 & 3.5 & 3.6 & 3.8 & 3.6 & 3.1 \\
\hline Private consumption & 3.1 & 2.4 & 2.7 & 3.0 & 3.6 & 3.6 & 2.9 \\
\hline Private fixed investment & -3.1 & 1.2 & 3.8 & 4.9 & 5.1 & 5.1 & 5.2 \\
\hline Net exports (contribution) & -0.6 & -0.3 & -0.1 & 0.1 & -0.1 & -0.1 & 0.0 \\
\hline Unemployment rate & 5.8 & 6.0 & 5.8 & 5.5 & 5.4 & 5.3 & 5.3 \\
\hline CPI inflation & 1.6 & 2.1 & 1.3 & 2.1 & 2.5 & 2.5 & 2.5 \\
\hline Unified federal balance/GDP & -1.5 & -4.0 & -4.0 & -2.4 & -1.9 & -1.8 & -1.8 \\
\hline Current account balance/GDP & -4.6 & -5.1 & -4.9 & -4.4 & -4.3 & -4.2 & -4.0 \\
\hline \multicolumn{8}{|l|}{ Memorandum items: } \\
\hline Partner country growth & 2.1 & 2.0 & 3.1 & 3.4 & 3.4 & 3.4 & 3.4 \\
\hline Oil prices (\$/Barrel) & 25 & 27 & 24 & 21 & 21 & 21 & 21 \\
\hline
\end{tabular}
the efficiency gains of the 1990s were not illusory. In their view, consensus estimates of U.S. long-term productivity potential of $2-2 \frac{1}{2}$ percent could be conservative.

18. Discussions focused on the tenuous nature of the short-term recovery. Treasury officials agreed that 2003 growth was likely to be less than the 3 percent rate assumed in the FY 2004 Budget and closer to the staff's projection. The weaker outlook reflected the economy's difficulty in working off the combined effect of the collapse of equity prices and the shock to confidence from the corporate scandals of 2001-2002. Although low interest 
rates, the drop in oil prices, higher defense spending, and recent tax cuts were expected to provide a substantial lift to activity, more subdued scenarios could not be ruled out. ${ }^{3}$

\section{Treasury and Federal Reserve officials agreed that business fixed investment} represented the principal risk to the outlook. Most studies suggested that only a modest capital overhang had emerged at the beginning of the downturn, but other factors appeared to have weighed on investment including: high levels of excess capacity, geopolitical uncertainties and its impact on risk-taking, rising health care and energy costs, and the need to fund defined benefit plans (Box 1). Although credit conditions and corporate balance sheet restructuring favored a strong rebound of investment, a sustained improvement in business confidence and profits was also needed.

20. Officials viewed the risks to household demand as more modest. The strength of consumption through the downturn was broadly consistent with low interest rates, strong wage growth, the surge in housing prices, and tax cuts. Household balance sheets did not exhibit signs of stress - delinquency rates were modest and debt service burdens were not excessive. The personal saving rate had already responded to the decline in household net wealth, and further adjustments were likely to be gradual (Box 2).

21. While recognizing that housing prices were showing signs of overheating, officials discounted the possibility of a collapse. Some urban areas had seen rapid growth in market values, and prices were at the upper end — or even somewhat above — of ranges consistent with underlying fundamentals (Figure 11). ${ }^{4}$ However, the housing market was considered to be relatively insulated from speculative excess; loan-to-value ratios remained comfortable; households were locking in mortgages at low, long-term rates; and market turnover appeared orderly. While the rate of price increase would likely slow in the near future, outright declines were a low probability, except possibly in selected markets. Although an upturn in longterm interest rates posed risks to the housing market, such an event would most likely occur in the context of a broader improvement in economic activity that would provide offsetting support to the market.

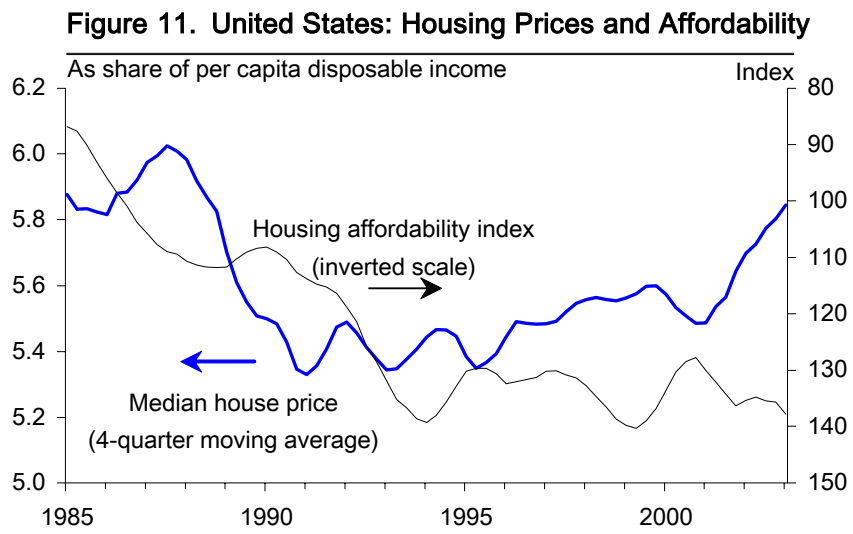

\footnotetext{
${ }^{3}$ See the forthcoming Selected Issues paper for an analysis of the impact of energy price shocks.

${ }^{4}$ Although some recent research—surveyed in the forthcoming Selected Issues paper—suggests that housing prices could be as much as 10-15 percent higher than justified by market fundamentals, most analysts suggest that prices are more likely to slow rather than decline outright.
} 


\section{Box 1. Capacity Utilization and Investment}

The U.S. capacity utilization rate declined sharply during 2001 and has yet to show convincing signs of a turn-around. Moreover, while some other measures of economic slack — such as the unemployment rate - have fared better than in previous cyclical downturns, capacity utilization in the current recession remains considerably lower than in many past recessions, with the exception of the early 1980s.

The dispersion of capacity utilization rates across industries has also been high. Presently, the rate ranges from the low $60 \mathrm{~s}$ in the high-tech industries to the high $80 \mathrm{~s}$ in the petroleum and coal industries. Measured in terms of a weighted standard deviation, the dispersion across industries has reached levels not seen since the early 1980 s.

\section{These developments have raised the question} whether the low level of capacity utilization will weigh on investment going forward. In particular, a number of analysts have argued that firms are unlikely to invest in plant and equipment until capacity constraints become more pressing.

\section{Simple statistical analysis does suggest that} capacity utilization influences future investment. The correlation between investment and the capacity utilization rate (with lags of up to four quarters) is in the range of 0.4 , and simple bivariate tests also suggest that capacity utilization does "Grangercause" growth in investment but not the reverse.

Although these results raise doubts about the likely strength of investment spending in the near term, there are offsetting considerations. The statistical relationship between capacity utilization and investment is usually considered to reflect the impact of other factors, including profits and other growth indicators. Moreover, most analyses suggest the absence of a significant capital overhang. The business sector capital/output ratio (including equipment and structures) declined for most of the 1990 s, and at just over 120 percent at the end of 2001 , is below the average of the last half century. Staff estimates indicate that while a modest overhang in computer equipment emerged at the end of the 1990s, this would have been absorbed relatively quickly, given the recent drop in investment and the rapid depreciation rates of this type of equipment. ${ }^{1}$ Moreover, the average age of equipment in the manufacturing sector, remains relatively high - at 8.3 years for equipment and software. Finally, the industrial sector only accounts for about 17 percent of GDP, so that industrial capacity utilization rates do not necessarily reflect developments in the broader U.S. economy.
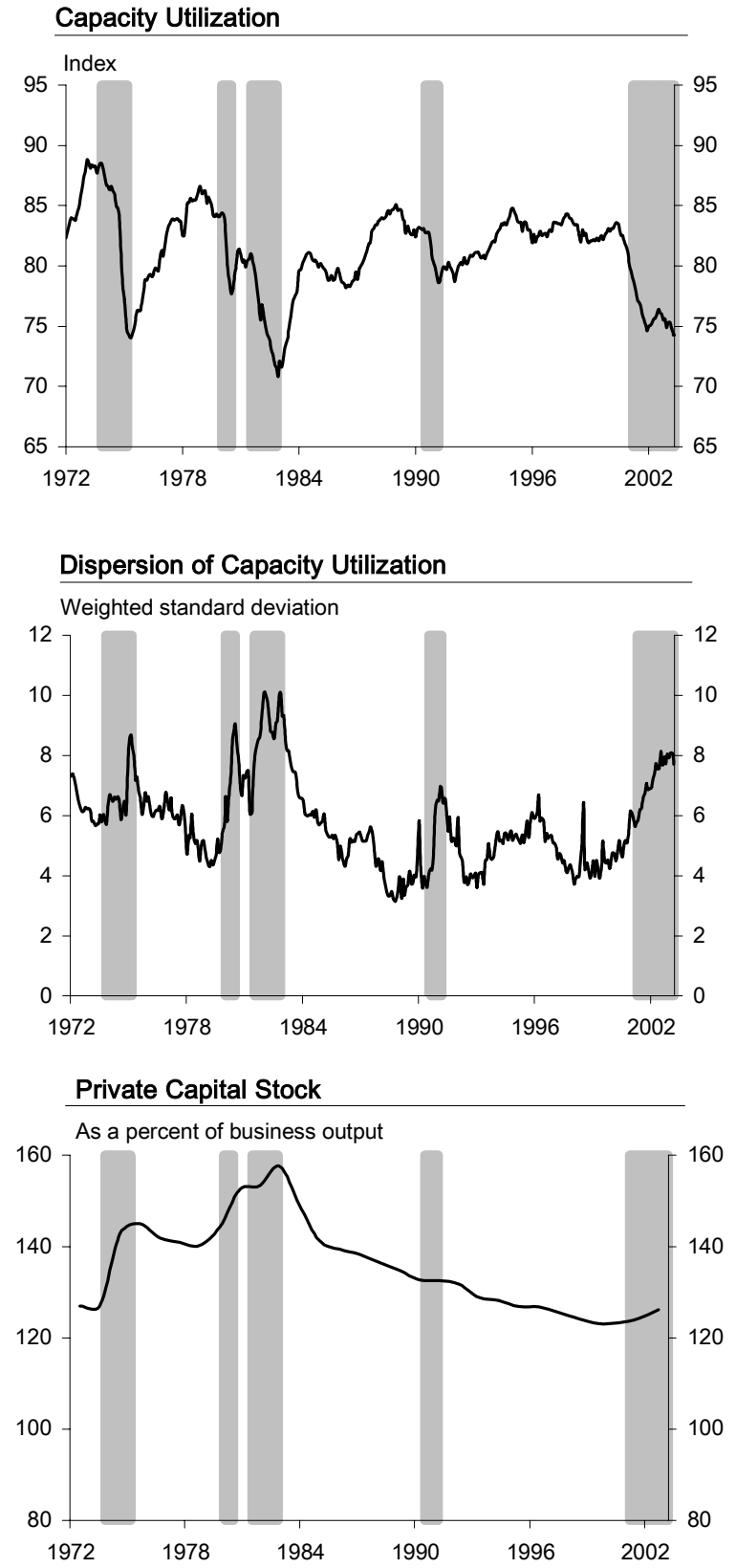

${ }^{1}$ C. MacDonagh-Dumler, "Evaluating the Evidence of a Capital Overhang in the U.S. Economy," United States: Selected Issues, Country Report No. 2/165 (August 2002). 


\section{Box 2. Is the U.S. Saving Rate Too Low?}

U.S. household wealth has fallen significantly since 2000, raising concerns that household demand may be withdrawn in order to restore savings. Household net worth has fallen sharply between 2000 and 2003 - by approximately $\$ 4$ trillion, or 9 percent. Casual inspection of the relationship between the saving rate and household net worth suggests that a decline in wealth of this magnitude would lead to an increase in personal saving of around 4 percentage points. The actual rise in the saving rate has been much more modest, however-less than 2 percentage points, from 2 percent in 2000Q1 to around 31/2 percent in 2003 Q1.

The slow pickup in saving so far can be partly explained by a different response of saving to the accumulation of different types of wealth. A long-run model of consumption, income, and wealth was estimated-where wealth was measured in three categories: housing, equity, and non-equity financial wealth (demand deposits, bonds, and other forms of liquid wealth). ${ }^{1}$ The results suggest that saving is about 3-4 times more responsive to changes in non-equity financial wealth than to changes in either residential or equity wealth. This higher responsiveness may be due to the more liquid nature of non-equity wealth, which means that it can be drawn down quickly, if needed.

Model predictions suggest that the personal saving rate is only about $3 / 4$ percentage points below its estimated equilibrium level. While equity wealth fell by around $\$ 81 / 4$ trillion between 2000-2003, housing wealth rose by about $\$ 3 \frac{1}{4}$ trillion, and nonequity financial wealth increased by $\$ 2 \frac{1}{2}$ trillion. Deposits and money market mutual funds accounted for much of the growth in non-equity financial wealth, as the stock market decline led households to redirect savings into less risky assets and to attempt to lock in capital gains. As a result, the long-run equilibrium saving rate was estimated to be about $4 \frac{1}{2}$ percent in 2003Q1, only modestly above the actual saving rate of $3 \frac{1}{2}$ percent.

However, more abrupt adjustments to the saving rate cannot be ruled out. For example, if the economy were to falter, asset classes that have, to date, dampened losses in the equity market - especially residential housing - could come under pressure. Moreover, the model partly explains the decline in the U.S. saving rate over the past decade in terms of a trend decline, likely reflecting financial innovation, and it remains to be seen whether this trend will be sustained. ${ }^{2}$

\footnotetext{
${ }^{1}$ See the Selected Issues paper for details.
}

${ }^{2}$ Financial innovation was seen as an important contributor to the decline in the personal saving rate in previous staff work. See Cerisola, M. and P. De Masi, 1999, "Determinants of the U.S. Personal Saving Rate," United States-Selected Issues, IMF Staff Country Report No. 99/101. 
22. Officials acknowledged that state and local governments were under significant fiscal stress, which was likely to act as a further drag on activity. ${ }^{5}$ Most states were facing a third consecutive year of budget difficulties - mainly the result of a sharp drop in tax receipts. State governments were expecting financing gaps of around $3 / 4$ percent of GDP in FY 2004, with state employee pension plans also being significantly underfunded. States had largely exhausted the scope for using extra-budgetary funds to meet their balanced budget requirements and had already taken steps to boost fees, freeze salaries and hiring, reduce services, and curb payments to health care providers. Even with the federal aid recently legislated by Congress, more painful cuts in services and tax increases would be required.

23. Officials viewed the weak global environment as a key risk to the domestic outlook. They noted that partner country growth projections had been marked down much more significantly than for the United States and that net exports would likely act as a drag on U.S. demand. Moreover, the dollar's depreciation had been relatively modest in real effective terms, and the U.S. current account deficit would likely remain high in the near term.

24. Federal Reserve officials highlighted that deflation was a small but important risk. ${ }^{6}$ Core inflation indices measured on an annualized 3-month basis had fallen to around 1 percent in recent months, already close to zero, after subtracting measurement biases of around $1 / 2$ percentage point (Figure 12 ). The recent decline - which partly reflected shocks to the relative price of durables and imports - was larger than could be explained by the Fed's statistical models - and with an output gap presently in the range of 2 percent or higherinflation could fall further. However, outright deflation seemed unlikely in view of the monetary and fiscal stimulus in the pipeline, the fact that inflation expectations seemed well anchored, and the support to prices that would come from the dollar's weakness and recent increases in commodity prices and employment costs.

\section{B. Monetary and Exchange Rate Policies}

\section{Recent policy statements by monetary policymakers have signaled increased} concern regarding the outlook. The Federal Open Market Committee (FOMC) took the unusual step in its May 2003 statement of suggesting that while the risks to growth were balanced in the near term, "the probability of an unwelcome substantial fall in inflation, though minor, exceeds that of a pickup." The statement was perceived by markets as reflecting a heightened concern regarding deflation and suggesting that further easing was in store. As a result, longer-dated yields fell and markets started pricing in at least a further quarter point cut in the federal funds rate target. Indeed, at its late June meeting, the FOMC re-affirmed its concern regarding a possible further decline in inflation and lowered its target for the federal funds rate 25 basis points.

\footnotetext{
${ }^{5}$ See the forthcoming Selected Issues paper for a more detailed discussion.

6 The IMF's April 2003 Task Force report—Deflation: Determinants, Risks, and Policy Options-concluded that the risk of U.S. deflation was low, especially in view of the responsiveness of U.S. policymaking.
} 
Figure 12. United States: Inflation Trends

\section{Inflation}

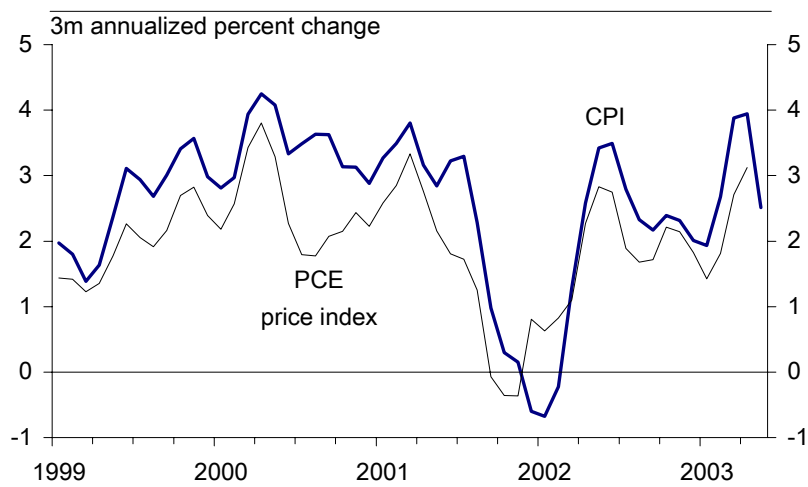

Consumer Prices

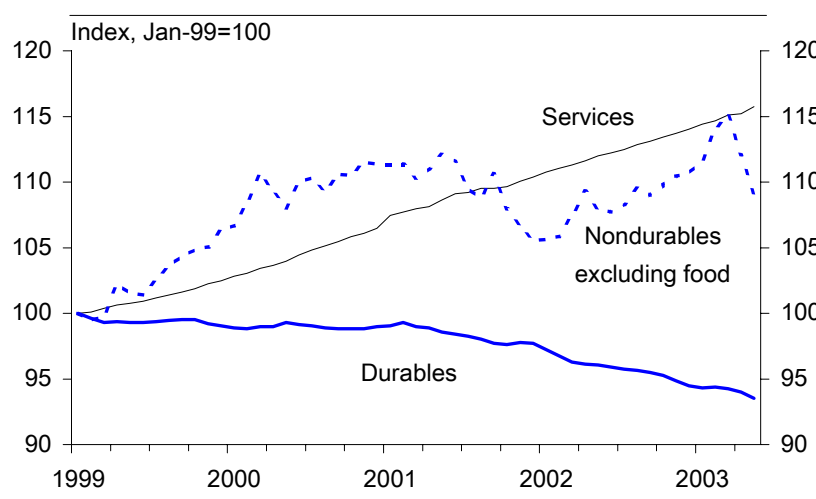

CPI Inflation Expectations from Survey of

Professional Forecasters

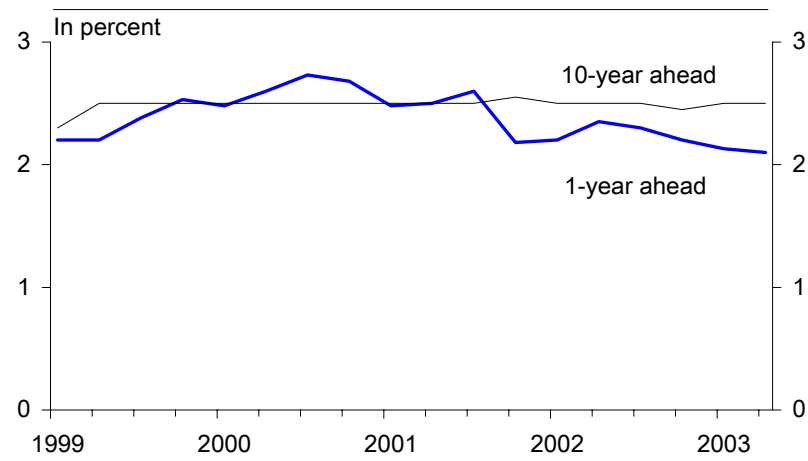

Average Hourly Earnings

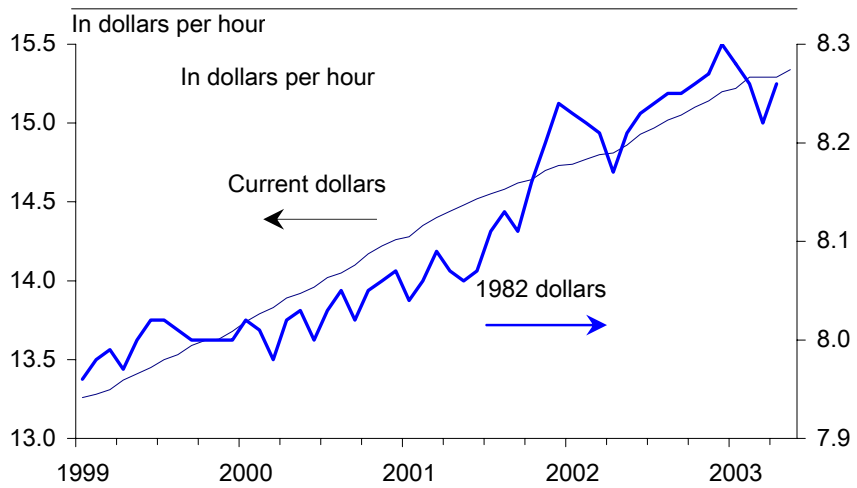

Core Inflation
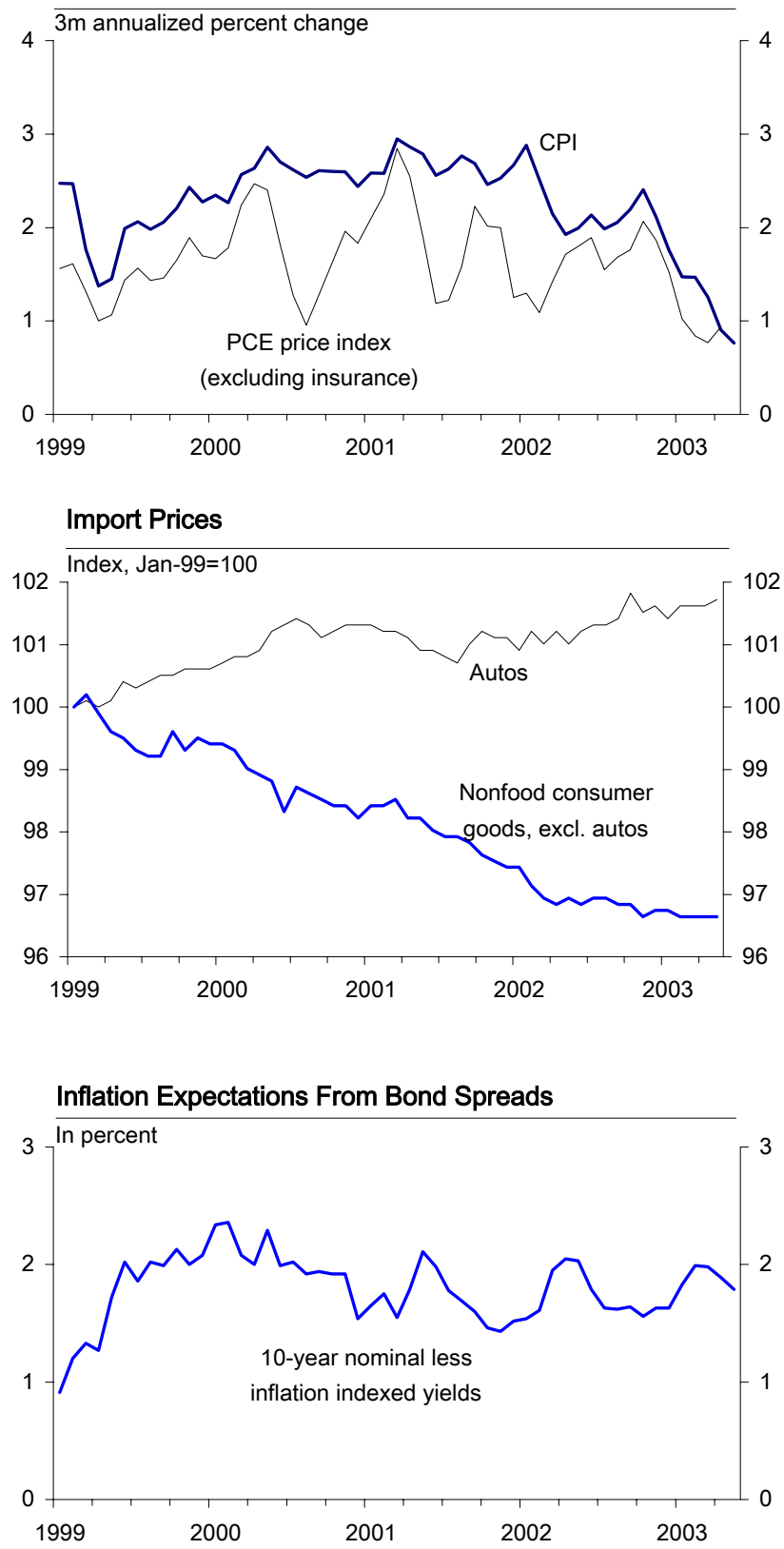

\section{Employment Cost Index}

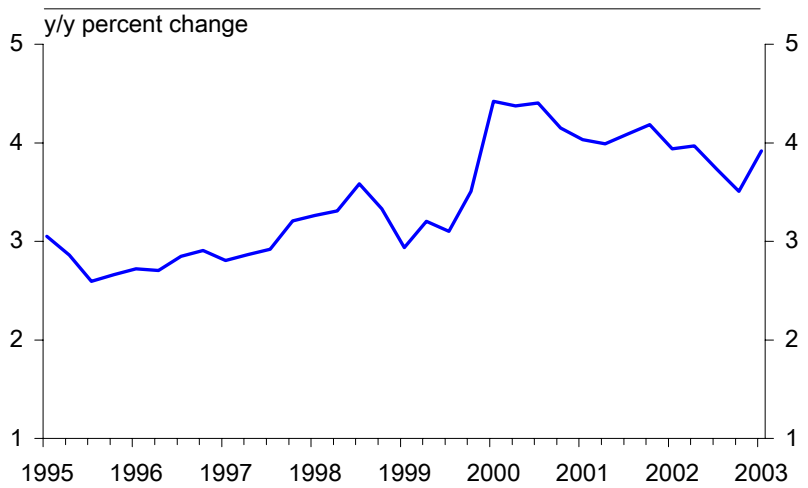


26. The Federal Reserve officials explained that the FOMC's recent statements reflected a view that a deflationary spiral was a low-probability, but high-cost, event. Although relatively benign periods of price declines could occur in the face of favorable productivity or other supply shocks, policy makers were very mindful of the corrosive effects that sustained deflation could have on balance sheets and the effectiveness of conventional monetary policy instruments. With inflation already at a very low level and the output gap likely to remain wide for some time, the economy would be exposed to significant cumulative risk of a large demand shock pushing inflation into negative territory.

27. In discussing the possible merits of further easing, the mission asked whether the sluggish recovery suggested that the interest rate channel for monetary policy had weakened. Officials agreed that activity had been disappointing, especially given the significant monetary and fiscal stimulus that had been injected, but they did not view this as evidence that conventional monetary policy instruments had lost traction. Indeed, the strength of housing investment and durable goods purchases confirmed that the usual transmission mechanism remained effective. However, overall financial conditions had not been as supportive of business investment and external demand, especially given the dollar's earlier strength, heightened risk aversion, and the level of stock prices (Figure 13).

28. Federal Reserve officials expressed confidence that policy instruments would still be available even if short-term interest rates approached zero. If necessary, the Fed would inject liquidity, to expand the size of its balance sheet, and would also operate at different points on the yield curve. The expectations channel also represented a potent instrument, as illustrated by the drop in long-term bond yields following the May FOMC meeting.

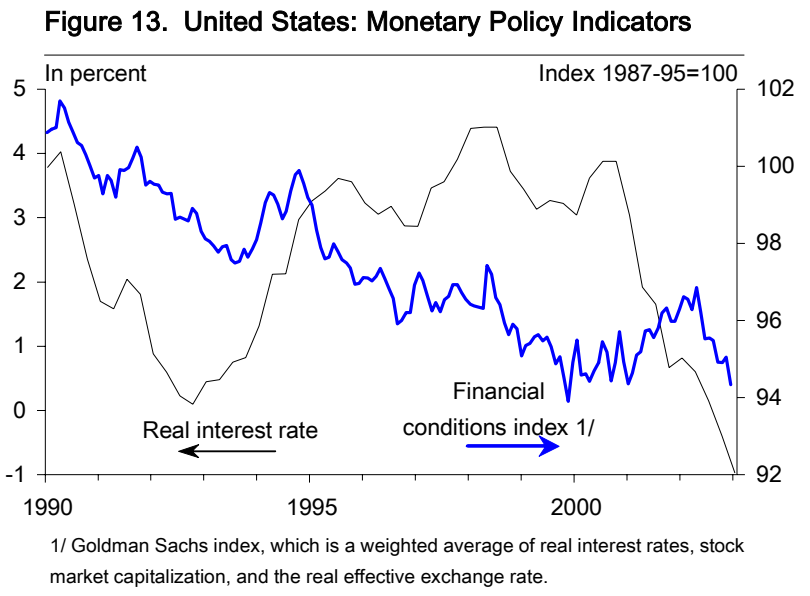

\section{Nonetheless, Federal Reserve officials stressed that there were good reasons to} avoid having to test these unconventional instruments. Most importantly, there was no U.S. experience regarding the quantitative impact of monetary policy close to the zero interest rate bound. Moreover, even moving close to the zero bound could have potentially important adverse microeconomic effects. In a low interest rate environment, money market spreads would become compressed and make it difficult for intermediaries to cover their costs.

30. Staff and Federal Reserve officials agreed that these factors argued for pre-emptive action to avoid deflation. The Japanese experience, in particular, illustrated the importance of demonstrating at an early stage a commitment to avoiding deflation. To this end, U.S. policymakers had actively sought to re-assure markets that the FOMC recognized the potential risks and was prepared to act. 
31. The authorities saw little advantage to stating a quantified medium-term inflation objective, since the FOMC's inflation objectives were well understood. The FOMC's May statement had set a lower bound to its definition of reasonable price stability by signaling a preference to avoid seeing inflation fall further from its present level of around 1 percent. Moreover, surveys and spreads on inflation-indexed bonds showed that expectations were already well anchored. A more specific statement of the Fed's objectives would risk eroding credibility, since the Fed did not have the instruments to hit a particular numerical inflation target exactly and - at times - might wish to give priority to stabilizing economic activity. They acknowledged, however, that opinions varied among the FOMC's members on this issue, and if deflation pressures intensified, interest in this approach might increase. Moreover, the recent experience may have persuaded FOMC members to consider a somewhat higher rate of inflation as consistent with the definition of price stability.

32. The team noted the recent weakening of the U.S. dollar and expressed concern that the large U.S. current account deficit created risks of disorderly adjustments. Especially given the weakening of public saving, the U.S. current account deficit seemed likely to remain at a high level and take the U.S. net foreign liability position to over 40 percent of GDP by 2008. Against this background, the dollar still seemed over-valued relative to medium-term fundamentals, and a correction - especially if it were triggered by weaker confidence in U.S. productivity rather than stronger growth abroad - could adversely affect both the United States and partner countries. Key channels would be: a significant increase in borrowing costs for U.S. firms; an erosion of competitiveness for foreign producers; and substantial capital losses on foreign holdings of U.S. assets. ${ }^{7}$

\section{U.S. Treasury officials stressed that recent exchange rate movements had been} orderly and that there had been no change in the authorities' policy approaches. The fact that the dollar's depreciation had been accompanied by rallies in bond and stock markets demonstrated continued confidence in the U.S. economy. Moreover, the dollar's buoyancy since the mid-1990s mainly reflected a market response to the strength of U.S. macroeconomic performance. Thus, in their view, as long as the exchange rate did not reflect policy missteps, the current account deficit was not a cause for concern. The authorities also dismissed the possible need for foreign exchange market intervention, since even coordinated intervention tended to have little sustained effect.

\section{Federal Reserve officials also saw little risk of disorderly adjustment, while} acknowledging that the present current account deficit would be difficult to sustain. Deficits of this magnitude would imply rapid increases in U.S. net foreign liabilities, requiring

\footnotetext{
7 See Appendix III, as well as the 2002 Staff Report and Selected Issues paper, for debt sustainability analyses. U.S. assets abroad reached around 60 percent of GDP in 2001 and were mostly denominated in foreign currency, while foreign assets in the United States totaled around 80 percent of GDP and were largely denominated in U.S. dollars, implying that a depreciation of the dollar would impose significant capital losses on foreigners and help to erase the net U.S. liability.
} 
a willingness by foreigners to continue to increase their share of U.S. assets. As investment income outflows increased, an ever-larger correction in the trade balance and exchange rates would eventually be necessary to service external debt and stabilize the net liability position.

\section{Fiscal Policy}

\section{Fiscal policy discussions took place against the backdrop of the Congressional} debate over the Administration's February 2003 Budget and tax cut proposals. Following two years of unprecedented fiscal stimulus, the Administration's FY 2004 Budget called for further increases in the fiscal deficits reflecting:

- Tax cuts-Proposals included the elimination of the double taxation of dividends, the acceleration of earlier-scheduled reductions in marginal tax rates, and an expansion of tax preferences for savings.

- $\quad$ Spending increases-Proposed increases in outlays for Medicaid, income security, and a prescription drug benefit under the Medicare program would be only partly offset by assumed cost savings from improvements in the administration of Social Security (Figure 14).

Discretionary spendingspending requiring annual Congressional appropriationswould grow $1 \frac{1}{4}$ percent faster than in the current services baseline over FY 2004-FY 2008, driven by increases for defense and homeland security, while other discretionary spending would decline in real terms.

\section{Congress has moved swiftly to} implement many of these measures (Box 3). In April, an $\$ 80$ billion supplemental spending bill was approved, Figure 14. United States: Federal Outlays, FY 2004-2008

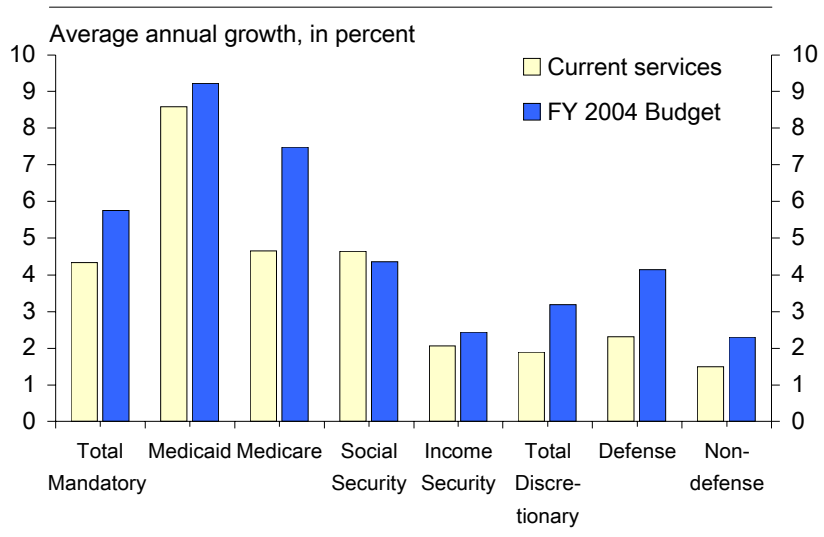

\begin{tabular}{|lcccc|}
\hline \multicolumn{4}{|c|}{$\begin{array}{c}\text { Budget Projections } \\
\text { (In percent of GDP) }\end{array}$} \\
\hline & \multicolumn{5}{c}{ Fiscal Years } \\
\cline { 2 - 5 } & 2002 & 2003 & 2004 & 2008 \\
\hline FY 2004 budget & & & & \\
Unified balance & -1.5 & -3.1 & -3.0 & -1.2 \\
$\quad$ Excl. Social Security & -3.1 & -4.6 & -4.6 & -3.0 \\
Debt held by the public & 33.0 & 34.5 & 35.7 & 34.1 \\
Staff estimates & & & & \\
Unified balance & -1.5 & -4.0 & -4.0 & -1.8 \\
$\quad$ Excl. Social Security & -3.1 & -5.5 & -5.5 & -3.6 \\
Debt held by the public & 33.0 & 35.5 & 37.7 & 37.2 \\
\hline Sources: FY 2004 Budget of the U.S. Government; and IMF staff estimates. \\
\hline
\end{tabular}
aimed mostly at covering the cost of the Iraq war. In May, the bulk of the Administration's tax proposals were legislated, as well as extended unemployment insurance benefits and aid for the states. Although the ten-year cost of the package was placed at only $\$ 350$ billion, this reflected the inclusion of "sunset" 


\section{Box 3. Recent U.S. Tax Initiatives}

Significant tax cuts were legislated in April 2001. The measures included: an immediate 1 percentage point reduction in personal income tax rates for most brackets, and further 1 percentage point cuts in 2004 and 2006; a gradual elimination of the estate tax by 2010; phased increases in the child tax credit; and tax relief for married couples phased in over 2005-2009. The ten-year cost of the measures was held to $\$ 1.35$ trillion by phasing them in gradually and allowing them to expire after 2010.

Further tax cuts were proposed in February 2003 as a part of the Administration's FY 2004 Budget. The measures were estimated to cost a cumulative \$1.3 trillion over FY 2004-2013, and included:

- An economic growth package that would bring forward to 2003 the previously-scheduled reductions in marginal tax rates, increases in the child tax credit, and marriage penalty relief; eliminate the double taxation of dividends; and provide temporary tax incentives for businesses investment. Cost: $\$ 726$ billion over FY 2004-FY 2013.

- Other tax incentives, including measures to encourage saving, charitable giving, and health care; unemployment insurance reform; and tax simplification. Cost: \$114 billion.

- Permanent extension of expiring tax provisions, including the 2001 cuts. Cost: $\$ 588$ billion.

The Jobs and Growth Tax Relief Reconciliation Act of May 2003 contained most of the Administration's growth package. However, dividends were not fully excluded from personal income tax, and the measures were made subject to sunsets in order to contain the total cost to $\$ 350$ billion through FY 2013. The package included:

- Dividends and capital gains - The tax rate on capital gains was lowered to 15 percent and was applied to dividends. A 10 percent rate for lowincome households was to be reduced in phases to zero percent for low-income brackets by 2008. These measures would expire after 2008.

- Personal income tax rates-The tax rate reductions scheduled for 2004 and 2006 were brought forward to 2003 , lowering brackets from $27,30,35$, and 38.6 percent to $25,28,33$, and 35 percent, respectively. However, the rates would revert to pre-2001 levels after 2010 . The expansion of the 10 percent income bracket scheduled for 2008 was also brought forward to 2003 but would expire after 2007.

- Marriage penalty - The standard tax deduction for married taxpayers filing joint returns was increased to 200 percent of that for single taxpayers beginning in 2003 but would expire after 2004.

- Child tax credit -The child tax credit was increased from $\$ 600$ to $\$ 1,000$ in 2003 and 2004 , reverting to $\$ 500$ in 2011.

- Alternative Minimum Tax (AMT) - AMT exemption levels were increased in 2003-2005
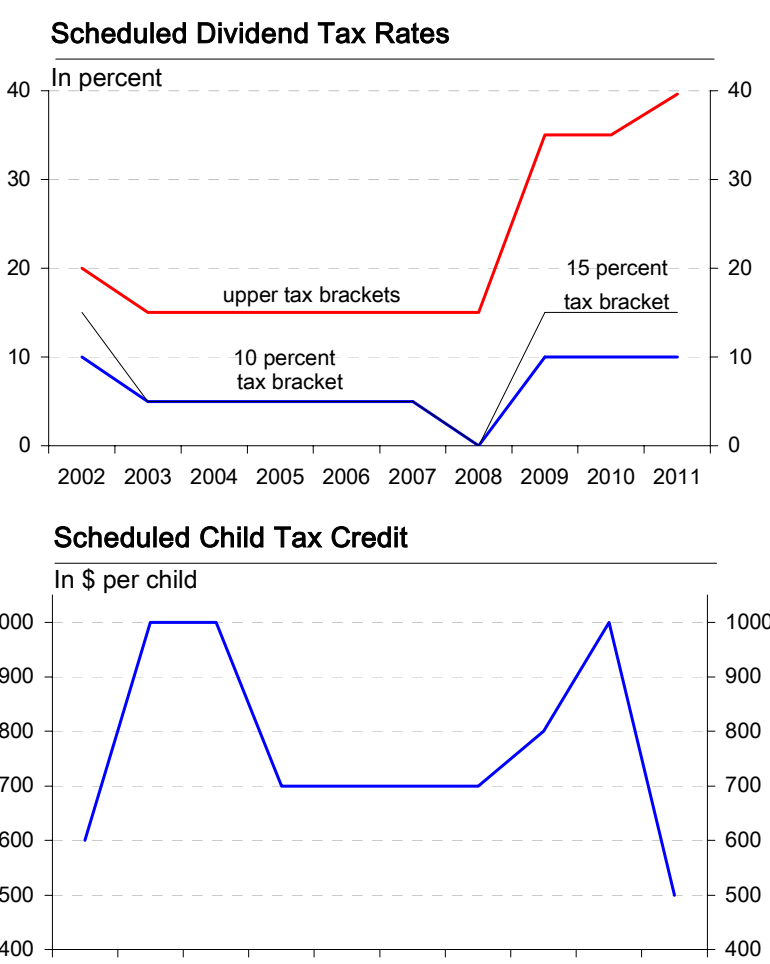

2002200320042005200620072008200920102011 by $\$ 4,000$ for single tax payers and $\$ 8,000$ for married taxpayers filing joint returns, reverting to previous levels thereafter.

- Investment incentives - The annual deduction for small business investment was increased to $\$ 100,000$ with expanded eligibility, and the first-year depreciation for some capital expenses was raised to 50 percent, with both measures expiring after 2004. 
provisions that would cause the tax cuts to begin to expire as early as in 2005 . Congress is also now considering legislation to expand Medicare benefits, at a cost of $\$ 400$ billion over ten years.

37. The mission expressed concern that these measures significantly worsened the fiscal outlook (Table 5). ${ }^{8}$ Staff projects the budget deficit to reach around 4 percent of GDP in both FY 2003 and FY 2004, roughly

$2 \frac{1}{2}$ percentage points above the FY 2004 current-services baseline published in February. The deficit is projected to decline gradually to around $13 / 4$ percent of GDP in FY 2008, around $2 \frac{1 / 4}{4}$ percent of GDP higher than under the baseline, and the debt ratio would be roughly 15 percentage points higher as a result by FY 2012 (Figures 15 and 16). The risks to these projections also appear substantial, since they are predicated on a rebound in revenue buoyancies, which have been depressed as a result of the stock market collapse, and since the policies necessary to hold nondefense outlays roughly constant in real terms have not been defined (Figure 17). ${ }^{9}$ Less optimistic assumptions could add a further $1 \frac{1}{2}$ percent of GDP to the deficit forecast for FY 2008. (Appendix III illustrates the range of uncertainty that attaches to the fiscal projections.)
Figure 15. United States: Unified Balance

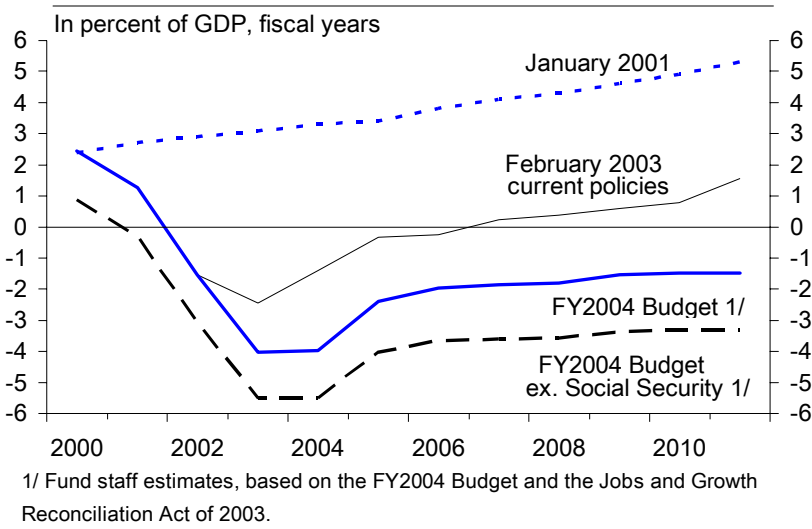

Figure 16. United States: Federal Debt Held by Public

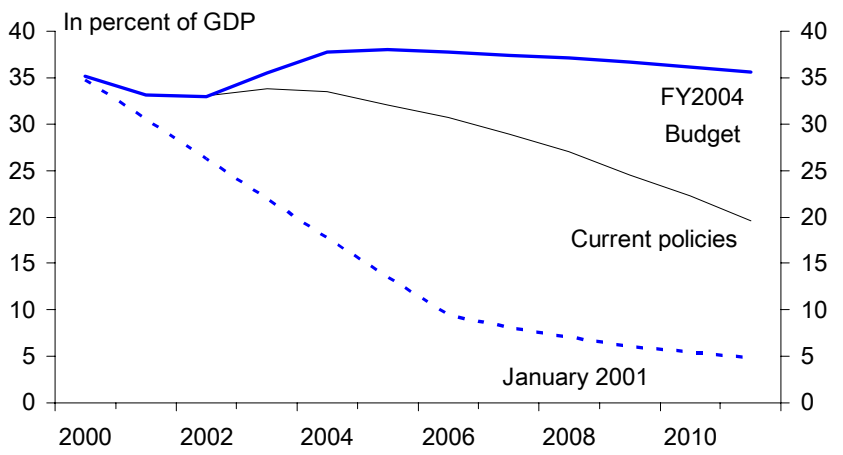

Figure 17. United States: Fiscal Risks

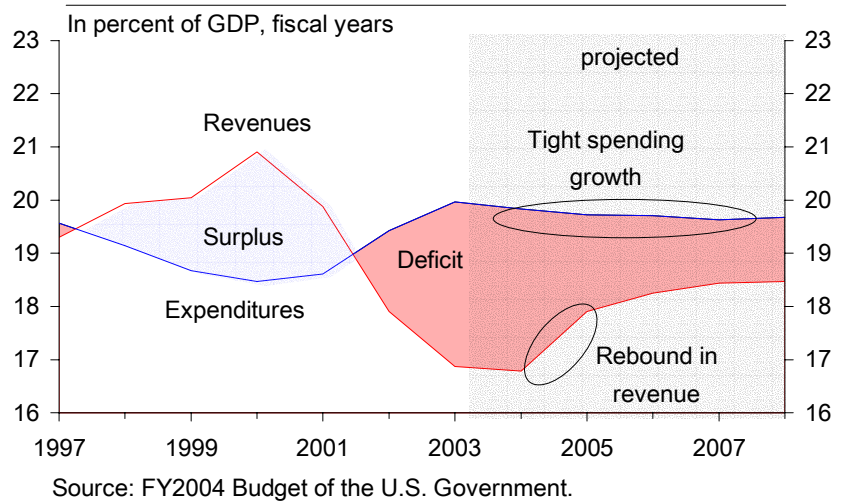

${ }^{8}$ Staff budget projections are based on the Budget projections adjusted to take into account: (i) recent supplemental spending appropriations and the May 2003 tax package; (ii) differences between macroeconomic assumptions;

(iii) the likelihood that additional Alternative Minimum Tax (AMT) relief would be provided, costing $1 / 2$ percent of GDP annually; and (iv) higher growth of discretionary and Medicare spending, in line with Congressional Budget Office (CBO) projections. The 2001 and 2003 tax cuts are assumed to be made permanent, in line with Administration policy statements.

${ }^{9}$ Proposals to further expand the child tax credit to lower income households could add an additional \$10-80 billion to the cost of the May 2003 legislation. 
38. The staff's concerns are heightened by the projected impact of demographic trends on the longer-term fiscal position. Although the expected increase in the old-age dependency ratio is less severe than for many other industrial countries, outlays for Social Security and Medicare are projected to surge, owing to the retirement of the baby-boom generation beginning later this decade and the continued rapid growth of medical costs (Figure 18). The unfunded actuarial liability of these two entitlement programs is estimated at 180 percent of GDP over a 75-year horizon, and since the systems would remain in substantial deficit even beyond that period, longer-term estimates place the unfunded liability at around 400 percent of GDP. ${ }^{10}$

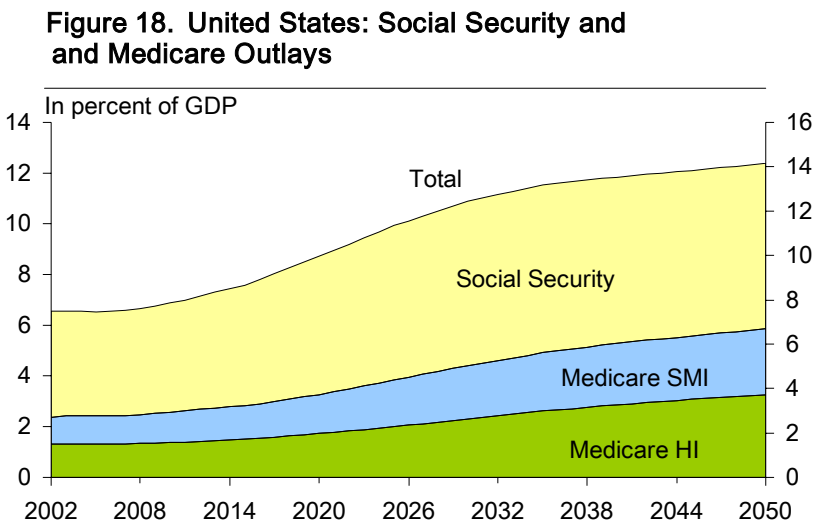

39. U.S. officials considered that the fiscal position remained manageable and stressed that the Administration's initiatives would yield both short-term and long-term benefits. In the short term, the tax cuts and spending increases would provide important insurance for the recovery, especially given the weakening of activity since late 2002 and the limited room for further interest rate cuts. Since much of the package involved bringing forward tax cuts that were already scheduled for 2004 and 2006, the long-run impact on the fiscal position was relatively modest, and the deficit and federal debt as a share of GDP would remain relatively low into the medium term. Moreover, the tax cuts would lower the cost of capital, move the tax system closer to a consumption basis, and yield important supply-side benefits, which would also help offset the fiscal costs.

40. The U.S. officials expressed confidence in the budget projections. They acknowledged that revenue receipts still remained depressed, but the Administration's revenue forecast was in line with that of the $\mathrm{CBO}$, which also assumed a rebound in the revenue ratio once capital gains realizations normalized. Although the Budget had not specified explicit policies to achieve the projected compression of discretionary spending, there was little purpose to such an exercise beyond the next fiscal year, given that these expenditures were subject to annual appropriations by Congress.

\footnotetext{
10 The Social Security system is funded by a 12.4 percent payroll tax and has accrued financial assetsgovernment securities - totaling around 14 percent of GDP. The Medicare system — which includes Hospital Insurance (HI) and Supplemental Medical Insurance (SMI) - is only partly funded by a dedicated payroll tax of 2.9 percent and premium payments by the elderly, and it has accrued assets of only around 2 percent of GDP. See the 2002 Selected Issues paper for details and long-term projections.
} 
41. The staff representatives questioned whether the tax cuts would have significant demand-and supply-side benefits. Since the benefits seemed to accrue largely to higherincome households, and the sunsets meant that the cuts would be viewed at least partially as temporary, the effect on demand could be muted. The longer-term, efficiency gains might also be modest since Congress had backed away from the measures with the greatest structural benefits - including the elimination of the double taxation of dividends and the reform of tax deferred savings plans - while leaving the permanence of the remaining measures uncertain. In addition, the higher deficits now projected would eventually tend to crowd out investment, thus offsetting any efficiency gains that might result (Box 4). The Treasury officials responded that, in their view, budget deficits typically had only a small effect on interest rates, and crowding out seemed unlikely given how low bond yields were presently and given the modest deficits that were projected in the period ahead.

\section{The mission expressed concern regarding the apparent weakening of fiscal}

discipline and fiscal transparency in recent years. The staff's Fiscal ROSC recognized that the U.S. fiscal system set a high standard in many respects, but noted the absence of an effective medium- and long-term fiscal framework (Box 5). Budget Enforcement Act (BEA) rules had been circumvented in recent years and had been allowed to expire altogether in 2002; phasing and sunsets had been used to understate the longer-run cost of the 2001 and 2003 tax cuts; and the Administration had opted to forgo ten-year budget projections.

43. The U.S. officials agreed with the need for greater spending discipline. In their view, the principal cause for the widening of the fiscal deficit in recent years was the rapid growth of discretionary spending, which implied that tighter control of expenditures was essential to narrow the deficit. The Administration supported the re-authorization and strengthening of the BEA's discretionary spending caps and pay-as-you-go (PAYGO) requirements, as well as a line-item veto and two year budgeting, but there did not yet seem to be sufficient political backing. In any event, the officials noted that these types of budget rules had not proven effective in the face of budget surpluses, and they suggested that the recent tax cuts_-by reducing available resources - could also help discipline spending.

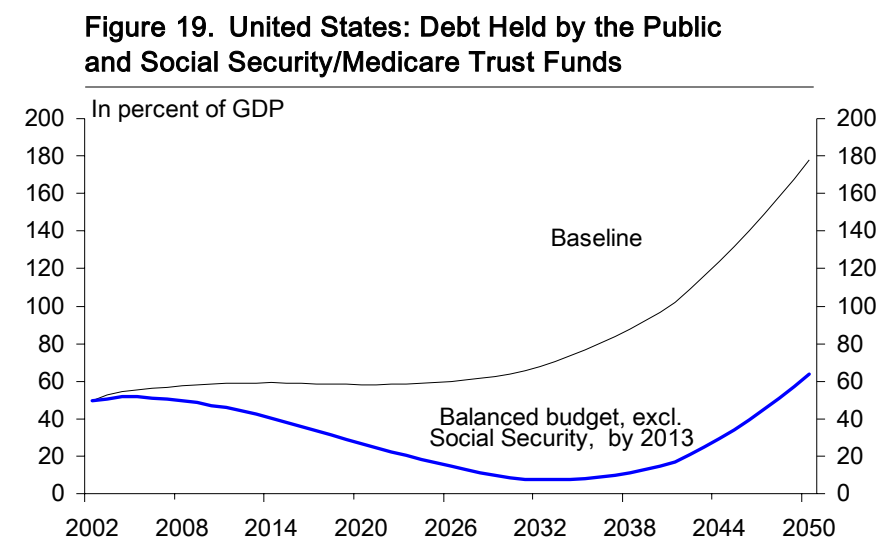

44. The mission repeated the staff's long-standing call for a credible, medium-term commitment to balancing the budget, excluding Social Security, and for measures to place the Social Security and Medicare systems on a sound financial footing (Figure 19). Restoring a balanced budget, excluding Social Security—which had been the Administration's 


\section{Box 4. The Macroeconomic and Multilateral Effects of Budget Deficits}

The U.S. federal budget outlook has deteriorated considerably in recent years. In 2000, Congressional Budget Office (CBO) projections were for surpluses to remain in the range of 3 percent of GDP for the next 10 years and for the federal debt to be nearly eliminated by 2010 . However, with the introduction of tax cuts in 2001, considerably weaker-than-expected revenue performance, and the tax cuts enacted in May this year, substantial federal deficits are likely to persist for the next decade. CBO estimates that the federal deficit would average around $13 / 4$ percent of GDP and that publicly held debt would remain in the range of 35 percent of GDP over 2004-2013, before beginning to rise sharply in the face of adverse demographic trends.

The sharp turnaround in the budget outlook has revived the long-standing debate about the impact of fiscal deficits on interest rates and economic growth. Some economists have argued that any impact of budget deficits on interest rates would be small and outweighed by the favorable supply-side effects of Administration policies. Others, however, have stressed the risk that large deficits would boost interest rates, lower investment, and reduce the economy's long-run potential.

Recent empirical evidence lends support to the view that budget deficits raise interest rates. Although a number of past studies suggest that deficits would have only a negligible impact on interest rates, Gale and Orszag (2002) argue that most of these studies have not adequately taken into account that financial markets are forward-looking and that interest rates respond to expectations of future government deficits and debt. They illustrate that there is a positive correlation between the five-year cumulative deficits projected by the CBO and spreads on longer and short-term bonds. Moreover, Gale and Orszag survey a range of standard macroeconomic forecasting models and show that such models typically would predict a 50 basis point increase in bond yields for a 1 percentage point of GDP (tax-cut induced) increase in the federal deficit.

Simulations of the 2003 Administration's original tax cut proposal using macroeconomic models also illustrate its long-term costs. Macroeconomic Advisors and Global Insight report simulations showing that the Administration's plan would provide a sizeable short-term boost to activity, raising GDP by up to $1 \frac{1}{2} 2$ percent above baseline by 2004, but output would fall back to its baseline by around 2007-2008. Thereafter, fiscal deficits and higher long-term interest rates would cause a decrease in output. Similarly, a recent CBO (2003) report shows that, unless the tax cuts are reversed at some point in the future, they would reduce output over the long run (by around $1 / 2-1 \frac{1}{2}$ percent), owing to slower capital accumulation.

The international implications of higher U.S. fiscal deficits may also be important. Given the increased integration of financial markets, the U.S. fiscal policy could have a significant influence on the U.S. current account deficits and on real interest rates in other countries. Simulations of the Oxford Economic Forecasting model show that a 1 percent of GDP increase in the U.S. fiscal deficit results in a $1 / 2$ percent of GDP increase in the current account deficit. Moreover, the large share of U.S. public debt in global markets suggests that higher levels of U.S. public debt might spill over to the rest of the world and cause higher global interest rates. Staff estimates show that the Administration's tax cuts could lead to a $1 / 2-1$ percentage point increase in world real interest rates over the next decade.

References: Further details can be found in the forthcoming Selected Issues paper; W. Gale and P. Orszag, 2002, "The Economic Effects Of Long-Term Fiscal Discipline," Urban-Brookings Tax Policy Center Discussion Paper; and CBO, 2003, An Analysis of the President's Budgetary Proposals for Fiscal Year 2004. 


\section{Box 5. Fiscal Transparency in the United States}

During November 2002-February 2003, a staff team conducted a review of fiscal transparency in the United States in relation to the IMF's Code of Good Practices on Fiscal Transparency. ${ }^{1}$ The

principal conclusions of that review are as follows:

- The United States is fully compliant with most elements of the Fund's Code of Good Practices on Fiscal Transparency and sets best practice standards in many areas. The U.S. constitution provides a strong and well-tested framework that clearly defines the roles of the executive and legislative branches in fiscal management. The Congress plays a central role in shaping the budget, which ensures a highly open process. State and local governments also have clearly defined fiscal responsibilities, operating independently from the federal government, and they are subject to market discipline. Budget documentation is easily accessible to the public, timely, comprehensive, and reliable, and it excels in its scope and quality of analysis.

- Nevertheless, there remains a lack of clarity about the longer-term direction of fiscal policy. This partly reflects the sheer size of the federal government and the complexity of the Congressional budget process. Major efforts have been made over the past three decades to put in place a legal framework to strengthen this aspect of the budget process. However, with the expiration of the Budget Enforcement Act (BEA), the failure of Congress to pass a budget resolution for FY 2003, and the recent uncertainty regarding the permanence of tax cuts and the costs of the war in Iraq, budget decisions do not seem presently guided by clear medium- and long-term fiscal policy objectives.

- Budget responsibility legislation to replace the BEA could help provide a basis for a more systematic incorporation of longer-term considerations into the budget process. Building on existing budget requirements and practices, such a budget framework could require: the specification and justification of medium-term fiscal targets as part of the President's budget; a budget report on long-term fiscal policy; discretionary spending caps and pay-as-you-go (PAYGO) requirements for mandatory spending and revenue; and clearer procedures for specifying and disclosing key budget assumptions (e.g., with respect to expiring legislation).

- Fiscal transparency could be strengthened in a number of additional ways. These include: reporting an internationally comparable measure of the budget balance to supplement the unified budget presentation; providing an overview of state and local government finances as part of the federal budget presentation; an annual assessment of the costs and risks associated with the quasifiscal activities; including a comprehensive statement on fiscal risks in budget documents; reconsidering the legal basis for tax expenditure reporting; ensuring that audit reports of agencies by the General Accounting Office (GAO) are followed up, possibly by a standing public accounts committee that reports to Congress; an increased emphasis on program performance; and greater attention to the full cost of providing government services.

${ }^{1}$ See United States: Report on Observance of Standards and Codes (ROSC) Fiscal Transparency Module, June 2003. 
stated goal two years ago - over the next five to ten years would significantly lower total federal debt (including obligations to the Social Security and Medicare trust funds) ahead of the coming demographic shift. Such an adjustment would provide the time that would likely be needed to design and phase in the measures to address the longer-term insolvency of the entitlement programs. Although spending cuts could represent an important component of the consolidation strategy, it was difficult to see how significant savings could be achieved, given the absence of well-defined supporting policies and pressures to boost outlays on defense and other Administration priorities. These considerations and the sizable adjustment that would be needed — over 3 percent of GDP — suggested that revenue enhancements also would be needed, preferably by broadening the tax base. ${ }^{11}$

\section{The authorities were not convinced of the need for a more stringent medium-term}

fiscal objective. They noted that the Budget had already indicated the preference for a balanced budget, including Social Security, and the Budget's projections were consistent with the deficit approaching zero in five to ten years if the favorable supply-side effects of the tax cuts were factored in. In their view, the size of the unfunded liabilities of the retirement and health care were far too large to solve by simply paying down debt, and the problem needed to be addressed directly by reforming these programs over time. In the meantime, they observed that budget deficits in the 2-3 percent of GDP range were still consistent with a stable debt ratio, and the Administration was committed to making the May 2003 tax cuts permanent and to introducing further reductions in tax rates.

\section{The mission stressed that early action was needed to reform the Social Security}

system. A range of options could be considered, including increases in contribution rates, hikes in retirement ages, amendments to indexation formulas, and other programmatic changes. However, measures typically had to be phased in slowly-in order to allow participants to adjust their saving behavior - and delays would only make the necessary adjustments more painful. ${ }^{12}$ U.S. officials acknowledged that little progress had been made toward building a consensus for reform since the report of the President's reform commission had reported in late 2001, but the Administration still strongly favored approaches that provided a role for personal retirement accounts, avoided hikes in contribution rates, and did not disadvantage current and near retirees. They expected that the 2004 elections might provide a useful forum for debating these politically difficult issues.

\footnotetext{
${ }^{11}$ OECD estimates put corporate and personal income tax expenditures at almost 8 percent of GDP and also suggest significant gains from further increasing taxes on energy consumption.

${ }^{12}$ Staff calculations suggest that an immediate 3.9 percentage point increase in contribution rates would cover the unfunded liability of the trust funds, but a 4.9 percentage point increase would be required if the measures were delayed by 10 years.
} 
47. The authorities recognized the need to reform Medicare and Medicaid and placed a priority on expanding the role of the private sector in administering benefits in order to contain costs. For this reason, they had proposed that prescription drug benefits be provided by private plans. The Administration had also called for moving from a costsharing to a block-grant system for Medicaid payments to the states. The mission agreed that the already large share of U.S. GDP devoted to health care and the long-term fiscal constraint argued strongly for efficiency-enhancing reforms (Figure 20). However, the experience with private sector plans in recent years did not suggest that moving seniors into private plans would yield significant savings.

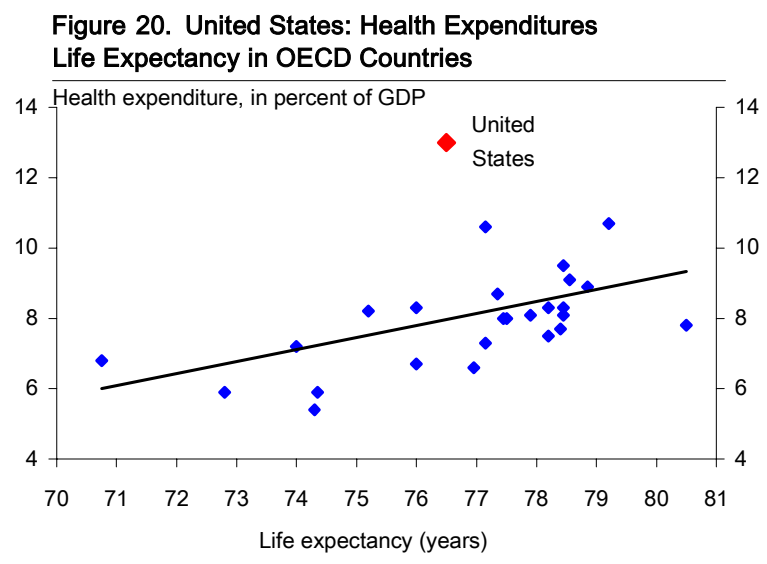

48. Discussions with officials suggested that structural reforms would be needed to resolve the fiscal crisis among the states. Officials stressed that federal policies - including recent tax cuts and reforms to transfer programs - had not significantly disadvantaged the states. The underlying problem was that the states' balanced budget rules had led them to respond to the boom in revenues during the late 1990s by cutting taxes and boosting outlays on social programs. As a consequence, they had been unprepared for the sharp drop in income tax receipts that followed the collapse of the equity price bubble. The mission cautioned, however, that the proposal to shift the funding of state Medicaid programs from a cost-sharing to a block-grant basis could leave the states even more ill-prepared to cope with demographic pressures and suggested that it would be important to coordinate Medicare and Medicaid reform proposals with the states.

\section{Financial Sector Issues}

49. U.S. officials observed that the banking system had remained resilient in the face of the economic slowdown (Table 6). In their view, although a weaker macroeconomic environment or other shocks could adversely affect earnings, the safety and soundness of the system were not at risk. They were mindful of the potential for an eventual return of interest rates to more neutral levels to have adverse balance sheet effects, especially in the case of smaller and mid-sized banks that were less active in hedging exposures. However, bank risk management was sound; the recent growth of core, low interest rate deposits provided a natural hedge; and rate increases would likely only occur in the context of an improved economic setting. The increased use of credit derivatives, syndications, and loan sales had also helped contain credit risks. Officials discounted the possibility of significant deterioration in mortgage portfolios, but acknowledged that the recent growth of home equity lines of credit, as well as the commercial real estate sector, could pose risks. 


\section{U.S. officials expressed confidence that the two large government sponsored} enterprises (GSEs) did not currently pose significant systemic risks. In addition to their more traditional role in securitizing mortgages for purchase by other investors, since the mid1990s Fannie Mae and Freddie Mac have issued significant amounts of debt to fund purchases of mortgage-backed securities, raising concern that the enterprises could exercise undue market power or pose systemic risks. ${ }^{13}$ Officials emphasized, however, that the GSEs were subject to stress tests, and most markets for interest rate derivatives were deep and liquid enough to meet their hedging needs, at least for the present time. They acknowledged that the enterprises' rapid growth at least partly reflected the low cost of borrowing that their special status provided, as well as the perception that they were implicitly backed by the government or were "too big to fail." However, it was not clear that simply limiting their size would reduce systemic risks.

\section{Officials suggested that the Basel II capital accord would yield both opportunities} and challenges. The internal ratings based (IRB) approach was expected to improve risk management and to make capital requirements more risk sensitive, but implementation would be resource-intensive for both banks and supervisors. Since care would be needed to avoid an over-reliance on statistical models in managing risk, Basel II also incorporates enhanced supervisory review and increased disclosure. In order to avoid undue cost and complexity, the United States had opted for a somewhat limited application of Basel II; the new system would be required only of large, internationally active banks, and only the advanced IRB approach would be used. At least initially, this would mean that the new system would be required of around ten banks, although a similar number of other large banks would likely find it advantageous to adopt the new system voluntarily. Nonetheless, questions also had been raised - including in Congress - about whether the system's calibration would disadvantage some institutions.

\section{Progress has been made in strengthening corporate governance and auditor}

oversight. The officials suggested that important factors explaining the corporate malfeasance of recent years seemed to have been weak corporate governance structures, compounded by questionable accounting practices and executive compensation schemes that provided undue incentives to boost short-term share prices, even at the expense of longer-term value. The Sarbanes-Oxley Act of 2002 had responded to these and other concerns by calling for measures, among other things, to increase penalties for fraud and by establishing the Public Company Accounting Oversight Board (PCAOB) to regulate the audit profession. The selfregulatory organizations (e.g., NYSE and NASD) had also introduced new rules to strengthen corporate governance and transparency, including by stiffening the rules governing the independence of company directors, equity-based compensation schemes, and the role and responsibility of audit committees.

\footnotetext{
13 Although GSE debt is explicitly not backed by the government, the GSEs benefit from a $\$ 2.5$ billion credit line with the U.S. Treasury; their debt is exempt from restrictions on banks that limit the amount of securities issued by any single issuer that they may hold; their securities are exempt from SEC registration requirements; and GSE earnings are exempt from state and local income taxes. In addition, these agencies are overseen by a separate federal regulator and are subject to Congressionally mandated capital requirements.
} 
53. Officials agreed, however, that important issues still needed to be addressed. The Chairman of the PCAOB was appointed in April 2003, and the process of registering accounting firms and establishing the rules that would govern their work was still in train. In addition, the Financial Accounting Standards Board has issued new accounting guidance on special purpose entities and guarantees and is pursuing projects related to the accounting for stock compensation and enhancing the disclosure of pension liabilities. Officials emphasized that they were mindful of the international implications of these efforts and that regulators were making efforts to be flexible in the application of new requirements to foreign firms.

54. The mission observed that the underfunding of defined-benefit (DB) corporate pension plans posed important financial, regulatory, and accounting issues. ${ }^{14}$ Severe underfunding had compounded the financial difficulties of a number of firms, particularly within the automotive, steel, and airline industries. The failure of several steel firms with large pension obligations had also put a strain on the financial position of the Pension Benefit Guarantee Corporation (PBGC). The officials indicated that current accounting rules allowed firms to smooth pension plan gains and losses to limit the impact of short-term asset price movements, which could obscure firms' underlying financial position, and there was scope for improving the transparency of pension plan results and required contributions. The PBGC was also exploring options for improving its financial position, but officials noted that its shortfall was modest and likely would be erased once the economy strengthened.

\section{E. Energy, Trade, and Other Policy Issues}

55. The Administration's 2001 National Energy Policy has triggered important debate in Congress. Different versions of an Energy Bill currently before the House and Senate are principally aimed at reducing U.S. energy dependence by boosting supply. Measures include: tax incentives for new technologies, increased funding for research into alternative fuels and technologies, deregulation of wholesale electricity markets, and easing restrictions on oil and gas exploration in ecologically sensitive areas. The mission suggested that demand-side measures, including energy-related taxes, might also assist in supporting environmental and fiscal objectives. ${ }^{15}$ U.S. officials stressed that it was important to strike an appropriate balance between long-term growth and environmental concerns. For this reason, the emphasis was not simply on curbing energy consumption, which would dampen growth, but on marketoriented policies that would balance supply and demand and help meet environmental objectives. They noted, in particular, the Administration's commitment to reduce greenhouse gas emissions by 18 percent by 2012, which they hoped to achieve through voluntary measures, to develop a tradable permit system for emissions, and to provide tax incentives for the production of energy from renewable sources.

\footnotetext{
${ }^{14}$ See the forthcoming Selected Issues paper for details.

15 The forthcoming Selected Issues paper compares U.S. energy taxation with that in other countries, and illustrates that a 10 percentage point increase in energy taxes would lower real GDP by less than 0.1 percent.
} 
56. The mission stressed the importance of U.S. commitment to the multilateral process and its leadership in fostering progress toward a successful completion of the Doha Round. The mission noted, in particular, the need to find common ground with partner countries in areas such as the public health exemption on TRIPs and also called for early action to comply with recent WTO rulings on the safeguard duties on steel imports, rebates of anti-dumping duties and the tax treatment of Foreign Sales Corporations. The USTR representatives responded that the authorities remained committed to trade liberalization and moving the Round forward. In this regard, they noted the Administration's success in gaining Congressional support for Trade Promotion Authority and, in the context of the Doha Round, far-reaching proposals had been made for liberalization in most areas.

57. The mission asked about the prospects for resolving difficult sector-specific issues, especially in light of last year's Farm Bill and the safeguard duties imposed on steel imports and their impact on developing countries. ${ }^{16}$ The USTR representatives agreed that agricultural subsidies represented a potential stumbling block for the WTO negotiations but underlined that the Farm Bill would not be an obstacle to liberalization. The U.S. proposal would cut the global average tariff on agricultural products from 62 percent to 15 percent and reduce global trade distorting support by over $\$ 100$ billion. As for the steel sector, the domestic industry was in the process of restructuring, and discussions were under way within the OECD on how to reduce global excess capacity. Although many of the most sensitive textiles quotas were still in place, the U.S. textiles sector had also made considerable adjustment in advance of their expiration at end-2004. Responding to the mission's concern about the continued use of anti-dumping and countervailing duty remedies, they argued that U.S. practice was transparent and WTO compliant; more worrisome was the increasing resort to such remedies in other countries where the process was nontransparent.

58. The mission asked about the implications of the U.S. emphasis on regional and bilateral free trade arrangements (FTAs) for the multilateral trading system (Box 6). In particular, while such arrangements could bring substantial benefits to the countries involved, it was important to ensure that they were designed in a manner that limited trade diversion and avoided administrative complexity, and that they did not undermine the momentum toward multilateral liberalization, including by diverting scarce negotiating capacity in other countries. The mission also cautioned that the investment provisions of recent FTAs could limit the flexibility of countries in controlling the pace of capital flows in the event of crises.

59. The USTR representatives responded that they viewed bilateral and regional FTAs as an important complement to their multilateral strategy of "competitive liberalization." Negotiating trade arrangements with a smaller number of partners meant that there was scope for deeper liberalization, including in services, investment, and regulatory matters, which helped set a higher standard for subsequent agreements and the multilateral negotiations.

\footnotetext{
16 The 2002 Selected Issues paper contained detailed analysis of the multilateral implications of the U.S. Farm Bill and steel tariffs.
} 


\section{Box 6. U.S. Macroeconomic Developments and Trade Policies-Multilateral Implications ${ }^{1}$}

- Global linkages between the United States and the rest of the world have grown rapidly in recent decades. International trade - the sum of exports and imports - has grown at roughly three times the rate of GDP in the United States since 1960, and gross cross-border financial flows have risen from less than 3 percent to more than 18 percent of GDP since the early 1980s.

- Stronger trade and financial linkages have increased the extent of macroeconomic spillovers. For example, staff estimates show that the comovement of business cycles in the United States and in other G-7 countries has increased in recent decades, and the role of global factors in explaining individual country business cycles has become more pronounced. The United States has also been an important driver of these global factors, with the correlation between U.S. output growth and the median global factor at $0.62 .{ }^{2}$

- The important role played by trade arrangements for cross-border trade, financial flows, and growth is illustrated by the North American Free Trade Agreement (NAFTA). Since the inception of NAFTA in 1994, U.S. exports to its NAFTA partners have climbed nearly 90 percent, and Mexico's exports to the United States and Canada have tripled. FDI flows to Mexico increased from $\$ 12$ billion over 1991-1993 to roughly $\$ 54$ billion in 2000-2002. Recent estimates indicate that NAFTA membership helped boost annual FDI inflows to Mexico by roughly 40 percent, and that NAFTA has contributed significantly to employment and productivity growth in Mexico. ${ }^{3}$

- Staff analysis suggests that free trade arrangements (FTAs) such as NAFTA have important implications for business cycle dynamics. Since the advent of NAFTA, the co-movement of real GDP and other important macroeconomic aggregates of the member countries has increased markedly. Estimates from a dynamic factor model suggest that the proportion of GDP variability in Mexico explained by regional (versus country-specific) shocks has increased from 1 percent in the period 1980-1993 to more than 19 percent during 1994-2002.

- These issues have become increasingly important with the greater emphasis that has been placed by the United States on regional and bilateral FTAs. A Free Trade Area of the Americas is planned for the United States and 33 other countries in the Western Hemisphere by the end of 2005. The United States signed FTAs with Chile and Singapore in 2003 and has also begun FTA negotiations with Morocco, Central America, the Southern African Customs Union, and Australia. Work has begun on a broad-based trade initiative in the Middle East, and preferential market access has been provided through the Andean Trade Preferences Act and the African Growth and Opportunity Act.

- Model simulations illustrate the potential benefits of regional and bilateral FTAs. Stylized representations of the U.S.-Chile, U.S.-Australia, and U.S.-Central America arrangements suggest that export performance improves for partner countries in areas of comparative advantage but that welfare losses can result owing to trade diversion (unambiguously so for non-members). The results suggest that the maximum benefits from participation in FTAs occur if they are used as a stepping stone to lowering trade barriers with other partners. In addition, FTAs are likely to have benefits in areas such as services trade and investment that are not captured by conventional trade models.

\footnotetext{
${ }^{1}$ These issues are discussed in greater detail in the forthcoming Selected Issues paper.

${ }^{2}$ See also, V. Arora and V. Athanasios, 2001, "The Impact of U.S. Economic Growth on the Rest of the World: How Much Does it Matter?" IMF Working Paper WP/01/119.

${ }^{3}$ See Congressional Budget Office, 2003, The Effects of NAFTA on U.S.-Mexican Trade and GDP.
} 
Bilateral arrangements also were viewed as helpful in supporting overseas development. The USTR representatives agreed, however, that bilateral arrangements could create coordination problems, and technical assistance was being provided to assist in negotiations.

60. Despite recent increases, U.S. official development assistance (ODA) remains at only 0.12 percent of $G N P$, the lowest ratio among industrial countries. The staff representatives welcomed the Administration's recent commitment to boost ODA, including for the Millennium Challenge Account (MCA) and the Emergency Plan for AIDS Relief. ${ }^{17}$ The U.S. representatives noted that the MCA, in particular, was geared toward improving the effectiveness of ODA by disbursing funds to countries on the basis of clearly defined criteria that demonstrated their institutional capacity as well as effective management of social and economic policies. Although the number of countries that would meet this test would be limited, concentrating ODA on good performers was likely to improve its overall effectiveness. At the same time, however, the traditional ODA budget would remain available for those countries unable to meet the MCA criteria.

\section{The U.S. officials noted that efforts had intensified in the area of anti-money} laundering (AML) enforcement and combating the financing of terrorism (CFT). Substantial progress has been made to implement the USA PATRIOT Act during the past year, and guidelines were being established to help quantify progress in the AML/CFT area. ${ }^{18}$ A priority was also being placed on collaboration with other countries and international institutions to encourage greater harmonization of AML/CFT regulations. The U.S. officials acknowledged that the United States was still not in full compliance with some of the Financial Action Task Force recommendations, but they were confident that this would be achieved in two years.

\section{Staff Appraisal}

62. Despite repeated shocks in recent years, the U.S. economy has provided valuable support for global growth. The relative strength of the U.S. economy has reflected the exceptional stimulus provided by monetary and fiscal policies, as well as the economy's remarkable resilience and flexibility, which has contributed to continued productivity growth.

\section{However, the recovery has been uneven, and short-term prospects remain}

uncertain. Growth is expected to rise above its potential rate in the latter half of 2003 and into 2004, with the relatively quick resolution of the Iraq war, lower oil prices, and further

\footnotetext{
${ }^{17}$ The MCA — which is expected to receive funding rising from $\$ 1.3$ billion in FY 2004 to $\$ 5$ billion by FY 2006 - would provide grants targeted to a limited set of countries meeting well-defined performance criteria. The Emergency Plan for AIDS Relief would commit \$2 billion in FY 2004 and \$15 billion over the next five years for large-scale AIDS/HIV prevention and treatment efforts in developing countries.

18 In June 2002, the Administration released its second National Money Laundering Strategy, which provided a detailed account of the progress made and described a comprehensive framework to combat money laundering.
} 
support from monetary and fiscal policies. However, it remains to be seen whether the adjustments associated with the unwinding of the equity price bubble have fully run their course, and downside risks remain a concern given the continued weakness of industrial activity, employment, and the proximity of the zero bound on interest rates.

\section{Recent tax cuts have reduced the room for further fiscal policy maneuver and} heightened concern regarding long-term sustainability. While fiscal policies have helped support the recovery so far, tax cuts have left the fiscal position even less prepared to cope with the retirement of the baby-boom generation later this decade. Sustained fiscal deficits would eventually crowd out investment and erode U.S. productivity growth. They would also tend to boost the already large U.S. current account deficit, imposing a further drain on global saving and increasing the risk of disorderly exchange market conditions.

65. Against this background, the key task is to manage short-term risks to the outlook, while establishing a credible approach to dealing with the longer-term fiscal problem. Responding effectively to this challenge will help promote growth as well as domestic and external sustainability, in line with the G-7 finance ministers' commitment to cooperate to promote global economic growth.

66. While monetary policy has responded aggressively to the economic slowdown, further easing may still be required if the recovery does not regain momentum. The FOMC has appropriately signaled its readiness to act further, if necessary, and its willingness to use a broader range of policy instruments should deflationary pressures intensify. A quantified statement of the Federal Reserve's inflation objective could further anchor inflation expectations, which might be especially helpful now that interest rates have moved close to zero and deflation is a concern.

67. The dollar's recent weakness has added to uncertainty. The authorities have correctly emphasized that exchange rates have responded to market forces and that foreign exchange market intervention has little enduring influence. Indeed, the dollar's depreciation represents a step toward bringing the U.S. current account deficit to a more sustainable position. However, an abrupt weakening of investor sentiment and turbulent exchange market conditions would have adverse consequences, both domestically and abroad. A firm commitment to reducing the U.S. fiscal deficit over the medium term, as well as strong growth among partner countries, would help to ensure that the eventual adjustment of the U.S. current account deficit is orderly and rests on a strengthening of national saving rather than weaker U.S. investment and growth.

68. The priority for fiscal policy should be to establish a credible framework for returning the budget to balance, excluding Social Security, over the medium term and to place retirement and health care systems on a sound financial footing. Although the deficit/GDP ratio is projected to narrow somewhat in coming years, these projections are based on assumptions - including a sharp improvement in tax receipts and strict limits on discretionary outlays, excluding defense and homeland security — that may prove optimistic, 
especially since supporting policies to ensure strict limits on discretionary spending have yet to be defined. Moreover, the retirement of the baby-boom generation will place increasing pressure on the Social Security and Medicare systems in coming decades, and the unfunded actuarial liability of these programs is substantial. Balancing the budget, excluding Social Security, over the next five to ten years would enable a substantial reduction in the debt ratio ahead of this demographic shift and provide greater room to implement the needed reform of entitlement programs.

69. Tax and expenditure policies will need to be geared toward ensuring a sustainable fiscal position. In this context, the recent tax package has added to uncertainty about the future paths of tax rates and is unlikely to boost output in a sustained manner unless its adverse budgetary impact is offset over the medium term. Meeting the fiscal costs of population aging will eventually require revenue increases - preferably through base broadening measures - and sustained spending restraints.

70. Re-introducing the Budget Enforcement Act (BEA) disciplines would help ensure that these medium-term trade-offs are faced squarely and that policies are consistent with fiscal sustainability. The federal budget is highly transparent and represents best practice in many areas. However, the sharp increase in discretionary spending in recent years, and the use of sunsets and other devices to obscure the longer-term budgetary consequences of tax cuts, have raised questions about the adequacy of fiscal discipline. The BEA disciplines, if restored and strengthened further, could usefully support the fiscal adjustment that is needed in the period ahead, particularly if accompanied by broader efforts to re-establish a political consensus for budget balance.

71. Steps should be initiated soon to strengthen the financial position of the Social Security and Medicare systems. In the case of the Social Security system, relatively modest changes in the system - including amendments to indexation formulas, increases in the retirement age, or hikes in contributions rates - would be sufficient to close projected shortfalls. However, such measures take considerable time to phase in, and the longer decisions are delayed, the larger and more painful the adjustments will be required. The financial position of the Medicare system is considerably worse, given the rapid growth of health care costs and the modest share of benefits that are covered by individual contributions. In these circumstances, any measures to enrich benefits, including for prescription drugs, should be accompanied by credible measures to address the system's longer-term financial problems. Especially in view of the fiscal pressures faced by state and local governments, proposed reforms to Medicaid funding will need to take into account the growing pressures on the system from population aging and its impact on Medicare.

72. Energy policies that operate on the demand-side-as well as the supply-sidewould help support both environmental and fiscal objectives. Current proposals embodied in the Energy Bill aim to boost U.S. energy production and reduce emissions intensity, principally through tax and other incentives for businesses. Measures that directly target consumers - including energy-related taxes — also could be effective in aligning energy 
demand and supply and achieving emissions goals, while contributing to longer-term budgetary objectives.

73. Financial sector balance sheets have held up well, and corporate profitability seems to be recovering. However, care will be needed to ensure that banks are well-positioned to absorb the effect on balance sheets of an eventual turnaround in interest rates or a possible cooling of conditions in the real estate market. In view of the rapid growth and systemic importance of Fannie Mae and Freddie Mac, the authorities will need to monitor closely risk management and accounting practices by these agencies and ensure that disclosure is adequate. There would also seem merit in taking action to further limit these agencies' special status and discourage the market perception of an implicit government guarantee of their liabilities.

74. Considerable progress has been made toward strengthening accounting standards and corporate governance. The remaining challenge is to ensure that the responsible agencies are provided with sufficient resources and support to complete the reform agenda. Key tasks include: pressing ahead with improvements in the accounting of stock options; ensuring the independence of corporate boards; and achieving greater harmony between U.S. and international accounting standards. The significant underfunding of defined-benefit corporate pension plans that has emerged in recent years also points to the need to strengthen the accounting, transparency, and funding of these plans, as well as the finances of the Pension Benefit Guaranty Corporation.

75. The United States should continue to play an important leadership role in promoting trade liberalization. A more open and liberal trade system has enormous potential for fostering growth in all countries, and the United States has already made useful proposals for moving the Doha Round forward. However, concerted efforts will still be needed to find common ground with partner countries in a range of difficult areas, and the authorities are also encouraged to take early action to comply with recent WTO rulings. Ongoing negotiations of bilateral and regional free-trade agreements have the potential to bring substantial benefits to the partner countries involved. At the same time, it is essential that such initiatives complement broader multilateral efforts toward liberalization and are designed in a manner that limits trade diversion and administrative complexities.

76. There are important opportunities to better align U.S. trade and other domestic policies with the broader commitment to development. U.S. development assistance as a share of GNP still remains among the lowest among the industrial countries, and larger increases in foreign assistance would still be desirable. There also remains scope for improving the complementarities between development and trade policies, including by reducing subsidies to U.S. agricultural producers and by more ambitious efforts to eliminate remaining non-tariff barriers to imports from developing countries.

77. It is recommended that the next Article IV consultation take place within the standard 12-month cycle. 
Table 1. G-7: Economic Performance

\begin{tabular}{|c|c|c|c|c|c|c|c|}
\hline & 1996 & 1997 & 1998 & 1999 & 2000 & 2001 & 2002 \\
\hline & \multicolumn{7}{|c|}{ (Annual percent change) } \\
\hline \multicolumn{8}{|l|}{ Per capita GDP } \\
\hline United States & 2.4 & 3.2 & 3.1 & 2.9 & 2.6 & -0.8 & 1.3 \\
\hline Japan & 3.1 & 1.6 & -1.4 & 0.0 & 2.6 & 0.2 & 0.1 \\
\hline Germany & 0.5 & 1.2 & 2.0 & 2.0 & 2.7 & 0.4 & 0.5 \\
\hline Canada & 0.5 & 3.1 & 3.2 & 4.7 & 4.3 & 0.9 & 2.3 \\
\hline France, Italy, and United Kingdom 1 & 1.3 & 2.1 & 2.5 & 2.1 & 3.0 & 1.4 & 0.7 \\
\hline G-7 countries & 2.0 & 2.5 & 2.1 & 2.2 & 2.7 & 0.0 & 1.0 \\
\hline \multicolumn{8}{|l|}{ Real GDP } \\
\hline United States & 3.6 & 4.4 & 4.3 & 4.1 & 3.8 & 0.3 & 2.4 \\
\hline Japan & 3.5 & 1.9 & -1.1 & 0.2 & 2.8 & 0.4 & 0.3 \\
\hline Germany & 0.8 & 1.4 & 2.0 & 2.0 & 2.9 & 0.6 & 0.5 \\
\hline Canada & 1.6 & 4.2 & 4.1 & 5.5 & 5.3 & 1.9 & 3.3 \\
\hline France, Italy, and United Kingdom 1 & 1.6 & 2.4 & 2.8 & 2.4 & 3.4 & 1.8 & 1.1 \\
\hline G-7 countries & 2.2 & 2.7 & 2.2 & 2.4 & 2.9 & 0.2 & 1.1 \\
\hline \multicolumn{8}{|l|}{ Real domestic demand } \\
\hline United States & 3.7 & 4.7 & 5.4 & 5.0 & 4.4 & 0.4 & 3.0 \\
\hline Japan & 4.0 & 0.9 & -1.5 & 0.3 & 2.3 & 1.1 & -0.4 \\
\hline Germany & 0.3 & 0.6 & 2.4 & 2.8 & 1.8 & -0.8 & -0.7 \\
\hline Canada & 0.9 & 5.7 & 2.4 & 4.1 & 5.0 & 1.7 & 3.4 \\
\hline France, Italy, and United Kingdom 1 & 1.5 & 2.4 & 4.1 & 3.4 & 3.5 & 1.9 & 1.4 \\
\hline G-7 countries & 2.8 & 3.1 & 3.5 & 3.6 & 3.6 & 0.8 & 1.7 \\
\hline \multicolumn{8}{|l|}{ GDP deflator } \\
\hline United States & 1.9 & 1.9 & 1.2 & 1.4 & 2.1 & 2.4 & 1.1 \\
\hline Japan & -0.8 & 0.3 & -0.1 & -1.5 & -1.9 & -1.6 & -1.7 \\
\hline Germany & 1.0 & 0.7 & 1.1 & 0.5 & -0.3 & 1.4 & 1.7 \\
\hline Canada & 1.6 & 1.2 & -0.5 & 1.7 & 4.0 & 1.1 & 0.9 \\
\hline France, Italy, and United Kingdom 1 & 3.3 & 2.2 & 2.2 & 1.6 & 1.6 & 2.1 & 2.3 \\
\hline \multirow[t]{2}{*}{ G-7 countries } & 1.6 & 1.5 & 1.1 & 0.9 & 1.2 & 1.5 & 1.0 \\
\hline & \multicolumn{7}{|c|}{ (In percent of GDP) } \\
\hline \multicolumn{8}{|l|}{ General government financial balanc $2 /$} \\
\hline United States & -2.4 & -1.3 & -0.1 & 0.5 & 1.2 & -0.7 & -3.8 \\
\hline Japan & -3.1 & -3.8 & -5.5 & -7.1 & -7.4 & -7.2 & -7.7 \\
\hline Germany & -3.4 & -2.7 & -2.2 & -1.5 & 1.1 & -2.8 & -2.9 \\
\hline Canada & -2.8 & 0.2 & 0.1 & 1.6 & 3.0 & 1.4 & 0.8 \\
\hline France, Italy, and United Kingdom 1 & -5.1 & -2.4 & -1.7 & -0.7 & 0.7 & -0.9 & -2.2 \\
\hline G-7 countries & -3.2 & -2.1 & -1.6 & -1.2 & -0.3 & -1.9 & -3.8 \\
\hline \multicolumn{8}{|l|}{ Gross savings } \\
\hline United States & 17.3 & 18.1 & 18.8 & 18.4 & 18.4 & 16.5 & 15.0 \\
\hline Japan & 30.5 & 30.8 & 29.7 & 28.4 & 28.7 & 27.7 & 26.5 \\
\hline Germany & 21.3 & 21.3 & 21.5 & 20.7 & 20.8 & 19.8 & 20.9 \\
\hline Canada & 18.8 & 19.6 & 19.1 & 20.7 & 23.8 & 22.4 & 21.9 \\
\hline France, Italy, and United Kingdom 1 & 18.9 & 19.5 & 19.8 & 19.5 & 19.2 & 18.9 & 18.2 \\
\hline G-7 countries & 20.5 & 21.0 & 21.2 & 20.6 & 20.8 & 19.5 & 18.5 \\
\hline \multicolumn{8}{|l|}{ Fixed private investmen 1} \\
\hline United States & 15.5 & 16.0 & 16.7 & 17.0 & 17.2 & 16.3 & 15.2 \\
\hline Japan & 19.8 & 20.3 & 19.3 & 18.4 & 19.3 & 19.0 & 17.8 \\
\hline Germany & 19.6 & 19.5 & 19.5 & 19.6 & 19.8 & 18.4 & 17.1 \\
\hline Canada & 15.5 & 17.5 & 17.7 & 17.4 & 17.0 & 17.4 & 17.0 \\
\hline France, Italy, and United Kingdom 1 & 14.9 & 15.0 & 15.4 & 15.7 & 16.1 & 15.9 & 15.0 \\
\hline G-7 countries & 16.6 & 17.0 & 17.2 & 17.3 & 17.6 & 16.9 & 15.9 \\
\hline \multicolumn{8}{|l|}{ Current account balance } \\
\hline United States & -1.5 & -1.5 & -2.3 & -3.1 & -4.2 & -3.9 & -4.6 \\
\hline Japan & 1.4 & 2.2 & 3.0 & 2.6 & 2.5 & 2.1 & 2.8 \\
\hline Germany & -0.8 & -0.4 & -0.9 & -3.0 & -5.0 & 0.6 & 8.4 \\
\hline Canada & 0.5 & -1.3 & -1.2 & 0.3 & 2.9 & 2.4 & 2.0 \\
\hline France, Italy, and United Kingdom 1 & 1.2 & 1.8 & 1.3 & 0.5 & -0.3 & 0.1 & 0.1 \\
\hline G-7 countries & -0.2 & 0.0 & -0.5 & -1.3 & -2.0 & -1.3 & -0.8 \\
\hline
\end{tabular}

Sources: World Economic Outlook database; and IMF staff estimate

1/ Composites for the country groups are averages of individual countries weighted by the average value of the respective GDPs converted using PPP weights over the preceding three years.

2/ On national accounts basis. 
Table 2. United States: Selected Economic Indicators

(Percent change from previous period, unless otherwise indicated)

\begin{tabular}{|c|c|c|c|c|c|c|c|c|c|c|c|c|c|}
\hline & \multirow[b]{3}{*}{1998} & \multirow[b]{3}{*}{1999} & \multirow[b]{3}{*}{2000} & \multirow[b]{3}{*}{2001} & \multirow[b]{3}{*}{2002} & \multirow{3}{*}{$\frac{2003}{\mathrm{Q} 1}$} & \multicolumn{7}{|c|}{ Projections } \\
\hline & & & & & & & \multicolumn{3}{|c|}{2003} & \multicolumn{4}{|c|}{2004} \\
\hline & & & & & & & Q2 & Q3 & Q4 & Q1 & Q2 & Q3 & Q4 \\
\hline \multicolumn{14}{|l|}{ NIPA in constant prices } \\
\hline Real GDP & 4.3 & 4.1 & 3.8 & 0.3 & 2.4 & 1.4 & 1.8 & 3.1 & 3.5 & 3.7 & 3.8 & 4.0 & 4.0 \\
\hline Net exports $1 /$ & -1.2 & -1.0 & -0.8 & -0.2 & -0.6 & 0.8 & -0.3 & -0.5 & -0.4 & -0.1 & 0.1 & 0.2 & 0.4 \\
\hline Total domestic demand & 5.4 & 5.0 & 4.4 & 0.4 & 3.0 & 0.6 & 2.1 & 3.5 & 3.8 & 3.6 & 3.6 & 3.6 & 3.4 \\
\hline Final domestic demand & 5.3 & 5.2 & 4.3 & 1.6 & 2.4 & 1.4 & 2.0 & 1.9 & 2.9 & 2.7 & 2.8 & 3.0 & 2.9 \\
\hline Private final consumption & 4.8 & 4.9 & 4.3 & 2.5 & 3.1 & 2.0 & 2.4 & 2.1 & 3.2 & 2.9 & 2.3 & 2.9 & 2.9 \\
\hline Public consumption expenditure & 1.4 & 2.9 & 2.8 & 3.7 & 4.4 & 0.7 & 2.3 & 1.8 & 1.3 & 1.7 & 4.3 & 1.8 & 1.8 \\
\hline Gross fixed domestic investment & 10.2 & 7.9 & 5.5 & -2.7 & -1.8 & -0.3 & 0.1 & 1.2 & 2.9 & 2.9 & 3.7 & 4.6 & 3.9 \\
\hline Private & 11.4 & 7.8 & 6.1 & -3.8 & -3.1 & -0.2 & 0.3 & 1.7 & 3.8 & 4.0 & 4.5 & 5.6 & 4.7 \\
\hline Public & 4.4 & 8.2 & 2.4 & 3.3 & 4.3 & -0.9 & -1.1 & -1.1 & -1.1 & -2.3 & -0.3 & -0.3 & -0.3 \\
\hline Change in business inventories $1 /$ & 0.2 & -0.2 & 0.1 & -1.2 & 0.6 & -0.8 & 0.1 & -0.1 & 0.0 & 0.0 & 0.0 & 0.0 & 0.0 \\
\hline GDP in current prices & 5.6 & 5.6 & 5.9 & 2.6 & 3.6 & 3.8 & 2.8 & 4.3 & 4.8 & 5.2 & 5.4 & 5.6 & 5.7 \\
\hline \multicolumn{14}{|l|}{ Employment and inflation } \\
\hline Unemployment rate (percent) & 4.5 & 4.2 & 4.0 & 4.8 & 5.8 & 5.8 & 6.0 & 6.1 & 6.1 & 6.0 & 5.9 & 5.8 & 5.7 \\
\hline GDP gap & 0.4 & 1.2 & 1.8 & -1.0 & -1.6 & -2.3 & -2.7 & -2.6 & -2.5 & -2.4 & -2.2 & -2.0 & -1.8 \\
\hline CPI inflation & 1.5 & 2.2 & 3.4 & 2.8 & 1.6 & 3.9 & 0.5 & 1.0 & 1.1 & 1.3 & 1.5 & 1.8 & 1.9 \\
\hline GDP deflator & 1.2 & 1.4 & 2.1 & 2.4 & 1.1 & 2.4 & 1.0 & 1.1 & 1.2 & 1.4 & 1.5 & 1.5 & 1.6 \\
\hline \multicolumn{14}{|l|}{ Financial policy indicators } \\
\hline Unified federal balance $(\$ \mathrm{~b})$ & 69 & 126 & 236 & 127 & -158 & $\ldots$ & $\ldots$ & $\ldots$ & $\ldots$ & $\ldots$ & $\ldots$ & $\ldots$ & $\ldots$ \\
\hline In percent of FY GDP & 0.8 & 1.4 & 2.4 & 1.3 & -1.5 & $\ldots$ & $\ldots$ & $\ldots$ & $\ldots$ & $\ldots$ & $\ldots$ & $\ldots$ & $\ldots$ \\
\hline Central government balance ( $\$ \mathrm{~b}, \mathrm{NIPA})$ & 46 & 110 & 207 & 71 & -218 & $\ldots$ & $\ldots$ & $\ldots$ & $\ldots$ & $\ldots$ & $\ldots$ & $\ldots$ & $\ldots$ \\
\hline In percent of GDP & 0.5 & 1.2 & 2.1 & 0.7 & -2.1 & $\ldots$ & $\ldots$ & $\ldots$ & $\ldots$ & $\ldots$ & $\ldots$ & $\ldots$ & $\ldots$ \\
\hline General government balance ( $\$$ b, NIPA) & -5 & 43 & 116 & -73 & -393 & $\ldots$ & $\ldots$ & $\ldots$ & $\ldots$ & $\ldots$ & $\ldots$ & $\ldots$ & $\ldots$ \\
\hline In percent of GDP & -0.1 & 0.5 & 1.2 & -0.7 & -3.8 & $\ldots$ & $\ldots$ & $\ldots$ & $\ldots$ & $\ldots$ & $\ldots$ & $\ldots$ & $\ldots$ \\
\hline Three-month Treasury bill rate & 4.9 & 4.8 & 6.0 & 3.5 & 1.6 & 1.2 & 1.1 & 1.0 & 1.0 & 1.1 & 1.3 & 1.7 & 2.6 \\
\hline Ten-year government bond rate & 5.3 & 5.6 & 6.0 & 5.0 & 4.6 & 3.9 & 3.6 & 3.5 & 3.6 & 3.7 & 3.8 & 3.9 & 4.5 \\
\hline \multicolumn{14}{|l|}{ Balance of payments } \\
\hline Current account balance $(\$ \mathrm{~b})$ & -205 & -291 & -411 & -394 & -481 & -544 & -536 & -545 & -565 & -569 & -561 & -565 & -546 \\
\hline In percent of GDP & -2.3 & -3.1 & -4.2 & -3.9 & -4.6 & -5.1 & -5.0 & -5.0 & -5.1 & -5.1 & -5.0 & -4.9 & -4.7 \\
\hline Merchandise trade balance $(\$ b)$ & -247 & -346 & -452 & -427 & -485 & -544 & -518 & -527 & -537 & -542 & -540 & -538 & -530 \\
\hline In percent of GDP & -2.8 & -3.7 & -4.6 & -4.2 & -4.6 & -5.1 & -4.8 & -4.8 & -4.9 & -4.9 & -4.8 & -4.7 & -4.6 \\
\hline Export volume 2/ & 2.1 & 3.4 & 9.7 & -5.4 & -1.6 & -1.3 & -5.4 & -1.2 & 4.3 & 8.2 & 10.0 & 11.8 & 14.6 \\
\hline Import volume 2/ & 11.8 & 10.9 & 13.2 & -2.9 & 3.7 & -6.2 & -1.5 & 2.9 & 5.8 & 6.1 & 6.3 & 6.5 & 6.8 \\
\hline Invisibles $(\$$ b) & 42 & 55 & 41 & 33 & 4 & 0 & -18 & -18 & -28 & -27 & -21 & -27 & -16 \\
\hline In percent of GDP & 0.5 & 0.6 & 0.4 & 0.3 & 0.0 & 0.0 & -0.2 & -0.2 & -0.3 & -0.2 & -0.2 & -0.2 & -0.1 \\
\hline \multicolumn{14}{|l|}{ Saving and investment (in percent of GDP) } \\
\hline Gross national saving & 18.8 & 18.4 & 18.4 & 16.5 & 15.0 & 14.0 & 13.4 & 13.6 & 13.8 & 13.6 & 13.7 & 14.1 & 14.2 \\
\hline General government & 3.1 & 3.8 & 4.4 & 2.6 & -0.2 & -1.0 & -2.3 & -2.1 & -2.0 & -2.3 & -1.9 & -1.5 & -1.2 \\
\hline Private & 15.7 & 14.6 & 14.0 & 13.9 & 15.2 & 15.0 & 15.7 & 15.7 & 15.9 & 15.9 & 15.6 & 15.6 & 15.3 \\
\hline Personal & 3.4 & 1.9 & 2.1 & 1.7 & 2.7 & 2.7 & 2.9 & 3.0 & 3.1 & 3.2 & 3.2 & 3.2 & 3.4 \\
\hline Business & 12.2 & 12.7 & 11.9 & 12.2 & 12.5 & 12.3 & 12.7 & 12.7 & 12.7 & 12.7 & 12.3 & 12.3 & 11.9 \\
\hline Gross domestic investment & 20.7 & 20.9 & 21.1 & 19.1 & 18.6 & 18.4 & 18.5 & 18.4 & 18.4 & 18.3 & 18.3 & 18.3 & 18.3 \\
\hline
\end{tabular}

Sources: Haver Analytics; and IMF staff estimates.

$1 /$ Contribution to growth.

2/ NIPA basis, goods and services. 
Table 3. United States: Key Indicators

(Percent change from previous period, unless otherwise indicated)

\begin{tabular}{|c|c|c|c|c|c|c|c|c|c|c|c|c|}
\hline & \multirow[b]{2}{*}{2002} & \multicolumn{4}{|c|}{2002} & \multirow{2}{*}{$\begin{array}{c}2003 \\
\mathrm{Q} 1\end{array}$} & \multirow{2}{*}{$\frac{2002}{\mathrm{Dec}}$} & \multicolumn{5}{|c|}{2003} \\
\hline & & Q1 & Q2 & Q3 & Q4 & & & Jan & Feb & Mar & Apr & May \\
\hline \multicolumn{13}{|l|}{ Production and capacity utilization } \\
\hline \multicolumn{13}{|l|}{ Industrial production } \\
\hline All industries & -0.8 & 0.4 & 1.1 & 0.8 & -0.8 & 0.1 & -0.8 & 0.7 & 0.0 & -0.5 & -0.6 & 0.2 \\
\hline Manufacturing & -1.0 & 0.5 & 0.9 & 0.7 & -1.0 & -0.2 & -1.1 & 0.6 & -0.2 & -0.3 & -0.7 & 0.2 \\
\hline Business equipment & -8.5 & -1.4 & -0.3 & -0.4 & -1.7 & 0.1 & -1.4 & 1.0 & 0.3 & -0.4 & -0.6 & 0.0 \\
\hline Ex hi-tech and motor vehicle and parts & -2.3 & -0.2 & 0.4 & 0.3 & -1.1 & -0.4 & -0.6 & 0.2 & 0.1 & -0.2 & -0.8 & 0.2 \\
\hline \multicolumn{13}{|l|}{ Capacity utilization (index) } \\
\hline All industries & 75.6 & 75.1 & 75.7 & 76.2 & 75.3 & 75.1 & 74.9 & 75.3 & 75.3 & 74.8 & 74.3 & 74.3 \\
\hline Manufacturing & 73.7 & 73.4 & 73.9 & 74.2 & 73.5 & 73.2 & 73.0 & 73.3 & 73.3 & 73.1 & 72.5 & 72.6 \\
\hline \multicolumn{13}{|l|}{ Orders and inventories } \\
\hline Inventory/sales ratio & 1.55 & 1.54 & 1.54 & 1.55 & 1.58 & 1.60 & 1.57 & 1.58 & 1.62 & 1.59 & 1.61 & $\ldots$ \\
\hline Total manufacturers' orders & -0.8 & 0.3 & 0.8 & 1.8 & -0.8 & 1.7 & 0.3 & 1.7 & -1.0 & 2.1 & -2.9 & $\ldots$ \\
\hline \multicolumn{13}{|l|}{ Households } \\
\hline Retail sales & 3.0 & -1.4 & 1.1 & 2.0 & 0.0 & 1.3 & 1.3 & 0.5 & -1.5 & 2.3 & -0.3 & -0.1 \\
\hline Motor vehicle sales & 1.4 & -9.3 & -0.3 & 6.9 & -2.7 & 0.2 & 6.1 & -3.0 & -4.4 & 5.1 & 2.0 & -0.2 \\
\hline Consumer confidence (index) & 96.6 & 101.2 & 108.4 & 95.2 & 81.7 & 68.3 & 80.7 & 78.8 & 64.8 & 61.4 & 81.0 & 83.6 \\
\hline Disposable income & 5.6 & 3.7 & 1.6 & 0.9 & 0.8 & 1.2 & 0.5 & 0.5 & 0.2 & 0.2 & 0.2 & 0.3 \\
\hline Housing starts & 6.9 & 9.3 & -2.0 & 1.1 & 2.4 & -0.3 & 3.1 & 0.7 & -10.3 & 6.2 & -6.3 & 6.1 \\
\hline \multicolumn{13}{|c|}{ Prices (percent change, same period previous year) } \\
\hline CPI & 1.6 & 1.2 & 1.3 & 1.6 & 2.2 & 2.9 & 2.4 & 2.6 & 3.0 & 3.0 & 2.2 & 2.1 \\
\hline Excluding food and energy & 2.3 & 2.5 & 2.4 & 2.3 & 2.1 & 1.8 & 2.0 & 1.9 & 1.9 & 1.7 & 1.5 & 1.6 \\
\hline PPI, finished goods & -1.3 & -2.4 & -2.3 & -1.4 & 1.0 & 3.4 & 1.2 & 2.5 & 3.5 & 4.2 & 2.4 & 2.5 \\
\hline Excluding food and energy & 0.1 & 0.5 & 0.2 & -0.4 & 0.1 & 0.3 & -0.5 & -0.1 & 0.1 & 0.9 & -0.2 & -0.1 \\
\hline PCE price index & 1.4 & 0.9 & 1.1 & 1.6 & 1.8 & 2.2 & 2.0 & 2.1 & 2.3 & 2.4 & 1.8 & 1.7 \\
\hline Excluding food and energy & 1.7 & 1.5 & 1.7 & 2.0 & 1.6 & 1.5 & 1.7 & 1.6 & 1.4 & 1.5 & 1.3 & 1.2 \\
\hline \multicolumn{13}{|l|}{ Labor market } \\
\hline Nonfarm payrolls (millions) & 130.4 & 130.5 & 130.4 & 130.2 & 130.3 & 130.2 & 130.2 & 130.4 & 130.2 & 130.1 & 130.1 & 130.1 \\
\hline Change (millions) & -1.5 & -0.4 & -0.1 & -0.2 & 0.1 & -0.1 & -0.2 & 0.2 & -0.1 & -0.2 & 0.0 & 0.0 \\
\hline Unemployment rate (percent) & 5.8 & 5.6 & 5.8 & 5.8 & 5.9 & 5.8 & 6.0 & 5.7 & 5.8 & 5.8 & 6.0 & 6.1 \\
\hline \multicolumn{13}{|c|}{ Money and credit (percent change, same period previous year) } \\
\hline M1 & 4.8 & 7.6 & 5.9 & 2.5 & 3.3 & 3.8 & 3.3 & 2.9 & 4.1 & 4.2 & 5.6 & 6.4 \\
\hline M2 & 7.6 & 9.2 & 7.5 & 7.1 & 6.8 & 6.7 & 6.4 & 6.5 & 6.7 & 6.9 & 7.6 & 8.0 \\
\hline Bank lending & 4.6 & 2.6 & 3.1 & 5.4 & 7.1 & 9.7 & 8.3 & 8.7 & 9.9 & 10.6 & 10.7 & 11.3 \\
\hline Current account ( $\$$ billions) & -480.9 & -426.9 & -491.3 & -490.9 & -514.3 & -544.4 & $\ldots$ & $\ldots$ & $\ldots$ & $\ldots$ & $\cdots$ & ... \\
\hline Percent of GDP & -4.6 & -4.1 & -4.7 & -4.7 & -4.9 & -5.1 & $\ldots$ & $\ldots$ & $\ldots$ & $\ldots$ & $\ldots$ & $\ldots$ \\
\hline Merchandise trade balance ( $\$$ billions) $1 /$ & -482.9 & -424.1 & -485.1 & -493.2 & -529.0 & -544.0 & -569.4 & -538.3 & -523.8 & -570.1 & -558.9 & ... \\
\hline Exports ( $\$$ billions) & 681.9 & 661.2 & 685.7 & 697.3 & 683.4 & 693.0 & 669.3 & 685.7 & 694.9 & 699.6 & 686.7 & $\ldots$ \\
\hline Price & -0.5 & -0.3 & 0.6 & 0.8 & 0.2 & 0.8 & -0.1 & 0.5 & 1.4 & -1.0 & -0.2 & $\ldots$ \\
\hline Volume & -3.6 & -0.9 & 3.8 & 1.0 & -3.0 & 0.0 & -3.3 & 1.6 & 0.1 & 1.9 & -1.6 & $\ldots$ \\
\hline Imports (\$ billions) & $1,164.7$ & $1,085.3$ & $1,170.8$ & $1,190.5$ & $1,212.3$ & $1,237.0$ & $1,238.6$ & $1,224.0$ & $1,218.7$ & $1,269.6$ & $1,245.6$ & $\ldots$ \\
\hline Price & -1.7 & -0.5 & 2.6 & 0.7 & 0.2 & 2.9 & 0.4 & 1.9 & 1.7 & 2.2 & -2.6 & $\ldots$ \\
\hline Volume & 3.9 & 0.9 & 6.3 & 0.8 & 1.5 & -1.9 & 1.0 & -3.0 & -2.1 & 1.9 & 0.7 & $\ldots$ \\
\hline
\end{tabular}

Sources: Haver Analytics; and IMF staff estimates.

1/ Monthly data derived from Census data; quarterly volume and prices derived from NIPAs; current values obtained from BOP. 
Table 4. United States: Balance of Payments

\begin{tabular}{|c|c|c|c|c|c|c|c|}
\hline & 1996 & 1997 & 1998 & 1999 & 2000 & 2001 & 2002 \\
\hline Current account & -117 & -128 & -205 & -291 & -411 & -394 & -481 \\
\hline Percent of GDP & -1.5 & -1.5 & -2.3 & -3.1 & -4.2 & -3.9 & -4.6 \\
\hline Goods and services & -103 & -107 & -163 & -261 & -375 & -358 & -418 \\
\hline Merchandise trade & -191 & -198 & -247 & -346 & -452 & -427 & -483 \\
\hline Exports & 612 & 678 & 670 & 684 & 772 & 719 & 682 \\
\hline Imports & -803 & -876 & -917 & $-1,030$ & $-1,224$ & $-1,146$ & $-1,165$ \\
\hline Services & 88 & 91 & 84 & 85 & 77 & 69 & 65 \\
\hline Receipts & 239 & 256 & 262 & 282 & 298 & 289 & 292 \\
\hline Payment & -151 & -164 & -179 & -197 & -221 & -219 & -227 \\
\hline Investment income & 25 & 21 & 7 & 17 & 20 & 11 & -4 \\
\hline Receipts & 226 & 261 & 259 & 290 & 347 & 277 & 256 \\
\hline Payment & -202 & -240 & -252 & -273 & -327 & -267 & -260 \\
\hline Unilateral transfers & -39 & -41 & -48 & -47 & -56 & -47 & -59 \\
\hline Government transfers & -15 & -12 & -13 & -14 & -17 & -12 & -17 \\
\hline Private transfers & -23 & -29 & -35 & -33 & -39 & -35 & -42 \\
\hline $\begin{array}{l}\text { Capital account } \\
\text { transactions, net }\end{array}$ & -1 & -1 & -1 & -5 & -1 & -1 & -1 \\
\hline Financial account & 137 & 219 & 76 & 237 & 456 & 416 & 528 \\
\hline Private capital & 5 & 201 & 103 & 182 & 420 & 416 & 437 \\
\hline Direct investment & -5 & 1 & 36 & 65 & 162 & 32 & -98 \\
\hline Outflows & -92 & -105 & -143 & -225 & -159 & -120 & -138 \\
\hline Inflows & 87 & 106 & 179 & 289 & 321 & 152 & 40 \\
\hline Securities & 118 & 198 & 77 & 161 & 258 & 338 & 425 \\
\hline Outflows & -150 & -119 & -124 & -116 & -122 & -85 & 16 \\
\hline Inflows & 268 & 317 & 202 & 277 & 379 & 423 & 409 \\
\hline Net U.S. bank flows & -75 & 8 & 4 & -22 & -32 & -17 & 70 \\
\hline Nonbank capital & -33 & -5 & -15 & -21 & 32 & 62 & 40 \\
\hline U.S. official reserves & 7 & -1 & -7 & 9 & 0 & -5 & -4 \\
\hline Foreign official assets & 127 & 19 & -20 & 44 & 38 & 5 & 95 \\
\hline Other items & -1 & 0 & 0 & 3 & -1 & 0 & 0 \\
\hline Statistical discrepancy & -19 & -90 & 130 & 59 & -44 & -21 & -46 \\
\hline
\end{tabular}

Source: Haver Analytics. 
Table 5. United States: Fiscal Indicators, FY 2001-FY 2008

(Fiscal years, in percent of GDP, unless otherwise indicated)

\begin{tabular}{|c|c|c|c|c|c|c|c|c|}
\hline & $\begin{array}{l}2001 \\
\text { actual }\end{array}$ & $\begin{array}{l}2002 \\
\text { actual }\end{array}$ & 2003 & 2004 & 2005 & 2006 & 2007 & 2008 \\
\hline \multicolumn{9}{|c|}{ FY 2004 Budget, Current Services Baseline } \\
\hline Outlays & 18.6 & 19.4 & 19.8 & 19.4 & 19.2 & 19.1 & 18.6 & 18.5 \\
\hline Debt service & 2.1 & 1.7 & 1.5 & 1.5 & 1.6 & 1.6 & 1.6 & 1.6 \\
\hline Other & 16.5 & 17.8 & 18.3 & 17.8 & 17.5 & 17.5 & 17.0 & 16.9 \\
\hline Revenue & 19.9 & 17.9 & 17.3 & 18.0 & 18.8 & 18.8 & 18.8 & 18.9 \\
\hline Unified balance & 1.3 & -1.5 & -2.5 & -1.4 & -0.3 & -0.3 & 0.2 & 0.4 \\
\hline Primary balance & 3.3 & 0.1 & -1.0 & 0.1 & 1.3 & 1.4 & 1.8 & 1.9 \\
\hline Unified balance exc. social security & -0.3 & -3.1 & -3.9 & -2.9 & -2.0 & -1.9 & -1.5 & -1.4 \\
\hline Net debt held by the public & 33.1 & 33.0 & 33.8 & 33.5 & 32.1 & 30.7 & 28.9 & 27.0 \\
\hline \multicolumn{9}{|c|}{ FY 2004 Budget, Current Services Baseline Adjusted for Staff's Economic Assumptions } \\
\hline Outlays & 18.6 & 19.4 & 19.9 & 19.5 & 19.4 & 18.8 & 18.3 & 18.2 \\
\hline Debt service & 2.1 & 1.7 & 1.5 & 1.5 & 1.7 & 1.5 & 1.5 & 1.6 \\
\hline Other & 16.5 & 17.8 & 18.4 & 18.0 & 17.6 & 17.4 & 16.8 & 16.7 \\
\hline Revenue & 19.9 & 17.9 & 17.4 & 18.0 & 18.7 & 18.6 & 18.6 & 18.7 \\
\hline Unified balance & 1.3 & -1.5 & -2.5 & -1.4 & -2.0 & -0.2 & 0.3 & 0.4 \\
\hline Primary balance & 3.3 & 0.1 & -1.0 & 0.1 & 1.1 & 1.2 & 1.8 & 2.0 \\
\hline Unified balance exc. social security & -0.3 & -3.1 & -4.0 & -3.0 & 2.0 & -1.9 & -1.5 & -1.3 \\
\hline Net debt held by the public & 33.1 & 33.0 & 34.0 & 33.7 & 32.2 & 30.5 & 28.4 & 26.4 \\
\hline \multicolumn{9}{|c|}{ FY 2004 Administration Budget } \\
\hline Outlays & 18.6 & 19.4 & 20.0 & 19.8 & 19.7 & 19.7 & 19.6 & 19.7 \\
\hline Debt service & 2.1 & 1.7 & 1.6 & 1.6 & 1.7 & 1.7 & 1.7 & 1.7 \\
\hline Other & 16.5 & 17.8 & 18.4 & 18.2 & 18.0 & 18.0 & 17.9 & 18.0 \\
\hline Revenue & 19.9 & 17.9 & 16.9 & 16.8 & 17.9 & 18.2 & 18.4 & 18.5 \\
\hline Unified balance & 1.3 & -1.5 & -3.1 & -3.0 & -1.8 & -1.5 & -1.2 & -1.2 \\
\hline Primary balance & 3.3 & 0.1 & -1.5 & -1.4 & 0.1 & 0.3 & 0.5 & 0.4 \\
\hline Unified balance exc. social security & -0.3 & -3.1 & -4.6 & -4.6 & -3.5 & -3.1 & -2.9 & -3.0 \\
\hline Unified balance (in billions of dollars) & 127 & -158 & -333 & -344 & -215 & -182 & -155 & -167 \\
\hline Net debt held by the public & 33.1 & 33.0 & 34.5 & 35.7 & 35.7 & 35.3 & 34.7 & 34.1 \\
\hline \multicolumn{9}{|c|}{ FY 2004 Budget, Adjusted for Staff's Economic and Budget Assumptions } \\
\hline Outlays & 18.6 & 19.4 & 20.9 & 20.8 & 20.2 & 19.9 & 19.9 & 19.9 \\
\hline Debt service & 2.1 & 1.7 & 1.6 & 1.6 & 1.6 & 1.6 & 1.7 & 1.8 \\
\hline Other & 16.5 & 17.8 & 19.3 & 19.1 & 18.6 & 18.3 & 18.2 & 18.1 \\
\hline Revenue & 19.9 & 17.9 & 16.9 & 16.8 & 17.8 & 18.0 & 18.1 & 18.1 \\
\hline Unified balance & 1.3 & -1.5 & -4.0 & -4.0 & -2.4 & -2.0 & -1.9 & -1.8 \\
\hline Primary balance & 3.3 & 0.1 & -2.5 & -2.3 & -0.8 & -0.4 & -0.1 & 0.0 \\
\hline Unified balance exc. social security & -0.3 & -3.1 & -5.5 & -5.5 & -4.0 & -3.6 & -3.6 & -3.6 \\
\hline Unified balance (in billions of dollars) & 127 & -158 & -433 & -446 & -283 & -246 & -248 & -252 \\
\hline Net debt held by the public & 33.1 & 33.0 & 35.5 & 37.7 & 38.0 & 37.8 & 37.4 & 37.2 \\
\hline \multicolumn{9}{|l|}{ Memorandum items: } \\
\hline Structural unified balance $1 /$ & 1.3 & -1.2 & -3.5 & -3.4 & -2.0 & -1.8 & -1.8 & -1.8 \\
\hline Structural unified balance, current services 2/ & 1.3 & -1.2 & -1.9 & -0.9 & 0.0 & 0.0 & 0.3 & 0.5 \\
\hline \multicolumn{9}{|c|}{ Administration's economic projections (in percent, $\mathrm{CY}$ basis) } \\
\hline Real GDP growth & 0.3 & 2.4 & 2.9 & 3.6 & 3.5 & 3.3 & 3.2 & 3.1 \\
\hline CPI inflation & 2.8 & 1.6 & 2.2 & 2.1 & 2.1 & 2.2 & 2.2 & 2.3 \\
\hline Three-month Treasury bill rate & 3.4 & 1.6 & 1.6 & 3.3 & 4.0 & 4.2 & 4.2 & 4.3 \\
\hline
\end{tabular}

Sources: Fiscal Year 2004 Budget of the U.S. Government, and IMF staff estimates.

$1 /$ As a percent of potential GDP, based on proposed measures, under IMF staff's economic assumptions.

2/ As a percent of potential GDP, based on current services estimates, under IMF staff's economic assumptions. 


\section{Table 6. United States: Indicators of External and Financial Vulnerability}

(In percent of GDP, unless otherwise indicated)

\begin{tabular}{|c|c|c|c|c|c|c|c|}
\hline & 1996 & 1997 & 1998 & 1999 & 2000 & 2001 & 2002 \\
\hline \multicolumn{8}{|l|}{ External indicators } \\
\hline Exports of goods and services (percent change, BOP basis) & 7.2 & 9.8 & -0.1 & 2.6 & 11.8 & -5.8 & -3.3 \\
\hline Imports of goods and services (percent change, BOP basis) & 7.3 & 9.1 & 5.3 & 11.3 & 18.5 & -5.5 & 2.0 \\
\hline Terms of trade (percent change) & -0.5 & 1.1 & 2.9 & -2.1 & -4.6 & 2.8 & 1.5 \\
\hline Current account balance & -1.5 & -1.5 & -2.3 & -3.1 & -4.2 & -3.9 & -4.6 \\
\hline Capital and financial account balance & 0.2 & 0.3 & 0.1 & 0.2 & 0.5 & 0.4 & 0.5 \\
\hline Of which: Inward portfolio investment (debt securities, etc.) & 3.2 & 3.5 & 2.1 & 2.7 & 3.9 & 4.0 & 3.7 \\
\hline Inward foreign direct investment & 1.1 & 1.3 & 2.0 & 3.1 & 3.3 & 1.5 & 0.4 \\
\hline Other investment liabilities (net) & 0.2 & 1.8 & 0.5 & 0.6 & 1.2 & 1.2 & 0.9 \\
\hline Official reserves (in billions of dollars) & 75.1 & 70.0 & 81.8 & 71.5 & 67.6 & 68.7 & 79.0 \\
\hline Broad money (M3) to reserves ratio & 90.8 & 110.4 & 126.5 & 145.5 & 170.2 & 184.3 & 205.2 \\
\hline Central bank foreign liabilities (in billions of dollars) & 0.2 & 0.5 & 0.2 & 0.1 & 0.3 & 0.1 & 0.1 \\
\hline Official reserves in months of imports & 0.9 & 0.8 & 0.9 & 0.7 & 0.6 & 0.6 & 0.7 \\
\hline Net international investment position (in billions of dollars) $1 /$ & -521.5 & -833.2 & -918.7 & -797.6 & $-1,387.7$ & $-1,979.9$ & $-2,387.2$ \\
\hline Of which: General government debt (in billions of dollars) 2/ & $1,071.9$ & $1,198.8$ & $1,231.8$ & $1,156.5$ & $1,150.9$ & $1,187.8$ & $1,401.6$ \\
\hline External debt-to-exports ratio & 0.6 & 0.9 & 1.0 & 0.8 & 1.3 & 2.0 & 2.5 \\
\hline External interest payments to exports (in percent) $3 /$ & 19.1 & 20.4 & 22.1 & 22.1 & 24.6 & 23.9 & 20.7 \\
\hline Nominal effective exchange rate (percent change) & 5.1 & 8.1 & 7.8 & -1.3 & 3.4 & 6.4 & -0.6 \\
\hline \multicolumn{8}{|l|}{ Financial market indicators } \\
\hline General government gross debt & 72.4 & 68.9 & 65.9 & 62.7 & 57.1 & 57.0 & 58.8 \\
\hline Three-month Treasury bill yield (percent) & 5.1 & 5.2 & 4.9 & 4.8 & 6.0 & 3.5 & 1.6 \\
\hline Three-month Treasury bill yield (percent, real) & 2.1 & 2.8 & 3.3 & 2.5 & 2.5 & 0.6 & 0.1 \\
\hline Stock market index (S\&P500 percent change in year average) & 23.9 & 30.1 & 24.2 & 22.3 & 7.6 & -16.4 & -16.5 \\
\hline \multicolumn{8}{|l|}{ Banking sector risk indicators (percent unless otherwise indicated) 4/ } \\
\hline Total assets (in billions of dollars) & $4,878.3$ & $5,014.9$ & $5,442.5$ & $5,735.2$ & $6,244.6$ & $6,569.2$ & $7,075.0$ \\
\hline Total loans and leases to assets & 57.6 & 59.2 & 59.5 & 60.9 & 61.2 & 59.3 & 58.8 \\
\hline Total loans to deposits & 87.9 & 86.8 & 88.0 & 91.1 & 91.4 & 88.7 & 88.7 \\
\hline Problem loans to total loans and leases 5/ & 1.0 & 1.0 & 1.0 & 1.0 & 1.1 & 1.4 & 1.5 \\
\hline Assets of troubled banks to total bank assets & 0.1 & 0.1 & 0.1 & 0.1 & 0.3 & 0.5 & 0.5 \\
\hline \multicolumn{8}{|l|}{ Loss allowance to: } \\
\hline Total loans and leases & 1.9 & 1.8 & 1.8 & 1.7 & 1.7 & 1.9 & 1.9 \\
\hline Noncurrent loans and leases & 183.5 & 191.6 & 183.2 & 178.1 & 149.4 & 131.0 & 127.1 \\
\hline Return on equity & 14.5 & 14.7 & 13.9 & 15.3 & 14.0 & 13.1 & 14.5 \\
\hline Return on assets & 1.2 & 1.2 & 1.2 & 1.3 & 1.2 & 1.2 & 1.3 \\
\hline Total capital ratio & 12.5 & 12.2 & 12.2 & 12.2 & 12.1 & 12.7 & 12.8 \\
\hline Core capital ratio & 7.6 & 7.6 & 7.5 & 7.8 & 7.7 & 7.8 & 7.8 \\
\hline
\end{tabular}

Sources: Haver Analytics; Board of Governors of the Federal Reserve System; U.S. Department of Commerce, Bureau of Economic Analysis; and Federal Deposit Insurance Corporation.

$1 /$ Current cost valuation.

2/ Foreign official assets (U.S. Government securities plus Treasury securities).

3/ External interest payments: income payments on foreign-owned assets (other private payments plus U.S. government payments).

4/ FDIC-insured commercial banks.

5/ Noncurrent loans and leases. 
United States: Fund Relations

(As of April 30, 2003)

I. Membership Status: Joined 12/27/45; Article VIII

II. General Resources Account:

Quota

Fund holdings of currency

Reserve position in Fund

Financial Transaction Plan transfers (net)

III. SDR Department:

Net cumulative allocation

Holdings
SDR Million

$37,149.30$

$20,713.66$

$16,430.16$

429.00

SDR Million

$4,899.53$

$8,292.34$
Percent

Quota

100.0

55.8

44.2

Percent

Allocation

100.0

169.3

IV. Outstanding Purchases and Loans: None

V. Financial Arrangements: None

VI. Projected Obligations to Fund: None

VII. Payments Restrictions: The United States has notified the Fund under Decision No. 144 of restrictions on payments and transfers for current international transactions to Libya, Iraq, North Korea, Cuba, and Iran. The United States restricts the sale of arms and petroleum to the National Union for the Total Independence of Angola (UNITA) and to the territory of Angola and has prohibitions against transactions with terrorists and international narcotics traffickers. The United States notified the Fund under Decision No. 144 on August 2, 1995 of the imposition of further restrictions on current transactions with Iran (EBS/95/107).

VIII. Statistical Issues: The quality, coverage, periodicity, and timeliness of U.S. economic data are considered to be good both in the context of the Article IV consultation and for purposes of ongoing surveillance (see Attachment for a summary). The United States has subscribed to the Special Data Dissemination Standard (SDDS) and its metadata are posted on the Dissemination Standard Bulletin Board (DSBB). 


\begin{tabular}{|c|c|c|c|c|c|c|c|}
\hline$\overline{\bar{c}}$ & 啇 & 㖺 & 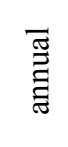 & $\begin{array}{l}0 \\
0\end{array}$ & 爱 & 总 & 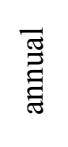 \\
\hline 啇 & 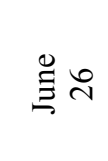 & $\begin{array}{l}\text { 䇏 } \\
\text { 峷 }\end{array}$ & 言 & 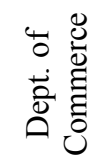 & 言 & 高 & 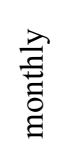 \\
\hline 恿爱 & 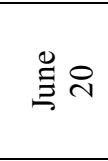 & 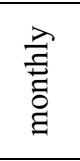 & 言 & 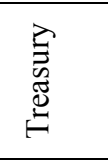 & 言 & 竒 & 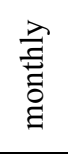 \\
\hline 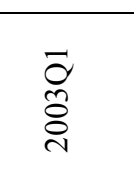 & 弟 & $\begin{array}{l}\text { 苇 } \\
\text { 訔 }\end{array}$ & 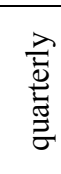 & 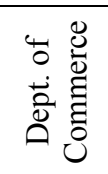 & 䜌 & 郑 & 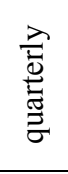 \\
\hline 要愛 & $\stackrel{0}{\underline{\underline{I}}}=$ & 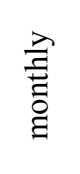 & 言 & 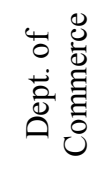 & 产 & 郑 & 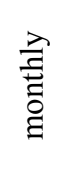 \\
\hline 恿言 & $\underline{\underline{\underline{y}}}=$ & 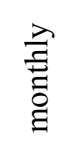 & 言 & 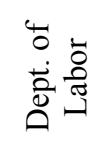 & 产 & 咲 & 辛 \\
\hline 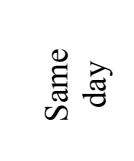 & 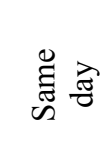 & 䆣 & 衰 & 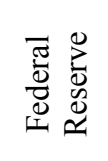 & 言 & 总 & 誓 \\
\hline 兽年 & 善 & 章 & 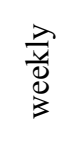 & 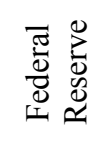 & 産 & 总 & 章 \\
\hline 盖成 & 善 & 瘘 & 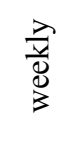 & 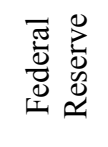 & 产 & 总 & 㫘 \\
\hline 善学 & 駡 & 章 & 窎 & 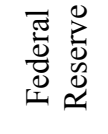 & 흥 & 受 & 章 \\
\hline 善品 & 总恣 & 章 & 童竞 & 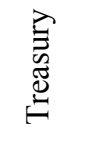 & 产 & 奇 & 章 \\
\hline 善嵒 & 善要 & 差 & 言 & 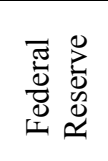 & 言 & 竒 & 产 \\
\hline
\end{tabular}

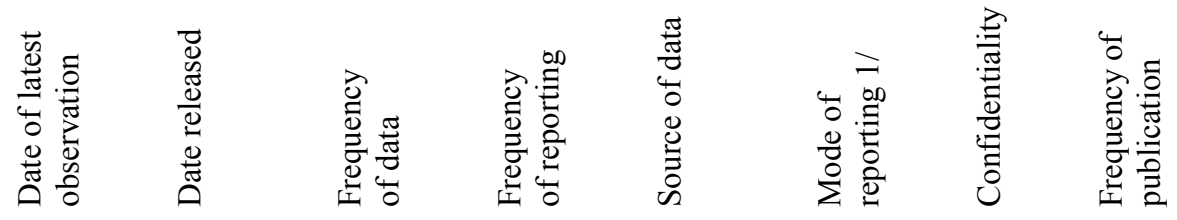




\section{United States-Debt Sustainability}

1. This appendix subjects projections for U.S. public debt and net external liabilities to a series of macroeconomic stress tests. ${ }^{1}$ Following the methodology prescribed in “Assessing Sustainability," SM/02/166 (May 28, 2002), a baseline trajectory for these two debt variables is determined by setting key macroeconomic variables, including the primary fiscal deficit and the non-interest current account balance, at their average rates for the last ten years. The fiscal baseline is then subjected to two-standard deviation shocks in domestic interest rates, real growth and the primary fiscal deficit, each lasting two years before the variable returns to normal. For external debt, similar shocks are assumed for real growth, domestic prices, the foreign interest rate, and the non-interest current account balance.

2. The exercise focuses on short- to medium-term vulnerabilities for the general government. Accordingly, net general government debt is defined by combining the net financial liabilities of federal, state, and local government debt to the public (that is, excluding government debt held by the social insurance trust funds). Under the baseline, the general government primary fiscal deficit is set at 2.2 percent of GDP-i.e., the average of almost a decade of fiscal consolidation and considerably more optimistic than the staff's actual fiscal forecast. ${ }^{2}$ Correspondingly, net general government debt is projected to decline to below 50 percent of GDP by 2008 (Figure 1a).

\section{Shocks to the fiscal baseline do not lead to a reversal in the downward path of} public debt. Under each shock, the debt-to-GDP ratio returns to a downward trajectory after an initial jump in the first two years. The greatest vulnerability is with regard to interest rates and real GDP growth - both shocks induce a temporary increase in the debt ratio in 2003 and 2004 and leave the 2008 ratio more than 10 percent of GDP above the baseline.

\section{Shocks to the external baseline all imply a faster accumulation of foreign debt by} 2008 (Figure 1b). In the baseline scenario, the ratio of net external liabilities to GDP increases from 22 percent in 2002 to 32 percent in 2008. Interest rates would again have the largest influence on debt accumulation, but external debt would reach above 40 percent of GDP in all simulated cases. These simulations reflect the higher historical volatility of the external variables, which increases the magnitude of the two standard deviation shocks.

\section{In addition to these stress tests, a vector autoregression (VAR) model was also} considered, which broadly confirmed the results of the standard stress tests above. ${ }^{3}$ The VAR approach has the advantage of providing a statistically-driven forecast of the debt ratios

\footnotetext{
${ }^{1}$ Net external liabilities equal the U.S. net international investment position.

${ }^{2}$ The baseline also projects real GDP growth of 3.3 percent through 2008; inflation would average 2 percent; and the real interest rate on general government debt is projected at $4 \frac{1}{2}$ percent.

${ }^{3}$ The VAR model for public debt includes the ratio of primary government deficit-to-GDP, real GDP, inflation, real effective exchange rate, three-month, and 10-year interest rates. The model for external debt has the same variables, except that it replaces the primary deficit with the current account balance.
} 
along with an explicit confidence interval for the outcome. The projections confirm the underlying trends in public and external debt, especially the upward trend in net external liabilities. The results also illustrate the considerable uncertainty that attaches to such projections - for the government debt projections the two standard deviation range was roughly plus or minus 15 percent of GDP by 2008, and for external debt the confidence interval was roughly plus or minus 10 percent of GDP.
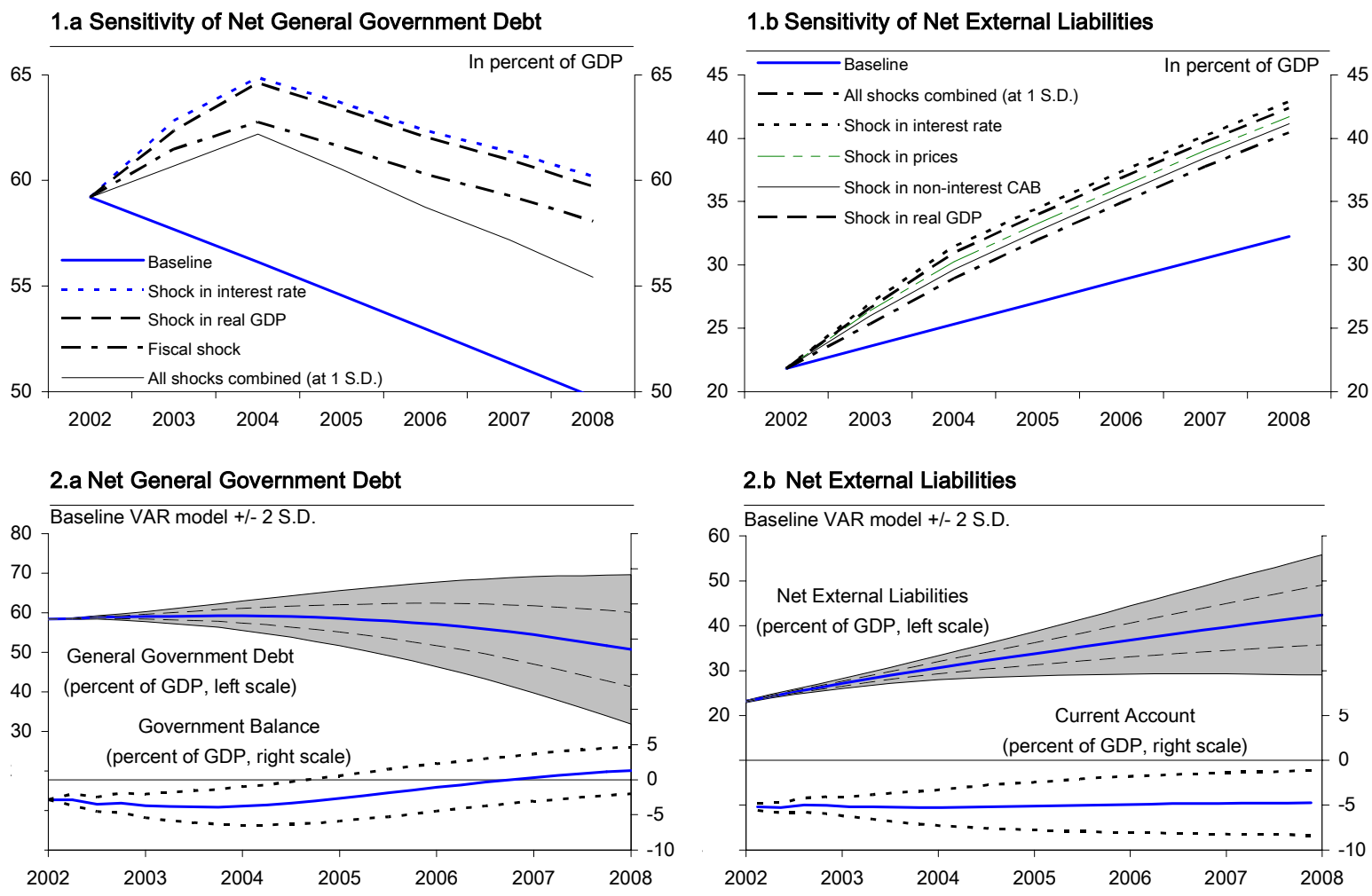


\title{
INTERNATIONAL MONETARY FUND
}

\section{UNITED STATES OF AMERICA \\ Staff Report for the 2003 Article IV Consultation Supplementary Information}

\author{
Prepared by the Western Hemisphere Department \\ Approved by Charles Collyns
}

July 29, 2003

1. This supplement reports on information that has become available since the staff report (SM/03/239) was issued. Topics covered include recent economic and financial developments, the Federal Reserve's Monetary Policy Report to Congress, and the Administration's Mid-Session Review of the Budget. These developments do not affect the staff appraisal.

\section{Recent economic and financial market developments}

2. Recent indicators are broadly consistent with the staff and consensus projections for the economy to gather momentum in the second half of 2003. Manufacturing production rose by 0.4 percent in June, following a 0.1 percent increase in May, reflecting strength in the output of both consumer goods and business equipment. Retail sales rose in June by 0.5 percent, and by 0.7 percent excluding automobiles. A 5.3 percent increase in housing starts in June suggests that residential investment will strengthen in the third quarter. Durable goods orders also rose by 2.1 percent, albeit partly reflecting the effects of a large order for passenger airplanes. The drop in initial jobless claims in early July, as well as recent diffusion indices of employment intentions, indicate that employment conditions are beginning to turn around. However, consumer confidence fell sharply in July and net external demand still appears weak, with the May trade deficit rising further to $\$ 41.8$ billion, as export volumes remain at a low level (especially of capital goods) and import volumes have continued to strengthen.

3. Inflation remains subdued. Although the consumer price index rose 0.2 percent in June, this increase largely reflected the effects of higher gasoline and food prices. The core index was unchanged, however, and increased by only 0.9 percent (annual rate) during the first half of the year.

4. $\quad$ Financial markets developments have reflected improved confidence in the U.S. recovery. Yields on the 10-year Treasury bonds, which had fallen to 3.1 percent in mid-June, have since rebounded to over $4 \frac{1}{4}$ percent, reflecting market perceptions that deflation risks, 
and the possibility that the Federal Reserve might intervene to lower longer-term yields, had diminished. Stock prices have been mixed in recent weeks.

\section{Monetary Policy Report to Congress}

5. The Federal Reserve Board's semi-annual Monetary Policy Report was presented to the Congress on July 15. The macroeconomic projections contained in the report showed real GDP growth rebounding strongly from 21/4-23/4 percent in 2003 (fourth quarter to fourth quarter) to $3 \frac{3}{4}-4 \frac{3}{4}$ percent in 2004 , although the unemployment rate would remain in the range of 6-6 $1 / 4$ percent in both years. ${ }^{1}$ Inflation - as measured by the price index for personal consumption expenditure (PCE) - was projected to remain at $1 \frac{1}{4}-1 \frac{1}{2}$ percent in 2003 and $1-1 \frac{1}{2}$ percent in 2004.

\section{In his testimony, Chairman Greenspan signaled that policy would remain} accommodative as long as needed. He noted that there were several reasons to suggest that economic activity would pick up in coming quarters, including the support to demand provided by low interest rates and the housing market; the lift to disposable incomes expected from the recent tax cuts; and signs that investment was beginning to rebound. However, he also flagged that downside risks remained, highlighting the surge in natural gas prices and lethargic growth among partner countries. Although deflation risks were characterized as remote, he stressed the importance of preventing too low an inflation rate and that "the FOMC stood ready to maintain a highly accommodative stance of policy for as long as it takes to achieve a return to satisfactory economic performance."

\section{Mid-Session Review of the Budget}

7. The Administration's Mid-Session Review (MSR) of the Budget was released on July 15 and showed a marked further deterioration in the budget position (Table 1). Mainly reflecting a further weakening of revenue buoyancies, increased military spending, and greater-than-expected front-loading of the Jobs and Growth Act, the deficits expected in FY 2003 and FY 2004 were raised to 41/4 percent of GDP, roughly 11/4 percentage points higher than the projections released in February. The deficit is still forecast to fall sharply in subsequent years, based on the assumption of strict limits on non-defense spending and a rebound in revenues. Nonetheless, the deficit is expected to remain at $13 / 4$ percent of GDP in FY 2008, roughly $1 / 2$ percentage point higher than previously anticipated.

8. The MSR continued to characterize the fiscal situation as manageable. While acknowledging that the deficit was large and a legitimate cause for concern, the MSR noted that the deficits projected were "well below the postwar peak of 6.0 percent of GDP."

\footnotetext{
${ }^{1}$ The mid-point of the FOMC's growth projection for 2004 is roughly $1 / 2$ percentage point higher than the staff's projection.
} 


\section{Government-sponsored enterprises}

9. An internal investigation of accounting irregularities at Freddie Mac — which had been commissioned by the enterprise's Board - was released in July, following the removal in June of several senior officers of the company. The report raised concerns regarding accounting policy and the reporting of specific derivatives transactions, the adequacy of internal control, governance practices, and disclosure policies. While the report suggested that there had been an inappropriate emphasis on transactions geared toward "income smoothing," it did not suggest that this had adversely affected risk management. A House subcommittee, as well as the Securities and Exchange Commission, are investigating these issues, which have also prompted legislative proposals to replace the Office of Federal Housing Enterprise Oversight with a new agency under the Treasury Department. 
Table 1. United States: Fiscal Indicators, FY 2003-08

(Fiscal years, in percent of GDP except where noted otherwise)

\begin{tabular}{|c|c|c|c|c|c|c|}
\hline & 2003 & 2004 & 2005 & 2006 & 2007 & 2008 \\
\hline \multicolumn{7}{|c|}{ FY 2004 Budget } \\
\hline Outlays & 20.0 & 19.8 & 19.7 & 19.7 & 19.6 & 19.7 \\
\hline Debt service & 1.6 & 1.6 & 1.7 & 1.7 & 1.7 & 1.7 \\
\hline Other & 18.4 & 18.2 & 18.0 & 18.0 & 17.9 & 18.0 \\
\hline Revenue & 16.9 & 16.8 & 17.9 & 18.2 & 18.4 & 18.5 \\
\hline Unified balance & -3.1 & -3.0 & -1.8 & -1.5 & -1.2 & -1.2 \\
\hline Primary balance & -1.5 & -1.4 & -0.1 & 0.3 & 0.5 & 0.4 \\
\hline Unified balance exc. social security & -4.6 & -4.6 & -3.5 & -3.1 & -2.9 & -3.0 \\
\hline Debt held by the public & 34.5 & 35.7 & 35.7 & 35.3 & 34.7 & 34.1 \\
\hline \multicolumn{7}{|c|}{ FY 2004 Budget, Mid-Session Review } \\
\hline Outlays & 20.6 & 20.2 & 19.8 & 19.7 & 19.7 & 19.8 \\
\hline Debt service & 1.5 & 1.7 & 1.8 & 1.7 & 1.8 & 1.8 \\
\hline Other & 19.0 & 18.5 & 18.0 & 18.0 & 17.9 & 17.9 \\
\hline Revenue & 16.3 & 15.9 & 17.2 & 17.8 & 18.1 & 18.1 \\
\hline Unified balance & -4.2 & -4.2 & -2.6 & -1.9 & -1.6 & -1.6 \\
\hline Primary balance & -2.7 & -2.6 & -0.8 & -0.2 & 0.2 & 0.2 \\
\hline Unified balance exc. social security & -5.7 & -5.8 & -4.2 & -3.6 & -3.4 & -3.5 \\
\hline Debt held by the public & 35.7 & 38.1 & 38.7 & 38.7 & 38.4 & 38.1 \\
\hline \multicolumn{7}{|c|}{ Memorandum items: } \\
\hline \multicolumn{7}{|c|}{ Administration's economic assumptions (in percent, calendar-year basis): } \\
\hline Real GDP growth (year over year) & 2.3 & 3.7 & 3.6 & 3.4 & 3.2 & 3.1 \\
\hline Real GDP growth (fourth quarter over fourth quarter) & 2.8 & 3.7 & 3.5 & 3.3 & 3.2 & 3.1 \\
\hline
\end{tabular}

Sources: FY 2004 Budget of the U.S. Government (February 3, 2003); FY 2004 Mid-Session Review, Budget of the U.S. Government, (July 15, 2003); and Fund staff estimates. 


\section{INTERNATIONAL MONETARY FUND}

EXTERNAL

Public Information Notice

RELATIONS

DEPARTMENT

Public Information Notice (PIN) No. 03/96

FOR IMMEDIATE RELEASE

International Monetary Fund

August 5, 2003

$70019^{\text {th }}$ Street, NW

Washington, D. C. 20431 USA

\section{IMF Concludes 2003 Article IV Consultation with the United States}

On July 30, 2003, the Executive Board of the International Monetary Fund (IMF) concluded the Article IV consultation with the United States. ${ }^{1}$

\section{Background}

After experiencing one of the largest stock market declines in the post-war period and then falling into recession in March 2001, the U.S. economy was buffeted by a series of further shocks, including the September 11th attacks, major corporate failures, additional stock price declines, and the war in Iraq. Remarkably, the recession was mild and short-lived, with output declining only $1 / 2$ percent in the first three quarters of 2001.

The recovery, however, has been uneven and sluggish. Growth slowed markedly at the end of 2002 and early 2003, the unemployment rate jumped to just over $61 / 4$ percent in June 2003 , and the output gap has widened. Reflecting these developments, the core CPI inflation rate has drifted downward to under $1 \frac{1}{2}$ percent, a level not seen since the mid-1960s_prompting concern in early 2003 of the risk of deflation.

Both monetary and fiscal policies have provided unprecedented support to the recovery. The target for the federal funds rate was reduced by a cumulative 475 basis points during 2001, a further 50 basis points in November 2002, and an additional 25 basis points in June 2003. The dollar's depreciation since early 2002, the decline in long-term interest rates, and the more recent firming of stock prices have also helped ease financial conditions.

\footnotetext{
${ }^{1}$ Under Article IV of the IMF's Articles of Agreement, the IMF holds bilateral discussions with members, usually every year. A staff team visits the country, collects economic and financial information, and discusses with officials the country's economic developments and policies. On return to headquarters, the staff prepares a report, which forms the basis for discussion by the Executive Board. At the conclusion of the discussion, the Managing Director, as Chairman of the Board, summarizes the views of Executive Directors, and this summary is transmitted to the country's authorities.
} 
On the fiscal front, substantial reductions in income tax rates were legislated in June 2001; March 2002 legislation increased investment incentives and extended unemployment benefits; defense and security-related spending was increased significantly in 2002 and 2003; and substantial additional tax cuts were legislated in May 2003. These measures contributed to a massive shift in the federal government's unified budget balance, from a surplus of $2 \frac{1}{2}$ percent of GDP in FY 2000 (October-September) to a deficit likely to exceed 4 percent of GDP in FY 2003. With the economic slowdown also weighing heavily on revenues at the state and local level, the combined balance of the general government could reach a deficit of 6 percent of GDP in 2003.

Against this background, household demand has remained resilient. Reflecting the effects of low interest rates, the boom in home prices, and strong growth in disposable incomes, both consumption and residential investment have provided valuable support to domestic demand. At the same time, households were able to boost their saving rate-which had fallen to around 2 percent prior to the recession—to around 31/2 percent in early 2003.

By contrast, business fixed investment, which had plummeted from historical highs relative to GDP during 2000-01, has been much weaker than in past recoveries. Business equipment and software purchases had begun to rebound somewhat in the last three quarters of 2002, but have since softened, while a sharp increase in industrial vacancy rates has continued to weigh on nonresidential structures investment.

Nonetheless, productivity growth has remained robust and financial market confidence has improved. This partly reflected aggressive labor shedding in 2002, which helped yield a 2 percent decline in unit labor costs and a $43 / 4$ percent surge in productivity-the fastest annual rate in over 50 years. As a result, profits have begun to recover and the increased risk aversion triggered by accounting scandals and the uncertainty during the buildup to the Iraq war appears to have eased considerably. Reflecting improved confidence, equity markets have rallied since April and bond spreads have narrowed.

However, weak demand abroad and the earlier strength of the U.S. dollar have weighed heavily on the economy. Export volumes began to recover modestly in 2002, but fell again toward the end of the year and in early 2003 and remain at a low ebb. By contrast, import volumes rebounded strongly in 2002, reflecting purchases of consumer goods and industrial supplies. These factors, as well as higher world oil prices, helped to push the current account deficit to a record 5 $1 / 4$ percent of GDP in 2003Q1. With less favorable interest rate differentials and weaker global sentiment toward U.S. equities, private capital inflows fell. Although this was offset by slower investment abroad by U.S. residents and increased purchases of U.S. dollar assets by foreign central banks, the dollar depreciated in nominal effective terms by around 15 percent between February 2002 and June 2003.

The staff projects activity to gather momentum in the latter half of 2003, with GDP growth rising from around $2 \frac{1}{4}$ percent in 2003 to $3 \frac{1}{2}$ percent in 2004 . Consumer sentiment has improved with the quick end to the Iraq war, and household demand would be further supported by additional tax cuts, the rebound in stock prices, low interest rates, and the easing of oil prices. These same factors, as well as strong productivity growth, are also expected to allow profits and business fixed investment to gather strength into 2004. The drag from net exports would wane into 2004, reflecting gradual recoveries abroad and the lagged effects of the dollar's 
- 3 -

depreciation, and the current account deficit would start to narrow somewhat from around 5 percent of GDP in 2003. With economic slack remaining significant, headline CPI inflation is projected to fall to around $1 \frac{1}{4}$ percent in 2004 , before rebounding somewhat as the output gap closes.

\section{Executive Board Assessment}

Executive Directors highlighted the valuable support that the U.S. economy has given to global growth, reflecting the economy's remarkable resilience and flexibility in the face of severe shocks, and the exceptional stimulus provided by U.S. monetary and fiscal policies. Directors welcomed the recent signs that the recovery appears to be gathering momentum, with improved prospects for stronger growth in the second half of 2003 and into 2004. At the same time, however, they noted that the recovery has thus far been uneven, and that downside risks remain. These risks reflect uncertainties regarding the strength of business investment, the extent to which adjustments associated with the unwinding of the equity price bubble have fully run their course, and the support that can be expected from the global environment. Many Directors also pointed to possible developments, especially in the housing market, that might affect the strength of household demand.

Looking ahead, Directors agreed that the long-term growth prospects for the U.S. economy remain strong, supported by its flexibility, which has contributed to high productivity growth in recent years. They stressed, however, that for the economy's full potential to be realized, decisive action will need to be taken over the coming years to re-establish a strong U.S. fiscal position. In particular, they expressed concern that the worsening of the longer-term fiscal position, including as a result of the recent tax cuts, will make it even more difficult to cope with the aging of the baby-boom generation, and will eventually crowd out investment and erode U.S. productivity growth.

Against this backdrop, Directors saw as priority for the U.S. authorities to manage carefully the risks to the recovery, while establishing a credible approach for dealing with the longer-term fiscal problem. They underscored that an effective response to these challenges will also help ensure that the U.S. economy continues to play a key role in supporting sustainable global growth, and avoid placing undue pressure on global saving and interest rates.

Directors commended the Federal Reserve for its strong and proactive response to the economic slowdown. Most Directors saw scope for further easing if disinflationary pressures are not arrested, and welcomed, in this regard, the authorities' readiness to take further action if needed, including by using a broader range of policy instruments. A number of Directors considered that a quantified statement by the Federal Reserve of its medium-term inflation objective could help anchor inflation expectations even more firmly and strengthen policy transparency, especially in the present situation of very low interest rates and concerns about possible, albeit remote, deflation risks. A few other Directors, however, observed that a more specific statement of inflation objectives is unnecessary as a practical matter, given the clear statement of intentions by Federal Reserve officials, and cautioned that a more specific statement of an inflation objective might erode the authorities' credibility in the absence of instruments to achieve with precision a particular inflation target. 
-4 -

Directors considered the depreciation of the dollar during the past year to be consistent with monetary easing and with the longer-term need to bring the U.S. current account deficit to a more sustainable position. Some Directors noted, however, that the impact on the current account could be relatively modest since the dollar had depreciated against the currencies of only a limited set of U.S. trading partners. Directors underscored the importance of continuing to ensure a cooperative approach toward the orderly adjustment of the U.S. current account deficit. This would need to involve disciplined fiscal policies in the United States to help strengthen national saving, as well as strong efforts among U.S. partner countries to promote sustained growth.

Directors considered that the authorities face significant challenges in ensuring the long-term sustainability of the fiscal position. Although the deficit-to-GDP ratio is projected to narrow in coming years, the projections assume a substantial improvement in tax receipts and strict limits on discretionary outlays, both of which would mark a sharp turnaround from recent developments. The risks to the fiscal outlook appear especially worrisome given the significant actuarial deficit arising from the longer-term demographic pressures on the Social Security and Medicare systems.

Against this background, Directors again urged the authorities to establish a credible fiscal framework, with the clear objective of returning the budget to balance, excluding Social Security, over the next five to 10 years. By helping to reduce the debt ratio ahead of impending demographic pressures, this framework would provide room to phase in the reforms that are needed to place retirement and health care systems on a sound financial footing. To help ensure the sizable fiscal adjustment over the medium term, Directors stressed the need to contain spending growth, and they welcomed the authorities' intentions in this regard. They also underscored the importance of carefully reviewing tax priorities, given the considerable uncertainty surrounding the future revenue outlook and path of tax rates. In this context, some Directors specifically recommended measures to increase the tax effort to support the fiscal adjustment. A few Directors encouraged the authorities to consider energy-related taxes, which, in addition to helping to align energy supply and demand and curb emissions, could contribute to strengthening the fiscal position.

Directors welcomed the assessment of the fiscal transparency Reports on Observance of Standards and Codes that the United States sets high-level or best practice standards in most areas of fiscal transparency. However, in some respects-in particular, the extensive use of sunset clauses on tax cuts and the omission of some significant costs from recent budget projections-most Directors noted that fiscal transparency appears to have weakened in recent years. Directors welcomed recent plans to strengthen expenditure discipline and encouraged the authorities to consider further steps toward new fiscal responsibility legislation that would replace and strengthen the Budget Enforcement Act. Moves in this direction would serve to catalyze and sustain political support for the needed fiscal adjustment by providing a suitable framework for disciplining policies, and placing tax and expenditure decisions in the appropriate medium-term context.

Directors urged the authorities to take early steps to strengthen the financial position of the Social Security and Medicare systems. Relatively modest changes, if taken in a timely fashion, could be sufficient to close projected shortfalls in the Social Security system. However, the financial position of the Medicare system is particularly difficult. In light of this, some Directors emphasized that any measures to enrich benefits should be placed in the context of a broad 
-5 -

strategy to deal with the system's longer-term financial problems. A number of Directors also stressed the need to consider the difficult financial situation of the state and local budgets.

Directors welcomed the resilience of the U.S. banking system in the face of the economic slowdown, and noted that banks' balance sheets appear to have held up well. Vigilance will, nevertheless, be needed to ensure that banks are well-positioned to absorb the effects of an eventual turnaround in interest rates or a possible cooling of real estate markets. Although Directors noted that the government-sponsored enterprises do not appear to pose a systemic risk, they urged the authorities to continue to monitor closely their risk management and accounting practices, and to ensure that their disclosure was adequate. A number of Directors saw merit in steps that would further limit these agencies' special status. Some Directors reiterated their encouragement to the United States to undertake a Financial Sector Assessment Program. Directors welcomed the authorities' intensified efforts to combat money laundering and the financing of terrorism, and looked forward to early full compliance with Financial Action Task Force recommendations.

Directors welcomed the considerable progress that has been made toward strengthening the oversight of accounting and corporate governance during the past year. The priority now is to ensure that the responsible agencies are provided with sufficient resources and support to complete the reform agenda, in particular on improving accounting standards, ensuring the independence of corporate boards, and harmonizing U.S. and international accounting standards. Many Directors expressed concern about the significant underfunding of definedbenefit corporate pension plans that has emerged in recent years. They called for a strengthening of the accounting, transparency, and funding of these plans. In the latter case, some Directors particularly pointed to the merit of relaxing tax penalties against contributions to fully funded plans. Some Directors also underscored the importance of carefully reviewing options for strengthening the finances of the Pension Benefit Guaranty Corporation.

Directors called upon the United States to continue to play a leadership role in promoting an open multilateral trade system. They acknowledged that the U.S. authorities have already made useful proposals for moving the Doha Round forward, and looked forward to further concerted efforts to find common ground with partner countries. Going forward, it will also be important to continue to ensure that U.S. efforts to promote bilateral and regional free-trade agreements are complementary to the multilateral approach to liberalization, and designed in a manner that limits trade diversion and administrative complexities. Some Directors also encouraged the authorities to take early action to comply with recent World Trade Organization rulings.

Directors welcomed the U.S. authorities' commitment to boost development assistance, and looked forward to further increases from its still very low level in relation to GNP. Many Directors also saw scope for improving the complementarities between development and trade policies, including by reducing U.S. agricultural subsidies further and lowering non-tariff barriers to imports from developing countries.

Public Information Notices (PINs) are issued, (i) at the request of a member country, following the conclusion of the Article IV consultation for countries seeking to make known the views of the IMF to the public. This action is intended to strengthen IMF surveillance over the economic policies of member countries by increasing the transparency of the IMF's assessment of these policies; and (ii) following policy discussions in the Executive Board at the decision of the Board. The Staff Report for the 2003 Article IV Consultation with the United States is also available. 


\section{Table 1. United States: Selected Economic Indicators}

(Annual change in percent, unless otherwise noted)

\begin{tabular}{|c|c|c|c|c|c|c|c|}
\hline & 1996 & 1997 & 1998 & 1999 & 2000 & 2001 & 2002 \\
\hline \multicolumn{8}{|l|}{ NIPA in constant prices $1 /$} \\
\hline Real GDP & 3.6 & 4.4 & 4.3 & 4.1 & 3.8 & 0.3 & 2.4 \\
\hline Net exports $2 /$ & -0.2 & -0.3 & -1.2 & -1.0 & -0.8 & -0.2 & -0.6 \\
\hline Total domestic demand & 3.7 & 4.7 & 5.4 & 5.0 & 4.4 & 0.4 & 3.0 \\
\hline Final domestic demand & 3.7 & 4.3 & 5.3 & 5.2 & 4.3 & 1.6 & 2.4 \\
\hline Private final consumption & 3.2 & 3.6 & 4.8 & 4.9 & 4.3 & 2.5 & 3.1 \\
\hline Public consumption expenditure & 0.5 & 1.8 & 1.4 & 2.9 & 2.8 & 3.7 & 4.4 \\
\hline Gross fixed domestic investment & 8.4 & 8.8 & 10.2 & 7.9 & 5.5 & -2.7 & -1.8 \\
\hline Private & 9.3 & 9.6 & 11.4 & 7.8 & 6.1 & -3.8 & -3.1 \\
\hline Public & 3.9 & 5.0 & 4.4 & 8.2 & 2.4 & 3.3 & 4.3 \\
\hline Change in business inventories $2 /$ & 0.0 & 0.4 & 0.2 & -0.2 & 0.1 & -1.2 & 0.6 \\
\hline GDP in current prices $1 /$ & 5.6 & 6.5 & 5.6 & 5.6 & 5.9 & 2.6 & 3.6 \\
\hline \multicolumn{8}{|l|}{ Employment and inflation } \\
\hline Unemployment rate (percent) & 5.4 & 4.9 & 4.5 & 4.2 & 4.0 & 4.8 & 5.8 \\
\hline CPI inflation & 2.9 & 2.3 & 1.5 & 2.2 & 3.4 & 2.8 & 1.6 \\
\hline GDP deflator & 1.9 & 1.9 & 1.2 & 1.4 & 2.1 & 2.4 & 1.1 \\
\hline \multicolumn{8}{|l|}{ Financial policy indicators } \\
\hline Unified federal balance (billions of dollars) & -108 & -22 & 69 & 126 & 236 & 127 & -158 \\
\hline In percent of CY GDP & -1.4 & -0.3 & 0.8 & 1.4 & 2.4 & 1.3 & -1.5 \\
\hline Central government balance (NIPA, billions of dollars) & -138 & -48 & 46 & 110 & 207 & 71 & -218 \\
\hline In percent of GDP & -1.8 & -0.6 & 0.5 & 1.2 & 2.1 & 0.7 & -2.1 \\
\hline General government balance (NIPA, billions of dollars) & -191 & -106 & -5 & 43 & 116 & -73 & -393 \\
\hline In percent of GDP & -2.4 & -1.3 & -0.1 & 0.5 & 1.2 & -0.7 & -3.8 \\
\hline Three-month Treasury bill rate & 5.1 & 5.2 & 4.9 & 4.8 & 6.0 & 3.5 & 1.6 \\
\hline Ten-year government bond rate & 6.4 & 6.4 & 5.3 & 5.6 & 6.0 & 5.0 & 4.6 \\
\hline \multicolumn{8}{|l|}{ Balance of payments } \\
\hline Current account balance (billions of dollars) & -118 & -128 & -205 & -291 & -411 & -394 & -481 \\
\hline In percent of GDP & -1.5 & -1.5 & -2.3 & -3.1 & -4.2 & -3.9 & -4.6 \\
\hline Merchandise trade balance (billions of dollars) & -191 & -198 & -247 & -346 & -452 & -427 & -485 \\
\hline In percent of GDP & -2.4 & -2.4 & -2.8 & -3.7 & -4.6 & -4.2 & -4.6 \\
\hline Export volume (NIPA, goods and services) & 8.2 & 12.3 & 2.1 & 3.4 & 9.7 & -5.4 & -1.6 \\
\hline Import volume (NIPA, goods and services) & 8.6 & 13.7 & 11.8 & 10.9 & 13.2 & -2.9 & 3.7 \\
\hline Invisibles (billions of dollars) & -118 & -128 & 42 & 55 & 41 & 33 & 4 \\
\hline In percent of GDP & -1.5 & -1.5 & 0.5 & 0.6 & 0.4 & 0.3 & 0.0 \\
\hline \multicolumn{8}{|l|}{ Saving and investment (as a share of GDP) } \\
\hline Gross national saving & 17.3 & 18.1 & 18.8 & 18.4 & 18.4 & 16.5 & 15.0 \\
\hline General government & 0.7 & 1.9 & 3.1 & 3.8 & 4.4 & 2.6 & -0.2 \\
\hline Private & 16.5 & 16.2 & 15.7 & 14.6 & 14.0 & 13.9 & 15.2 \\
\hline Personal & 3.5 & 3.0 & 3.4 & 1.9 & 2.1 & 1.7 & 2.7 \\
\hline Business & 13.0 & 13.1 & 12.2 & 12.7 & 11.9 & 12.2 & 12.5 \\
\hline Gross domestic investment & 19.1 & 19.9 & 20.7 & 20.9 & 21.1 & 19.1 & 18.6 \\
\hline
\end{tabular}

Source: Haver Analytics and IMF staff estimates.

1/ National accounts data as available at the time of the July 30, 2003 Executive Board discussion.

2/ Contribution to growth. 